\title{
Skupština u Kozini Političkoga društva Edinost 10. srpnja 1922. i namjera obnove rada Političkoga društva za Hrvate i Slovence u Istri u listopadu 1922.
}

\author{
Prethodno priopćenje | Preliminary communication \\ UDK 061.2:32>(497.57)"1922" \\ 94(497.57):323.1>"1922" \\ DOI \\ Primljeno | Received: 2. X. 2019.
}

\begin{abstract}
Izvadak
Nakon dolaska Istre, Trsta i Goričke u sastav Kraljevine Italije, ostvarenje političke sloge bilo je dominantno pitanje slovenskih i hrvatskih političkih radnika. Aktivnost Političkoga društva Edinost iz Trsta kreće prema obnavljanju i objedinjavanju njegova rada te pokretanju jedinstvenoga političkog djelovanja na prostoru koji se našao pod Italijom. Razlike u nazorima između liberala i kršćanskih socijalista su se u jedinstvenom društvu zadržale, ali su se ipak povezali zbog sveukupnih nacionalnih interesa. U središtu interesa rada su reakcije povodom konstituiranja novoga Istarskog pododbora na skupštini u Kozini 10. srpnja 1922. te pokušaj istarskih kršćanskih socijalista da na skupštini u Trstu 12. listopada 1922. obnove Političko društvo za Hrvate i Slovence u Istri, koje je izbijanjem Svjetskoga rata bilo obustavilo rad.
\end{abstract}

\section{Excerpt}

After the accession of Istria, Trieste and Gorizia to the Kingdom of Italy, the achievement of political unity was a dominant issue within Slovenian and Croatian political workers. The activity of the Political Society 'Edinost' from Trieste moved towards the renewal and unification of its work and the initiation of a unique political activity in the area that found itself ruled by Italy. The differences in views between liberals and Christian socialists persisted in a unified society, but were linked nevertheless because of overall national interests. The focus of the paper is on the reactions on the constitution of the new Istrian subcommittee at the Kozina assembly 
on 10 July 1922, and the attempt on 12 October 1922 at the assembly in Trieste by the Istrian Christian Socialists to renew the Political Society for Croats and Slovenes in Istria, whose work was suspended because of the Great War.

Ključne riječi: koledar Istranin, Pučki prijatelj, Učiteljski list, Edinost, Goriška straža, Božo Milanović, Virgilij Šček, Josip Wilfan, Ulikse Stanger, Političko društvo za Hrvate i Slovence u Istri

Key words: calendar Istranin, Pučki prijatelj, Učiteljski list, Edinost, Goriška straža, Božo Milanović, Virgilij Šček, Josip Wilfan, Ulikse Stanger, Political Society for Croats and Slovenes in Istria

\section{Uvodne napomene}

Na prijelomu XIX. i XX. stoljeća nacionalni pokret Hrvata i Slovenaca u Istri ulazi u razdoblje stagnacije. Pokazatelj su rezultati državnih, zemaljskih i općinskih izbora, ali i socijalno-gospodarski položaj seljaštva, koje je bilo glavni oslonac nacionalnom vodstvu pokreta. Premda rezultati državnih izbora iz 1897. i 1901. ukazuju na slabljenje hrvatskih i slovenskih pozicija u Istri i Trstu, a jačanje pozicija talijanskih liberala, treba napomenuti da se slovenski izborni neuspjeh u trećem izbornom kotaru u Trstu 1897. i 1901. ponajprije dogodio zbog prekida apstinencije Talijanske liberalne stranke. Nakon izbora jačao je i talijanski iredentizam, koji će u Kraljevini Italiji početkom XX. stoljeća stjecati sve veću afirmaciju, a njegov će utjecaj prodirati među Talijane u Austro-Ugarskoj. Političko društvo Edinost - u okviru kojega su djelovali istarski narodnjaci - sagledavalo je izlaz iz kriznoga stanja prvenstveno u Sjedinjenoj Sloveniji. Istodobno su se na prijelomu stoljeća u Markgrofoviji Istri odvijale važne aktivnosti istarskih narodnjaka na pravno-političkom, gospodarskom i kulturnom području, koje će voditi prevladavanju poteškoća. Nekako u isto vrijeme utemeljit će se politička organizacija istarskih narodnjaka - Političko društvo za Hrvate i Slovence u Istri sa sjedištem u Pazinu 1902. - ali i gospodarska organizacija - Gospodarska sveza za Istru u Puli 1903. Gospodarske organizacije, pogotovo značajne posujilnice, oslobađale su seljaštvo zaduženosti i stvarale uvjete za njegovu gospodarsku neovisnost te mu omogućile izražavanje vlastite volje na raznim političkim izborima. Utemeljenjem i djelovanjem političke organizacije istarskih narodnjaka, utemeljenjem i djelovanjem zadružnih organizacija i radom kulturnih institucija, uz neizosta- 
vnu demokratizaciju izbornoga zakonodavstva za bečki parlament, kad je na temelju općega izbornog prava glasa Hrvatsko-slovenska narodna stranka u Istri na državnim izborima 1907. ostvarila uspjeh, poteškoće u razvoju pokreta na prijelomu stoljeća bile su prevladane. ${ }^{1}$

U političkom životu Istre krajem XIX. i početkom XX. stoljeća počinju se javljati i nova idejna kretanja kao posljedica novih idejnih previranja u Monarhiji, ali i u ostaloj Europi. Odnos prema nacionalno-liberalnoj i kršćansko-socijalnoj struji unutar Narodne stranke, odnos prema katoličkom i socijalističkom pokretu posebno zaokuplja vodstvo istarskih narodnjaka i to u smislu čuvanja jedinstva stranke i nacionalnih redova. Krajem XIX. i početkom XX. stoljeća na slabljenje pozicija istarskih narodnjaka utjecat će istrijanski pokret Ivana Krstića, koji je novčano potpomagala Talijanska liberalna stranka. ${ }^{2}$

Istarski su narodnjaci podupirali novu izbornu reformu za bečki parlament, zalagali su se za opće izborno pravo te su od novoga izbornog reda očekivali jačanje svojih pozicija u Carevinskom vijeću. Političko društvo za Hrvate i Slovence u Istri održalo je širom Istre 1906. i 1907. niz javnih sastanaka i skupština na kojima se podržavala nova izborna reforma za bečki parlament. Međutim, težnje će narodnjaka temeljem uspješnih izbornih rezultata 1907. istodobno ići i prema Istarskom saboru, prema reformi zemaljskoga izbornog reda, koja bi im omogućila veći utjecaj u autonomnim upravnim tijelima pokrajine, pa i ostvarenje ravnopravnosti s talijanskim liberalima. Potonji su pod pritiskom bečke vlade, kao i hrvatski narodnjaci, u ožujku 1908. prihvatili djelomičnu demokratizaciju zemaljskoga izbornog sustava, a novom je izbornom geometrijom talijanskim liberalima u Saboru i dalje bila osigurana prevlast. Od hrvatsko-slovenskih predstavnika protiv nove izborne reforme bili su Vjekoslav Spinčić i Matko Mandić, a od tali-

1 Kada Janez Kramar prikazuje nastanak i utemeljenje Političkoga društva za Hrvate i Slovence u Istri 1902., odnosno odvajanje od Političkoga društva Edinost, spominje da su istarski Hrvati prigovarali Edinosti na prevelikom zauzimanju za Sjedinjenu Sloveniju te da su liberali u Trstu i okolici te sjevernoj Istri imali prevladavajući utjecaj. Navodi da su istarski Hrvati objašnjavali slabe izborne rezultate na državnim izborima u siječnju 1901. neuspješnim radom Edinosti u Istri. Božo Milanović piše kako Političko društvo Edinost nije moglo iz Trsta uspješno obavljati političko djelovanje u Istri „gdje su bile drukčije prilike i osobe“ pa su istarski Hrvati 7. svibnja 1902. utemeljili svoje Političko društvo za Hrvate i Slovence u Istri. Utemeljenjem samostalne političke organizacije istarskih narodnjaka neće biti prekinute veze s Političkim društvom Edinost. Među voditeljima jednoga i drugoga društva javljat će se nesuglasice, između društava događali su se i sporovi, ali jednako se tako - kada se radilo o raznim pitanjima - nastavilo zajednički nastupati i djelovati. Božo Milanović, Hrvatski narodni preporod u Istri, II, Pazin 1973., 425; Janez Kramar, Narodna prebuja istrskih Slovencev, Koper 1991., 57-63, 66, 135-139, 144-146, 148-153, 331-334; Salvator Žitko, „Slovensko-hrvaški politični odnosi v Istri v času ustavne dobe 1861-1914“, Annales, 12, 1, 2002., $45-46$.

2 Stipan Trogrlić, „Istrijanski pokret’ Ivana Krstića“, Istarska Danica 2003., Pazin 2002., 156-159. 
janskih liberala Felice Bennati, vođa liberalne većine u Istarskom saboru. ${ }^{3}$

O donošenju nove zemaljske izborne reforme razgovaralo se na sjednicama pouzdanika Hrvatsko-slovenske narodne stranke, odnosno na sastancima Političkoga društva za Hrvate i Slovence u Istri. Jedinstvenoga mišljenja nije bilo. Vjekoslav Spinčić isticao je opasnost od majorizacije, a Đuro Červar je upozoravao na apatiju koja bi mogla nastati u narodu prihvaćanjem nove izborne osnove, ali i na mogućnost razdora u stranci, pogotovo na mogući sukob kršćanskih socijalista i liberala. Dinko Trinajstić branio je novu izbornu osnovu. Ustvrdio je da se po dotadašnjem izbornom redu položaj Hrvata i Slovenaca ne bi desetljećima mogao poboljšati i kako se borba vodi već gotovo trideset godina, a narod ne vidi uspjeha. Povrh toga, u narodu je započela svoju aktivnost kršćansko-socijalna strana, pa tako prijeti opasnost da već kod idućih izbora neće biti kompaktnosti. Tvrdio je da su garancije koje se daju novom izbornom osnovom dobre, a da se nakon dvije godine može zahtijevati novi izborni red. Novom izbornom osnovom mogu se tražiti potrebna poboljšanja za narod u pregovorima s talijanskom stranom ili ne odobriti ništa i onemogućiti djelovanje Sabora: „Mi dakle moramo već u prvom saborisanju osigurati naše potrebe, koje Talijani moraju odobriti, inače onemogućimo i njima.“ Matko Laginja je pak, tumačio da će novom reformom borba u Saboru biti olakšana, da se od vlade tražilo ukidanje kurijalnoga sustava, ali uzalud, te da se sada Talijanima priznaje šest glasova većine i to ne za stalno jer će se poslije tražiti ukidanje kurije veleposjeda i trgovačke komore. Sada je snižen i cenzus, a i razdioba izbornih kotareva je bolja: „Mi se moramo na dvije strane boriti:

3 Po sporazumu Hrvati i Slovenci mogu povećati broj zastupnika u Saboru na 19, od ukupno 47. U tih 47 uključena su i tri istarska biskupa kao virilisti. Po kurijama bilo je predviđeno: 5 predstavnika velikoga zemljišnog posjeda, 2 predstavnika trgovačko-obrtničke komore, 14 predstavnika gradova, trgovišta i obrtnih mjesta, 15 predstavnika seoskih općina i 8 predstavnika općega razreda. Od 19 hrvatskoslovenskih predstavnika, 3 se odnose na kuriju gradova, 12 na kuriju seoskih općina i 4 na kuriju općega razreda, u kojoj su imali pravo glasa muškarci s navršene 24 godine. Zemaljski odbor, kao upravni i izvršni organ zemaljskoga zastupstva, sastojat će se od 5 predstavnika: jednoga će birati veliki zemljišni posjed, dvojicu će birati gradovi, trgovišta, obrtna mjesta te trgovačko-obrtnička komora, a dvojicu će birati seoske izvanjske općine. Od 5 prisjednika za Hrvate i Slovence predviđena su dvojica, koja se biraju u seoskim općinama. Određena su bila i jamstva za manjinu, zbog mogućega preglasavanja. Za odluke od određene važnosti u Saboru moraju biti prisutna 32 člana, od njih najmanje 7 slavenskih predstavnika, kada su - kao što je bilo uobičajeno - nedostajali istarski biskupi. U Zemaljskom odboru za pravovaljanost odluke trebali su, uza zemaljskoga kapetana ili njegova zamjenika, biti prisutna najmanje tri člana, od kojih je jedan morao biti od predstavnika gradova, dakle Talijan, a drugi od predstavnika seoskih općina, dakle Slaven. Talijanski povjesničar Bernardo Benussi promatra jamstva za manjinu kao ustupak carskokraljevske vlade Slavenima, koji su uvijek mogli blokirati budući rad Sabora, a svojim privilegiranim glasom služiti se kao sredstvom ucjene. Dragovan Šepić, „Politika »narodnog mira« u Istri 1908.-1913.“, Anali Jadranskog instituta, III, 1961., 69-95; Bernardo Benussi, L' Istria nei suoi due millenni di storia, Collana degli Atti 14, Rovigno 1997., 599-600; isti, Povijest Pule u svjetlu municipalnih ustanova do 1918. godine, Pula 2002., 618-622. 
sa Talijanima i sa vladom s druge strane. Ako Talijani budu i dalje perfidni, dugo će proći dok se vlada više njima približi. Prigovor da se ovo vodilo tajno, ukoliko je istinit, opravdava, da ovakve poslove treba voditi tajno. On je za sporazum, i pada s njim.“ Vjekoslav Spinčić bio je protivan tom kompromisu jer da se ne smiju dati majorizirati, a to će svakako biti u odnosu 19 slavenskih prema 25 talijanskih zastupnika. Jamstva, kad bi i pristao na novu izbornu osnovu, ne smatra dovoljnim: „Misli da usljed nedaleke promjene na prijestolju i usljed nedalekog posvemašnjeg ojačanja njemačko kršćansko socijalne stranke da bismo u dogledno vrijeme mogli dobiti bolje uvjete nego su sadanji. A do promjene izbornog reda mora doći.“”

Matko Laginja bio je zagovornik „politike narodnoga mira“, koju je potaknula bečka vlada i koja je trebala ostvariti suradnju i sporazum između Talijanske liberalne stranke i Hrvatsko-slovenske narodne stranke. Izborni rezultati za Istarski sabor koji su održani u listopadu i studenom 1908. išli su u prilog Laginjinih hrvatsko-slovenskih kritičara. Pula je, naime, sa svojom bližom okolicom podijeljena u tri izborna kotara, od kojih je treći, koji se odnosio na gradsku okolicu, bio predviđen novom izbornom reformom za hrvatskoga predstavnika. Tu je umjesto Matka Laginje izabran liberal Carlo Frank pa je Hrvatsko-slovenska narodna stranka umjesto 19 osvojila 18 mandata. Dolazile su primjedbe zašto se uopće pregovaralo s liberalima, kojima se ne može vjerovati. Politika narodnoga mira nije ostvarila očekivano i unutar Političkoga društva za Hrvate i Slovence u Istri dolazi do previranja te izraženoga nezadovoljstva jer ravnopravnost s talijanskim liberalima u Saboru i Zemaljskom odboru, u autonomnim upravnim tijelima, nije postignuta. Unatoč pregovorima i nakon 1908. s predstavnicima talijanskih liberala o raznim pitanjima - novoj razdiobi općina, općinskim izborima, o jezičnoj ravnopravnosti, o školama, zemaljskom proračunu i općinskim proračunima, financijskim potporama, raznim gospodarskim pitanjima - ravnopravnost Hrvata i Slovenaca, koja je bila cilj Hrvatsko-slovenske narodne stranke, odnosno Političkoga društva za Hrvate i Slovence u Istri, nije postignuta. ${ }^{5}$

4 Vjekoslav Bratulić, „Zapisnici sjednica »Hrvatsko-slovenskog kluba« zastupnika u Istarskom saboru 1901-1909. (nastavak)“, Vjesnik historijskih arhiva u Rijeci i Pazinu, XIV, 1969., 348-384.

5 Od svibanjskih izbora za bečki parlament 1907. pa do 1912. angažirani su zemaljski hrvatsko-slovenski zastupnici oko nove izborne reforme za Sabor donesene 1908. te oko novih zemaljskih izbora. Rade u Saboru, pregovaraju s talijanskim zastupnicima o razdiobi općina te sklapaju sporazum 1909. u vezi sa šestogodišnjim produženjem općinskih izbora, a angažirani su i na popisu stanovništva 1910. Godine 1911. uslijedio je dogovor s talijanskim zastupnicima o davanju potpore za zajam općini Pula, zatim onaj o odobrenju proračuna hrvatsko-slovenskim i talijanskim općinama te dogovor o petogodišnjem razdoblju 
Voditelji Političkoga društva - koji su ujedno bili i zemaljski zastupnici - u svojim aktivnostima nastupali su i u jednoj i u drugoj ulozi. Njihova aktivnost kao zemaljskih zastupnika ne može se promatrati odvojeno od njihove aktivnosti kao predstavnika Političkoga društva - ta se aktivnost često preklapala ili podudarala. Tako u diskusijama vođenim o novoj izbornoj reformi za Sabor zemaljski zastupnici predstavljaju Političko društvo koje je bilo vodstvo Narodne stranke, ali pripadnici mlađega naraštaja odnose se kritički jer, govorili su, u tim se diskusijama nije konzultiralo šire članstvo, nisu se povodom tih diskusija održavale društvene skupštine i nisu se održavale sjednice Odbora. Ipak, ocjena nezadovoljnih kritičara iznesena u predstavci Političkom društvu donesenoj u Voloskom 6. siječnja 1912., a objavljenoj u Riečkom novom listu od 14. siječnja 1912., kako „društvo živi u mrtvilu već više godina“, pretjerana je, ${ }^{6}$ samim tim jer su kandidati Političkoga društva za Hrvate i Slovence u Istri Mandić, Laginja i Spinčić izabrani na državnim izborima prethodne 1911., kao i uspješne 1907. Kritičan je i Božo Milanović kada navodi da je tek nakon skupština u Voloskom i Opatiji u veljači 1912. te u Puli u lipnju 1912. Političko društvo nastavilo sa svojim redovitim djelovanjem i naziva to „novim djelovanjem“?

Osim izraženoga nezadovoljstva novom izbornom reformom za Sabor, što je otežavalo rad političke organizacije, unutar Hrvatsko-slovenske narodne stranke, unutar nacionalnih redova, u godinama pred Svjetski rat sve više do izražaja dolaze i idejni sukobi koji su također usporavali rad. Dok je na prijelomu stoljeća riječ o zastoju nacionalnoga pokreta koji je uspješno prevladan, u godinama su se pred rat izrazila idejna previranja, ali će i ona biti prevladana. Razlike u nazorima između kršćansko-socijalne i nacionalno-liberalne struje javljaju se među gimnazijalcima, sveučilištarcima i

za uređenje školskoga pitanja. U svim tim pregovorima pa i sporazumima sudjeluju Namjesništvo u Trstu i vlade u Beču. Božo Milanović piše da se u stvarnosti u tim pregovorima talijanski zastupnici i vlasti u Beču nisu dogovarali s Političkim društvom već s hrvatskim i slovenskim zemaljskim zastupnicima, tako da je Političko društvo nakon izbora 1907. „ostalo u pozadini i zapušteno“, iako je ono kandidiralo pojedince za svibanjske izbore. Šepić, „Politika »narodnog mira« u Istri 1908.-1913.“, 89-121; Milanović, Hrvatski narodni preporod u Istri, II, 426-427.

6 Hrvatsko-slovenski nacionalni prvaci - zemaljski zastupnici, neki i zastupnici u bečkom parlamentu, ujedno i predstavnici Političkoga društva - djelovali su čitav niz godina u raznim područjima: političkom, pravnom, gospodarskom, kulturnom... Bili su tako angažirani i oko dugogodišnjega aktualnog pitanja liturgijskoga jezika. Političko društvo redovito se bavilo tim pitanjem na raznim sastancima i skupštinama, tako je u Pazinu održana važna skupština 19. prosinca 1909. Nakon poslanice tršćansko-koparskoga biskupa Franje Nagla od 18. listopada 1909. dolazi do reakcija na Krasu i u središnjoj Istri, do napuštanja crkava tijekom misnoga obreda, a Političko društvo je povodom toga odlučilo reagirati sazivom skupštine na kojoj se okupilo više od 1000 ljudi. Nakon skupštine dolazi do razmjene pisama između biskupa Nagla i potpredsjednika Političkoga društva Šime Kurelića s izraženim suprotstavljenim stajalištima i tumačenjima. V. S. [Vjekoslav Spinčić], Slavensko bogoslužje u Istri, Pula 1913., 193-259.

7 Milanović, Hrvatski narodni preporod u Istri, II, 428-431. 
učiteljima, npr. oko pitanja utemeljenja konvikta u Pazinu, poslije sjemeništa. ${ }^{8}$ Po jednom sugovorniku Vjekoslava Spinčića, postojale bi unutar Političkoga društva za Hrvate i Slovence u Istri tri struje: stari oko Naše sloge, mladi oko Novoga lista i struja onih oko Pučkoga prïatelja. Na skupštini Političkoga društva u Puli 20. lipnja 1912., po izvješćivanju Naše sloge predsjednik Matko Mandić između ostalog navodi da među Hrvatima i Slovencima u Istri nema stranaka, „nego u novije doba su se pojavile samo struje, većinom osobnih načela, radi čega je i bio na zadnjoj skupštini izabran posebni odbor, da te struje izgladi, složi. Ističe važnost današnje skupštine, koja ima da svakoj struji izbije oružje iz ruke te pravi u buduće smetnje u našim redovima. Naš program - veli - jest samo hrvatski, program Dobrile, Vitezića i njihovih sumišljenika. Obzirom na naš težki položaj u Istri, treba da ne stane svakog nesporazumka i ni jednoj struji dopustiti, da još više oteščava i izrabljuje taj položaj, nego moramo svi složno nastupati, te zastupati stari naš program, koji je samo hrvatski.“ Za predsjednika novoga Odbora Političkoga društva izabran je Dinko Trinajstić, a odbornicima su imenovani Matko Laginja, Ivan Zuccon, Ivan Poščić, Josip Stihović i Josip Ribarić. Među odbornicima su svećenstvu, pored Matka Mandića, pripadali Josip Grašić, Šime Červar i Josip Pavačić. ${ }^{9}$

Idejne su razlike trenutno prevladane, a neposredna su posljedica previranja unutar Hrvatsko-slovenske narodne stranke bila nova pravila Političkoga društva iz 1913., koja utvrđuju demokratizaciju društva. ${ }^{10}$ To se može zamijetiti uspoređujući neke članke pravila iz 1902. s člancima pravila iz 1913. U drugom članku pravila iz 1913. stoji: „Svrha je društva buditi i širiti narodnu svijest među Hrvatima i Slovencima u Istri, te braniti i promicati njihove političke, prosvjetne i gospodarstvene probitke i prava u svakoj struci javnog života. Društvo nije vjersko, ali, u koliko to utječe u njegov djelokrug, stoji na pozitivnim kršćanskim načelima.“ Međutim, u pravilima iz 1902. ova se druga rečenica, odnosno tvrdnja, ne nalazi. Jednako

8 Opširnije o toj tematici: Vjekoslav Bratulić, „Političke stranke u Istri za vrijeme narodnog preporoda“, Hrvatski narodni preporod u Dalmaciji i Istri, ur. Jakša Ravlić, Zagreb 1969., 313-317, 332; Stipan Trogrlić, „Katolička crkva u Istri u nacionalno-političkim i idejnim previranjima 1900.-1914.“, Časopis za suvremenu povijest, 28, 3, 1996., 283-302; isti, „Hrvatski katolički pokret u Istri (1907.-1914.)“, Nova Istra, II, VI, 3, 1997., 193-200; isti, „Pazin i Pazinština - središte i žarište Hrvatskog katoličkog pokreta u Istri“, Hrvatska čitaonica u Pazinu, gl. ur. Josip Šiklić, Pazin 1999., 255-274; Milanović, Hrvatski narodni preporod u Istri, II, 375-380, 385-395, 446-448.

9 „Glavna skupština političkog društva za Hrvate i Slovence u Istri“, Naša sloga, 27. lipnja 1912.; Željko Klaić, „Prilog polemici o uspostavljanju Carske kraljevske učiteljske škole u Kastvu“, Zbornik Kastavštine, XVII, 2009., 40-52.

10 Pravila 'Političkoga društva za Hrvate i Slovence u Istri' u Pazinu, Pazin 1913., 1-8. Pravila su pisana hrvatskim i slovenskim jezikom. 
tako, članak 23. iz 1913. navodi kako se društvene objave, zaključke i oglase obznanjuje preko Naše sloge u Puli i Pučkoga prijatelja u Pazinu. U pravilima iz 1902. Pučki prïatelj se ne spominje, a sada se spominje, što se može objasniti jačanjem kršćanskih socijalista u redovima Narodne stranke. U članku 6. pravila iz 1902. navodi se podjela članova društva „na tri jednakopravna reda“: I., koji plaća 12 kruna godišnje članarine, II., koji plaća 6 kruna, i III., koji plaća 2 krune. U članku 6. pravila iz 1913. navodi se pored tih triju i četvrti red, koji plaća 1 krunu godišnje. ${ }^{11}$

U smislu prevladavanja idejnih sukoba i čuvanja jedinstva stranke često istupaju Matko Laginja, Matko Mandić, Vjekoslav Spinčić, Dinko Trinajstić i drugi prvaci. Vodstvo Narodne stranke, uočavajući idejne razlike i sukobe, pozivat će na jedinstvo nacionalnih redova i u tom smislu nastupati na javnim sastancima i skupštinama, bez obzira na to što se nedoumice i krizni trenuci javljaju i između samih voditelja. Takav nastup nije bio samo običan politički pragmatizam. Između ostaloga, bilo je to iskustvo dugogodišnjega upornoga legitimnog rada, ali i predosjećaj kriznih nadolazećih vremena, vremena izraženih europskih suprotnosti s nejasnim ishodima i rezultatima, a zalažući se i pozivajući na jedinstvo stranke i nacionalnih redova željelo se očuvati teško stečene pozicije $\mathrm{u}$ istarskoj pokrajini.

Zbog izbijanja Svjetskoga rata Političko društvo za Hrvate i Slovence u Istri nije bilo u mogućnosti nastaviti s radom, ali ono se spominje tijekom ratnih godina, kao i u vrijeme prestanka postojanja Monarhije. Kada je 3. studenoga 1918. zaključeno primirje između sila Antante i Austro-Ugarske, Istra i istarski otoci bili su faktično priključeni novoosnovanoj Državi Slovenaca, Hrvata i Srba i nalazili se pod upravom Narodnoga vijeća SHS-a u Zagrebu. Predstavnici istarskih Hrvata u plenumu Vijeća bili su predstavnici Političkoga društva za Hrvate i Slovence u Istri Đuro Červar, Josip Grašić i Šime Kurelić, a po pravu, kao zastupnici u Carevinskom vijeću, Matko Laginja i Vjekoslav Spinčić. U središnjem su odboru Vijeća Istru zastupali Đuro Červar, zamjenik mu je bio Josip Grašić, i Matko Laginja, koji je kasnije bio kooptiran. Narodno je vijeće 29. listopada 1918. izabralo tajnika za Istru i Sloveniju Alberta Kramera, a 31. listopada imenovalo je

11 Željko Klaić, „Političko društvo za Hrvate i Slovence u Istri“, Istarska Danica 2001., Pazin 2000., 84-89. 
Matka Laginju povjerenikom za Istru. Rad i djelovanje Političkoga društva za Hrvate i Slovence u Istri nastojat će se obnoviti u posve drugoj povijesnoj situaciji, u vrijeme vladavine Italije u tadašnjoj Julijskoj krajini, u kontekstu odnosa, sporova i sukobljavanja između nacionalno-liberalne i kršćanskosocijalne struje. ${ }^{12}$

\section{Društveno-političke prilike nakon ulaska Istre, Trsta i Goričke u sastav Kraljevine Italije}

Nakon vojne okupacije Istre, Trsta i Goričke, a potom i njihova ulaska u sastav Kraljevine Italije, zbog toga što je cjelokupna egzistencija hrvatskoga i slovenskoga naroda u tim krajevima došla u pitanje, ostvarenje političke sloge bilo je dominantna zadaća unutar slovenskih i hrvatskih građanskih redova. Aktivnost Političkoga društva Edinost iz Trsta kreće prema obnavljanju i objedinjavanju društvenoga rada te pokretanju jedinstvenoga političkog djelovanja na prostoru koji se našao pod Italijom. U Središnjem odboru ustanovljena su dva odsjeka, jedan za Istru i drugi za Goričku. Kako je na godišnjoj skupštini 3. kolovoza 1919. imenovan novi Odbor, u njemu će se nalaziti i Istrani Ivan Banovac, Eduard Bubinić, Matej Škerbec i Ante Belanić. Središnji odbor Edinosti trebao je zastupati interese slovenskoga i hrvatskoga naroda pred novom vlašću, prosvjedovati protiv progona slavenskoga stanovništva te se boriti za očuvanje njegovih gospodarskih i kulturnih institucija. Razlike u nazorima između liberala i kršćanskih socijalista su se u jedinstvenom društvu zadržale, ali su se oni zbog sveukupnih nacionalnih interesa povezali, svakako i na primjeru zajedničkoga nastupanja na državnim izborima 1921. ${ }^{13}$ Jedinstvo je nakon Svjetskoga rata bilo potrebno također zbog međunarodnih čimbenika koji su odlučivali o razgraničenju između Italije i Kraljevine Srba, Hrvata i Slovenaca, trebalo je pokazati kako je Političko društvo Edinost kompaktno i snažno te da u političkom predstavljanju Slovenci i Hrvati imaju svojega zakonitoga zastupnika. No, bez

12 Ferdo Šišić, Dokumenti o postanku Kraljevine Srba, Hrvata i Slovenaca, Zagreb 1920., 171-175, 213; Bogdan Krizman, „Zapisnici središnjeg odbora 'Narodnog vijeća Slovenaca, Hrvata i Srba' u Zagrebu“, Starine, 48, 1958., 340; Milica Kacin-Wohinz, Narodnoobrambno gibanje primorskih Slovencev v letih 1921-1928, II, Koper 1977., 329; Milanović, Hrvatski narodni preporod u Istri II, 514; Kramar, Narodna prebuja istrskih Slovencev, 153.

13 Vjekoslav Bratulić, „Političke stranke u Istri 1918-1923“, Labinska republika 1921. godine, zbornik radova, 2, ur. Vladislav Brajković i Vjekoslav Bratulić, Rijeka 1972., 169-172, 186-187; Milica Kacin-Wohinz, Primorski Slovenci pod italijansko zasedbo 1918-1921, Maribor 1972., 230, 426; ista, Narodnoobrambno gibanje primorskih Slovencev v letih 1921-1928, I, Koper 1977., 27-43; Željko Klaić, „Matko Laginja i Josip Wilfan nakon Prvoga svjetskog rata“, Zbornik Društva za povjesnicu Klana, 6, Klana 2001., 48-51. 
političkoga i gospodarsko-socijalnoga programa Edinosti nije bilo moguće uspostaviti snažnu i djelotvornu organizaciju.

Sredinom 1920. pojavili su se u okviru Edinosti pokazatelji idejnih razmimoilaženja, suprotnosti između kršćansko-socijalne i nacionalno-liberalne struje, i to s obzirom na program rada i djelovanja. Svećenik Ivan Rejec (Rejc) na sjednici Odbora Edinosti 10. lipnja 1920. predložio je uime kršćanskih socijalista program na kojem bi trebalo raditi. Tumačio je da borba protiv kapitalizma ne može biti monopol socijalista, da im se ta borba ne smije prepustiti. U programu kršćanskih socijalista napominje se da se „ne smije puzati pred komunizmom, nego mu se ima suprotstaviti umno“. Rejec i njegovi istomišljenici podržavali su zahtjeve za autonomijom pokrajine i to takvom autonomijom koja bi sadržavala „nacionalizaciju seljačkog staleža, njegove zemlje i gospodarskog dohotka, zatim nacionalizaciju obrtnog, trgovačkog, radničkog i drugih staleža s njihovim gospodarskim dobrima“. Rejec je zamijetio da se radništvo otuđilo i da bi Političko društvo na njega trebalo poučno djelovati, ne bi li mu pripremilo put za uspješnu organizaciju u nacionalnim redovima. ${ }^{14}$ Nasilja fašista djelovala su na to da se slovenske i hrvatske građanske snage snažnije povežu i liberalno je vodstvo Edinosti u velikoj mjeri popustilo zahtjevima kršćanskih socijalista. Priznali su im pravo na autonomiju u prosvjetnom radu, da mogu imati kršćanska obrazovna društva u kojima mogu odgajati mladež u duhu svojih nazora. Sporazum među strujama dopuštao je socijalistima i autonomiju u organizaciji zadruga i strukovnih saveza. ${ }^{15}$ Također će u uredništvo lista Edinost ući predstavnik kršćanskih socijalista i dopušteno je da se u listu objavi program kakav je predlagao Rejec. ${ }^{16}$ Slovenski su svećenici tako 1920. predložili Političkom društvu Edinost program koji bi trebao odgovarati potrebama i orijentaciji radnih slojeva. Društvo Edinost bilo je suglasno sa širenjem kršćansko-socijalnih programskih načela, ali ih nije priznalo kao društveni program jer bi načela „ločila duhove“, kako je izjavio Edvard Slavik, jedan od prvaka Edinosti, te dodao da „le v megli moremo skupno delati““.17

I glasilo istarskih kršćanskih socijalista Pučki prijatelj, koje je početkom rujna 1919. ponovno započelo izlaziti, dolaskom Istre u sastav Italije teži

14 Bratulić, „Političke stranke u Istri 1918-1923“, 171; Kacin-Wohinz, Narodnoobrambno gibanje primorskih Slovencev v letih 1921-1928, I, 29-32.

15 Kacin-Wohinz, Narodnoobrambno gibanje primorskih Slovencev v letih 1921-1928, I, 32-39.

16 Ista, Primorski Slovenci pod italijansko zasedbo 1918-1921, 242.

17 Ista, Narodnoobrambno gibanje primorskih Slovencev v letih 1921-1928, I, 135-136. 
ostvarenju političke sloge. Izdavači i uredništvo bili su svjesni - kako piše Božo Milanović - da je Pučki prijatelj bio tada jedino istarsko glasilo i da „izlazi u tragično doba našega naroda u Istri“. Zato je glasilo uređivano nestranački. Branilo je nacionalna prava, tješilo progonjene, budilo nadu u bolje dane i davalo upute, a nije vodilo računa o nekadašnjoj podjeli u dvije struje među naobraženim ljudima. Sloga u nacionalnim pitanjima nije bila narušena ni prije rata, ,a u prvo doba poslije rata drugih pitanja osim narodnih nije među nama ni bilo, jer je sam narod bio u pogibli“. ${ }^{18}$ Uredniku Pučkoga prijatelja preporučeno je 1919. izbjegavati pisanje koje bi izazvalo sukob s nacionalno-liberalnom strujom, a uoči državnih izbora 1921. kršćanski socijalisti podržali su predstavnike nacionalno-liberalne struje Josipa Wilfana i Uliksu Stangera kao istarske kandidate. ${ }^{19}$

18 Božo Milanović, Istra u 20. stoljeću. Zabilješke i razmišljanja o proživljenom vremenu, 1, Pazin 1992., 83-84.

19 Isti, Moje uspomene (1900-1976), Pazin 1976., 57-58. Istarski zastupnici u Privremenom narodnom predstavništvu Kraljevine SHS Vjekoslav Spinčić, Ivan Poščić i Matko Laginja primili su spomenicu od 17. studenoga 1919., koju je potpisalo 125 istarskih javnih radnika, a kojom im se prigovaralo zbog sudjelovanja u stranačkim nadmetanjima u državi. Zahtijevalo se da istupe iz stranaka kojima pripadaju, preporučilo im se da budu iznad svih stranačkih sukoba i da oslobođenje Istre može osigurati samo snažna i jedinstvena Jugoslavija. Između ostalih, tu su spomenicu potpisali liberalni prvaci Mirko Vratović i Ivan Zuccon te katolički prvaci Božo Milanović i urednik Pučkoga prijatelja Ante Belanić. Dragovan Šepić, „Privremeno narodno predstavništvo Kraljevstva SHS i jadransko pitanje (1919-1920)“, Anali Jadranskog instituta, IV, 1968., 172. Promišljanja krugova oko Pučkoga prijatelja u vezi prilika u Kraljevini SHS prikazuje jedan osvrt u glasilu povodom političkoga djelovanja Matka Laginje u trenutku izraženih suprotnosti i zaoštravanja u državi, kada se pripremalo donošenje centralističkoga Vidovdanskog ustava. Istodobno se u tadašnjoj političkoj stvarnosti uključuje i jadransko pitanje i odnos prema pregovorima s Italijom. U raspravama oko nacrta budućega ustava sudjelovao je i Matko Laginja. Predstavnici Narodnoga kluba Mate Drinković i Matko Laginja sudjeluju u razgovorima kod Nikole Pašića 10. svibnja 1921. i odmah je objavljena vijest da bi oni mogli napustiti Beograd jer smatraju da ne mogu mnogo učiniti u smislu svojega programa. I zaista, Narodni klub napušta pregovore vezane za donošenje ustava. U svojoj Izjavi ističe da se želi nametnuti „zemlji ustav sredstvom brojne majorizacije, ne obazirući se na stajalište predstavnika hrvatskog naroda“ i da je Klub prisiljen „da dok se ne dodje na već utvrdjeno stanovište sporazuma, koji isključuje majorizaciju Hrvata, porekne, kao što i izričito poriče zakonitost ove skupštine i njezino pravo, da dade ustav punovažan za Hrvatsku i hrvatski narod“. Laginja je istupio iz Ustavnoga odbora uz protucentralističku izjavu u kojoj je naveo: „Dosadašnja centralistička uprava stvorila je nezadovoljstvo Hrvata i Slovenaca, jer i Tirol ima u Austriji veću samoupravu, nego mi Hrvati, koji smo još pod Madjarskom imali zakonom priznati posebni politički teritorij i posebnu narodnost. Mi to danas ne tražimo. I narod i svoj drž. individualitet unosimo u našu državu. Mi hoćemo vlast naroda, široke samouprave. Ako to primite, sudelovat ćemo u radu." Istup Narodnog kluba i Laginjina izjava su uvelike odredili odnos prema njemu tijekom 1921. Reagirao je Pučki prijatelj od 2. lipnja 1921.: „Ali kako je poznato osim radićevaca, koji uopće nisu došli u ustavotvornu skupštinu, sada je izašao iz skupštine i Narodni klub i priključio se radićevcima i frankovcima u njihovom rovarenju protiv narodne skupštine i narodnog jedinstva. (...) Ne možemo pojmiti, kako jedan dr. Laginja može da se priključuje radićevcima i frankovcima, podupirajući ih u njihovim protudržavnim težnjama, kako da smo mi ovde doprineli svoju veliku žrtvu za to, da drugi mogu razarati, što smo mi upravo tom velikom svojom žrtvom pomogli sagraditi.“ Iako je stav prema Laginji u najblažem smislu dvojben, pisanje Pučkoga prijatelja ukazuje kako su se stranačke suprotnosti u Kraljevini SHS oko donošenja Vidovdanskoga ustava jasno zamjećivale među Hrvatima u Kraljevini Italiji. Laginja je bio nezadovoljan. U svom je dnevniku zapisao: „Biti će da je koji zlobnik ili podpuni ignorant opeta štogod nabacio proti meni onomu dobromu i poštenom puku, kao što je neki dan i Pučki prijatelj iz Trsta nešto imao, a ja se nažalost, da ne bude u Talijana veselja ne smijem javno braniti da nisam separatista, a da baš kao Istranin imam teških razloga oponirati vladi naše države kakva je sada.“ Laginja je dodao da je članak „maslo kojeg demokratića“, očito misleći na pripadnike Demokratske stranke, svakako na grupu oko Svetozara Pribićevića, zagovaratelja bezuvjetnoga provođenja centralizma koji bi se ostvario budućim ustavom. Željko Klaić, „Spomenica Matka Laginje od 23. veljače 1921., upućena predsjedniku vlade Nikoli Pašiću“, Zbornik Društva za povjesnicu Klana, 9, Klana 2016., 110-118. 
Međutim, i Pučki prijatelj započet će izražavati nezadovoljstvo zbog nepostojanja sustavnoga i organiziranoga rada, naglašavajući izraženu apatičnost zbog međusobnoga nepovjerenja u zajednički rad. Nezadovoljstvo izražava upravo u trenutku definitivnoga priključenja Julijske krajine početkom 1921. Italiji, naglašavajući potrebu reorganizacije djelovanja i rada. ${ }^{20}$

Političko društvo Edinost održalo je 4. travnja 1921., neposredno pred državne izbore, godišnju skupštinu na kojoj su delegati prihvatili promjenu prvoga članka društvenih pravila iz 1874., koji je kao područje djelovanja određivao tršćansko područje. Sada je član glasio da područje zahvaća „sve Slovence i Hrvate, koji su pripali talijanskom kraljevstvu“, čime je Edinost formalno raširila djelovanje na čitavu Julijsku krajinu. Predsjednik društva ostao je Josip Wilfan, a njegov zamjenik bio je Tršćanin Edvard Slavik. U novom Odboru od Istrana bili su Božo Milanović, Mate Vlasić (Vlašić), Ivan Vivoda i Tomo Šorli. ${ }^{21}$

20 „Dodji u kojegod društvo, pa bilo u gradu ili na selu, i bit će govora o svim mogućim stvarima, ali teško ćeš kada čuti ozbiljan razgovor o tome, što da uradimo onda, kad nam bude stigao glas iz Rima, da su nas priklopili Italiji, da smo hoćeš, ne ćeš moraš državljani kraljevine Italije! Pitaj našeg čovjeka u gradu, pitaj ga na selu, je li je možda barem sam već razmišljao o tome, a bit će ti odgovor u devedeset slučajeva medju stotinom: »E, bome, jesam, ali što hoćeš, kad se drugi ne brinu za to, zašto bi se brinuo ja!« Tako jedan, tako drugi, tako svi. Da, svi znademo, da će doći ono, čemu ne možemo da izbegnemo, svi znademo, da ćemo se naći u položaju, tako teškom, kako nikada još, ali ipak ima u nas toliko bezbrižnosti, toliko nemara, da prepuštamo vremenu, neka radi umesto nas, a mi: što bilo, bilo! (...) Priznajmo, da ima teških greha na nama u ovom pogledu, i to greha tim težih, čim više ima svaki pojedinac medju nama, prema mestu, koje zauzima u našem narodnom društvu, i dužnosti pram ukupnosti. A što da rečemo tekar o onima, koji su primili na sebe zadaću, povereno im od naroda, da upravljaju njegovim stvarima, da ga vode u njegovoj borbi za opstanak?! Bolja prva nego zadnja zamera, i tu treba reći otkriveno, da vidimo toliko nesigurnosti, toliko neodlučnosti, toliko oklevanja i otezanja, da nam je posve razumljiv nehaj i nemar, koji je zavladao medju narodom. (...) Naša se je organizacija upravo u ovom najvažnijem, najkobnijem času pokazala tako nedostatnom, da će trebati silnog rada, ako hoćemo, da će uopće početi delovati, jer sad, priznajmo, ne deluje gotovo nikako. Istina je, da je reorganizacija nemoguća u par dana, u par tedna, ali istotako ne može poricati niko, da bijaše vremena za reorganizaciju kako bijaše potrebe za nju, ali nestajalo je prave volje, jer se je skupoceno vreme gubilo besplodnim razpravama i prepirkama o sitnicama, dok su velike stvari ostajale nerešene ili prepuštene pojedincima, preopterećenim svakojakim poslovima, tako da ne bijaše nikad vremena za najvažnije. Narod sam nije nikada sudelovao, jer se nije ni kušalo pitati ga za njegove mnenje, kamo li da se pritegne radu. I danas evo posledica takva nesmotrena rada. (...) Opomena za to već danas ne fali, a svakim danom bivati će gore. »Roma deliberante Saguntum persit«, i dok bude kod nas većalo o piknjicama na »i« i radilo jedino lepim rečima o »najsvesnijem delu naroda«, o »najprosvetljenijim sinovima domovine«, o »najtežim žrtvama« itd., ove će najteže žrtve zbilja već izgoreti na žrtveniku a najprosvetljeniji sinovi domovine i najsvesniji deo naroda već će kao vrli sinci nove domovine i svesni jugoslovenski Talijanci igrati puškom i devojkama tamo dole gde u Kalabriji ili Siciliji, a mi ovde ćemo samo još čekati, da nas naša vlastita deca isprate do groblja uz svirku one poznate »Va fuori d'Italia, va fuori straniero!« (...) Kako je naš spas u nama samim, tako je i naša propast u nama samim, i ako se sada, u skrajno vreme ne obrgnemo iz našeg nehaja izgibosmo.“ „Prenimo se, inače izgibosmo! Narodu i njegovim vodjama opomena u dvanaesti sat.“, Pučki prijatelj, 6. siječnja 1921. Autor članka ističe latinsku izreku (točnije) Roma deliberante Saguntum periit („Dok je Rim vijećao, Sagunt je pao.“), vezanu za događanja iz Drugoga punskog rata, koja je poprimila opće značenje u smislu kritike dugoga vijećanja i pregovaranja, dok se ne poduzimaju nikakve konkretne akcije koje bi onemogućile rasulo i propadanje neke sredine. Šime Anić - Nikola Klaić - Želimir Domović, Rječnik stranih riječi, Zagreb 2002., 261.

21 „Glavna skupština političkog društva 'Edinost' u Divači, u ponedeljak, 4. travnja, godine 1921.“, Pučki prijatelj, 7. travnja 1921.; Kacin-Wohinz, Narodnoobrambno gibanje primorskih Slovencev v letih 1921-1928, I, 41-43. 
Na državnim izborima u svibnju 1921. izabrani su Josip Wilfan, Karol Podgornik, Virgilij Šček, Josip Lavrenčič i Ulikse Stanger. Nakon izbora kršćanski su socijalisti javno kritizirali vodstvo Edinosti da je krivo za slabe izborne rezultate u Istri i Trstu. Problematizirali su program rada Političkoga društva, a Šček je dokazivao kako je uspjeh u Goričkoj posljedica dublje aktivnosti i širenja kršćansko-socijalnih načela, modernih socijalističkih načela, koja prvo mora prihvatiti mnoštvo radnika, „v razmeroma mali meri naše izobraženstvo, a so šle v kri in meso mnogim inteligentnim kmetom“. Po Ščekovu su mišljenju zbog socijalno-gospodarskoga programa uspjehu u Goričkoj pridonijeli komunisti i socijalisti. Upozorio je također na stranačke tradicije u Goričkoj, gdje se razvoj uvijek temeljio na sučeljavanju stranačkih programa, te da se Političko društvo Edinost ne smije oslanjati na svoju dotadašnju neprogramsku politiku, koja je možda bila dobra za Trst. ${ }^{22}$

U svojem je reagiranju bio oštar i Pučki prijatelj aktualizirajući u prvom redu izborni program: „Na izbore smo pošli, a da nismo ni pitali, kakav je naš izborni program, a da nismo pitali ni za program stranke, pod čijom smo zastavom pristupili izbornim žarama (... “. ${ }^{23}$ Autor članka se osvrće i na istupe Ščeka i Wilfana, objavljene u Edinosti, koji se odnose na „program naše stranke, odnosno našeg parlamentarnog zastupstva“. Prvi zahtijeva izričito socijalno-gospodarski program, dok se drugi poziva na „program konkretnih stečevina“ u prošlosti i na historijsku nadstranačku misiju Političkoga društva Edinost, označujući zahtjev izričitoga socijalno-gospodarskoga programa strančarskim. Šček, s druge strane, pokreće neka programska pitanja, kao pitanje radničke kontrole u industrijskim poduzećima, pitanje kolonata, zadrugarstvo, pitanje općina, pitanje borbe protiv kapitalizma. Wilfan je zauzeo stav da se o takvim pitanjima ne raspravlja javno već jedino u Političkom društvu, dok Šček traži javnu raspravu uz sudjelovanje naroda, a ne samo u najužem krugu Političkoga društva Edinost. ${ }^{24}$

Upravo su izborni rezultati bili poticaj istarskim kršćanskim socijalistima da i oni započnu sa samostalnijim i aktivnijim radom. Božo Milanović

22 Kacin-Wohinz, Narodnoobrambno gibanje primorskih Slovencev v letih 1921-1928, I, 135-137.

23 „.... istotako i naši kandidati, u koliko su se predstavili izbornicima, uz retke su iznimke stupali pred narod s tačnije zacrtanim programom. Ako jesu, bijaše to njihova lična zasnova, jer skupština stranke ili političkog društva ili pouzdanika, na kojoj bi se bio tačno ili barem u glavnim crtama odredio izborni program, ili na kojoj bi bili kandidati izneli takav jedan program, nije se održavala obzirom na prilike, koje su vladale i još danas vladaju u ovim našim zemljama. (...) Jedinstvenog nacrta za smotreni rad na političkom, kulturnom, socijalnom i privrednom polju, i to je baš program, - nismo imali te ga nemamo ni danas.“ „Pred polaskom narodnih poslanika u Rim. Kakav je program našeg narodnog zastupstva?“, Pučki prijatelj, 2. lipnja 1921.

$24 \mathrm{Na}$ ist. mj. 
navodi da je svestrana kritika za loše izborne rezultate bacala krivnju ne samo na fašistički teror nego i na nerad Političkoga društva Edinost. Trebalo je organizirati one seljake koji su pokazivali smisao za politički rad, organizirati rad za stvaranje đačkoga podmlatka, pokretati rad za gospodarski napredak, ali za sve to nije se nitko brinuo. U tom smislu Milanović smatra potrebnim pokretanje inicijative za samostalnijim i intenzivnijim radom za Istru. Kao jedan od četiriju Istrana u Odboru Edinosti pokreće osnivanje Istarskoga pododbora Političkoga društva Edinost. U srpnju 1921. tajnik Edinosti Fortunat Mikuletič saziva skupštinu u Kozini, na kojoj je bilo tridesetak važnijih osoba iz Istre. Ustanovljen je Istarski pododbor, a Milanović je izabran za predsjednika. Na prijedlog Ulikse Stangera za tajnika je postavljen sveučilištarac Mijo Mirković. Milanović je poslije objasnio da je on bio katolik i svećenik pa je trebalo da barem tajnik bude „protivnih načela“. Tako je na početku kratko vrijeme tajnik bio Mirković, a nakon njega je imenovan Antun Iveša. ${ }^{25}$ Milanović će biti predsjednik godinu dana; otvorio je burnu skupštinu u Kozini 10. srpnja 1922., da bi nakon toga 17. srpnja za predsjednika Pododbora bio izabran Mirko Vratović, a Milanović za potpredsjednika. ${ }^{26}$

\section{O programskim smjernicama djelovanja}

Božo Milanović je objašnjavao u svojim tekstovima u Pučkom prijatelju kako je zamišljao politički rad i djelovanje. U srpnju i rujnu 1921. u glasilu izlaze članci o pojmu, smislu, značenju te djelovanju organizacije, kakvih sve tipova organizacija ima te kakav duh mora vladati u njoj, zatim kako se vode sjednice i skupštine. Stavlja u prvi plan organizaciju kada je riječ o postizanju nacionalno-političkih, gospodarskih i kulturnih ciljeva. Tek u svom posljednjem tekstu u Pučkom prïatelju od 8. rujna 1921., u kojem također raspravlja o smislu i značenju političke organizacije, autor se potpisuje inicijalima B. M., što je nedvojbeno Božo Milanović. ${ }^{27}$

Milanović tako konstatira da su Hrvati i Slovenci u Istri politički razmjerno slabo organizirani. Nije se prije ni osjećala potreba za tim jer su

\footnotetext{
25 Milanović, Hrvatski narodni preporod, II, 506-508; isti, Istra u 20. stoljeću, 1, 127-128.

26 „Novi odbor Pododbora za Istru“, Pučki prijatelj, 20. srpnja 1922.

27 „U organizaciji je naš spas!“, Pučki prijatelj, 21. srpnja 1921.; „U organizaciji je naš spas!“, Pučki prijatelj, 28. srpnja 1921.; „U organizaciji bit će naš spas!“, Pučki prijatelj, 1. rujna 1921.; B. M. [Božo Milanović], „U organizaciji bit će naš spas!“, Pučki prijatelj, 8. rujna 1921.
} 
imali u svakoj općini više pripadnika inteligencije, u prvom redu svećenika i učitelja, koji su skrbili za političko djelovanje. No, protivnici sada sustavno nastoje pomoću fašizma protjerati zadnje ostatke inteligencije, stoga njezino djelovanje mora nadomjestiti čvrsta politička organizacija. Gospodarska organizacija je trenutno najvažnija, dapače temelj i uvjet političkoj. Prije rata počelo se organizirati na gospodarskom polju i osnovan je značajan broj zadruga, posujilnica, ali je to većinom propalo. O gospodarskoj organizaciji trebaju razgovarati i vijećati oni ljudi koji su već dotad na tom polju radili i stekli iskustva. Prosvjetna i kulturna organizacija je, međutim, područje na kojem se prije rata najmanje radilo i zbog toga steklo najmanje iskustva pa predlaže rješenja - oživljavanje čitaonica i omladinskih društava. ${ }^{28}$ Istra je imala predratna iskustva u razvoju omladinskoga pokreta, ${ }^{29}$ a rad s mladeži

28 „Prva naša prosvetna društva bile su čitaonice, ali i te su bile više politične nego kulturne organizacije. Osim čitanja novina nije se tu mnogo njegovala naobrazba i uzgoj članova. Glavna važnost čitaonica bila je u tom, što su po njima dobivali svi naši narodnjaci bez obzira na starost prigodu, da se sastaju i pogovaraju, a koji put da i zapevaju. Tako su osobito u prvo vreme narodnog osvešćivanja bile čitaonice središta narodnog života i najbolja sredstva za probudjivanje narodne svesti. Kako je to prvo »ilirsko« doba narodnog osvešćivanja prolazilo, tako su i čitaonice po Istri gubile svoju važnost i svoj život. Kako smo sada dospeli opet u prilike, u kojima će opet biti najviše potreban rad za održavanje narodne svesti, to će trebati opet oživeti naše stare čitaonice i osnivati nove. Za to vojuju ovi razlozi: 1.) čitaonice su najprimitivnija društva i zato ih je u našim selima najlakše ustanavljati, dapače u mnogo naših sela bit će ona jedina kulturna društva, koja će moći u našim prilikama opstajati; 2.) one se mogu razvijati i onde, gde nema nijedne naše inteligentnije osobe, a to je za naše prilike od nepregledne važnosti; 3.) čitaonice će biti kod nas u Istri najlakše osnivati i uzdržati i zato, što uživaju one u našem puku još uvek svoju časnu tradiciju i veliku popularnost. Mnogo savršenija prosvetna društva jesu omladinska društva, koja okupljaju zajedno samo mladiće više manje iste dobi u svrhu, da se što više naobraze i da se odgajaju u narodnom i moralnom pogledu. Omladinska društva imadu svrhu, da nam odgoje čvrste narodnjake, dobre i stalne moralne značaje i razumne gospodare. Ideja o organizaciji muške mladeži pomoću omladinskih društava niknula je i razvila se četiri godine pre rata u krilu katoličkog pokreta. Kako je i kod seoske mladeži potreban neki svetovni nazor kao temelj naobrazbi, značajnosti i moralnosti uopće (a do toga je bez dvojbe stalo svakom pravom narodnjaku), to se je u omladinskim društvima naglasivala uz narodnu i demokratsku, takodjer verska ideja. Da u buduće ne bude to naglašivanje možda kamen smutnje ili nenaglašivanje na štetu odgoja, trebat će, da se o tome pogovore i slože narodni predstavnici. Taj sporazum ne će biti težak, ako se promisli, da opreke u svetovnom naziranju naših - osobito starijih - narodnih prvaka u Istri nisu nepremostive i da je kod njih ljubav do naroda, a prema tome i do dobrog odgoja naše mladeži kadra koješta i pregoreti.“”,U organizaciji bit će naš spas!“, Pučki prijatelj, 1. rujna 1921.

29 „Oko osnivanja omlad. društava radilo je malne isključivo akademsko društvo »Dobrila«, koje je svojim ustrajnim radom kroz par godina ustanovilo po Istri 16 omladinskih društava. Krasna manifestacija tih organizacija bio je tabor omladinskih društava u Bermu god. 1912., gdje su se sastala omladinska društva pod svojim zastavama iz raznih delova Istre. Divno je bilo pogledati, s kakvim oduševljenjem su se upoznavali naši omladinci iz Alture, Fuškulina, Gologorice, Materade, iz Svetoga Petra u Šumi, Kringe, Berma, Trviža ... (Ovo trotočje ukazuje da je bilo još nekih mjesta u Istri gdje su utemeljena takva društva; op. Ž. K.) (...) Društvo »Dobrila« bilo je priredilo u Pazinu i jedan trodnevni tečaj za odgoj vodja omladinskih društava. Na tom su tečaju bila 42 mladića iz 17 raznih delova Istre (...). Omladinska su društva bila u Istri jedina savršenija prosvetna organizacija. Ratom nam je i to većinom propalo. Još živi omladinsko društvo u Svetom Petru u Šumi, u Kringi i Bermu, u koliko se o društvenom životu u sadanjim fašistovskim prilikama uopće može govoriti.“ B. M. [Božo Milanović], „U organizaciji bit će naš spas!“, Pučki prijatelj, 8. rujna 1921. U jednom članku iz vremena fašističke Italije Milanović piše da bi bilo krivo misliti kako je katolički pokret imao samo vjerski značaj: „To je bio općenito kulturni pokret, koji je išao za tim, da svestrano unaprijedi inteligenciju i narod na temelju kršćanskog svjetovnog nazora." Omladinska, odnosno mladenačka društva ustanovljena su u Bermu, Trvižu, Karojbi, Sv. Petru u Šumi, Kringi, Gologorici, Materadi, Šajinima, Valturi i Fuškulinu. Božo Milanović, „Iz istarske kulturne prošlosti“, Jadranski almanah za leto 1925-1930, ur. Rado Bednarik, Gorica 1930., 53-57. O radu i djelovanju Bože Milanovića: Božo Milanović, „Naše djelovanje pod Italijom“, Istarska Danica 1978., Pazin 
- muškom i ženskom - od izuzetnoga je značaja za nacionalni opstanak. ${ }^{30}$ U zaključivanju navodi da nije potrebno opširno raspravljati kako razvijati političku, gospodarsku i prosvjetnu organizaciju; to treba prepustiti „našem »Političkom društvu« u opće i našem istarskom odseku posebice“, s tim da uvijek treba imati na umu da se može očekivati spas jedino u čvrstoj organizaciji. ${ }^{31}$

Premda se ne može govoriti o nekom cjelovitom programu - niti to prostor u tisku omogućuje - programske smjernice za rad i djelovanje bile su očite. One upućuju na nastavljanje onoga djelovanja istarskih narodnjaka na prijelomu stoljeća, kao i u vremenu pred Svjetski rat, ali upućuju i na djelovanje kršćanskih socijalista u vremenu pred rat, kada su i oni bili dio nacionalnoga pokreta. Iako su se idejne razlike - suprotstavljeni nazori unutar Političkoga društva za Hrvate i Slovence u Istri - pred rat izrazile, Hrvatsko-slovenska narodna stranka je uspjela sačuvati jedinstvo. Milanović je spominjao i uzimao u obzir idejne razlike iz predratnoga vremena te smatrao da se u novim okolnostima o naglašavanju ili nenaglašavanju vjerske ideje u pogledu odgoja trebaju dogovoriti nacionalni predstavnici. Vjerovao je da sporazum neće biti teško ostvariti jer je smatrao da svjetonazorske

1977., 77-81; Antun Hek, „Božo Milanović“, Istarska Danica 1982., Pazin 1981., 28-35; isti, „Životno djelo Bože Milanovića“, Istarska Danica 1991., Pazin 1990., 32-43; Darinko Munić, „Kastav i Kastavština u djelu mons. dr. Bože Milanovića“, Problemi sjevernog Jadrana, 7, 2000., 167-184; Narodi ostaju, režimi se mijenjaju, Zbornik radova o 100. obljetnici rođenja mons. Bože Milanovića (1890.-1980.) sa simpozija održanog u Zagrebu i Pazinu 11.-13. listopada 1990., ur. Ilija Jakovljević, Pazin 2010., 23-254; Aleksandra Golubović - Maja Polić, „Život i filozofska promišljanja Bože Milanovića. U povodu 120. obljetnice rođenja i 30. obljetnice smrti.“, Riječki teološki časopis, 18, 2010., 1, 221-249; Stipan Trogrlić, Mons. Božo Milanović, istarski svećenik (1890.-1980.): crkveno-vjersko i javno-političko djelovanje (dalje: Mons. Božo Milanović, istarski svećenik), Zagreb 2011.; isti, „Nacionalnopreporodni rad mons. Bože Milanovića u tršćanskom razdoblju 1922.-1945.“, Histria, 1, 2011., 137-173; Slaven Bertoša, „Lik i djelo mons. dr. Bože Milanovića (1890.1980.)“, Croatica christiana periodica, 42, 81, 2018., 119-132.

30 „Treba da s radom oko upostave i proširenja omladinske organizacije žilavo nastavimo. Stariji ljudi ne mogu se otresti svojih nazora i pogrešaka. Zato treba započeti s mladeži. Iskustvo, koje smo s omladinskim društvima stekli pre rata, doći će nam sada vrlo dobro. (...) Veoma je važno pitanje i za uzgoj ženske mladeži. Kakva posebna svetovna organizacija naše seoske ženske mladeži ne će u Istri biti u dogledno vreme uopće moguća. Zato ćemo se morati omedjiti na to, da savetujemo naše narodno svećenstvo, neka posvuda, gde je moguće, ustanovi za devojke Marijine kongregacije, koje su svagde pokazale mnogo ploda ne samo u versko-moralnom, nego i u narodnom pogledu. Za odgoj dobrih gazdarica i matera trebat će misliti na jednogodišnje tečajeve za devojke. Tako n. pr. uspevaju krasno slični tečajevi u Tomaju blizu Trsta $u$ »Elizabetišču« u »gospodinjskoj šoli«. Posebnu pažnju trebat će posvetiti raznim pevačkim zborovima, koje moramo ustanavljati po Istri, da se proširi i udomaći naša narodna i umetna pesma." Milanović, „U organizaciji bit će naš spas!“, Pučki prijatelj, 8. rujna 1921.

31 „Danas je vreme organizovanja. Sve se udružuje počev od običnih radnika pa sve do najviših činovnika. Tako je kod svih kulturnih naroda, pa je to najbolji dokaz, da je u organizaciji velika moć. Mi smo maleni narod, dapače smo samo odsečena grana od svoga stabla. Osim toga ide sva državna moć za tim, da nas kao narod istrebi iz naše jadne, patničke, ali nama tako drage Istre. Kako ćemo se dakle uzdržati, ako se ne udružimo složno? (...) Organizacija je spasila malenu Irsku pred silnim Englezem. Organizacija je učinila, da je i malena Srbija dugo odoljevala ponosnoj Austro-Ugarskoj i Nemačkoj. Pomoću organizacije se radništvo cele Evrope vuče iz kapitalističkih pandža. Pomoću organizacije i jedino pomoću nje izvući ćemo se i mi iz ropstva i siromaštva.“ Milanović, „U organizaciji bit će naš spas!“, Pučki prijatelj, 8. rujna 1921. 
opreke među njima - osobito među starijima - nisu nepremostive. U vrijeme kada je pisao nije bilo javnih pokazatelja idejnih neslaganja unutar Istarskoga pododbora Edinosti, niti se u javnosti o tome govorilo. Međutim, narodnjaštvo istarskih kršćanskih socijalista na čelu s Milanovićem - koje je po njima uključivalo i vjersku komponentu - samo nešto manje od godine dana nakon ovoga pisanja, na burnoj skupštini u Kozini 10. srpnja 1922. naći će se pod snažnim napadima i izraženom kritikom. Premda su idejne razlike u nazorima postojale, one su bile u pozadini i nisu se na početku Milanovićeva predsjedanja Pododborom javno izrazile. Te su se razlike pojavile u javnosti najprije na nekim drugim razinama unutar istarskih hrvatskih krugova, primjerice povodom izdavanja koledara Istranin za 1922. Tiskovnoga društva u Pazinu sa suprotstavljenim stavovima i pogledima iznesenim u Učiteljskom listu. Suprotnosti će se u mnogome sve više primjećivati, ali i radikalizirati skupštinom u Kozini 10. srpnja 1922., kao i iznesenim reakcijama nakon održane skupštine.

Pučki prïatelj u rujnu 1921. nastavlja aktualizirati nedovoljnu aktivnost i rad nacionalnih predstavnika, ali kritizira i vlasti u Rimu. One su se izmjenjivale, a na mjestu koje je odlučujuće za Julijsku krajinu ostao je od prvoga dana isti čovjek, komendator Francesco Salata. ${ }^{32}$ Autor članka piše o parlamentarnom povjerenstvu koje je obilazilo novostečena područja o pitanju ratne odštete, ali nije došlo u doticaj s predstavnicima hrvatskoga i slovenskoga naroda. Ukazuje na problem služenja vojne obveze, kao i na nedostatak inteligencije, koja se uglavnom iselila, a ne zna se kakvi su izgledi za otvaranjem učiteljske škole i gimnazije koje bi trebale priskrbiti njezin pomladak, kao ni što se radi na tome da se đaci koji se školuju u Kraljevini SHS nakon škole vrate u Istru. Piše i o poljodjelstvu, o krizi u vinogradarstvu zbog konkurencije talijanskoga vina te problemu novoga poreza, pitajući se što je učinjeno da se spriječi ta katastrofa koja uzrokuje osiromašivanje i iseljavanje seljaka. Na kraju proziva Istarski pododbor Političkoga društva Edinost koji postoji već nekoliko mjeseci „a sada bismo hteli i videti već jednom, da počme $\mathrm{i}$ - raditi!“33

32 Francesco Salata, rodom iz Osora, pri rimskoj je vladi u to vrijeme obnašao dužnost voditelja Središnjega ureda za Nove pokrajine (Ufficio centrale per le Nuove provincie). Kacin-Wohinz, Primorski Slovenci pod italijansko zasedbo 1918-1921, 118, 121-123; ista, Narodnoobrambno gibanje primorskih Slovencev v letih 1921 1928, I, 49, 52, 121, 128, 186-196, 202, 218, 220. Pučki prijatelj piše da "naš narod“ njemu treba zahvaliti za sve zlo koje ga je zadesilo. „Najvažnija naša pitanja. Nekoliko pobude za naš narodni obrambeni rad.“, Pučki prijatelj, 22. rujna 1921.

$33 \mathrm{Na}$ ist. mj. 
Premda se glasilo i prije kritički osvrtalo u pogledu pokretanja nacionalnopolitičkoga rada, sada počinje dominirati promišljanje o tome što će se dogoditi sa stanovništvom u nastupajućem vremenu ako se problemi ne riješe. Smatra da rad nacionalnih prvaka i vodstva treba ojačati i organizirati, i u tom je smislu pisanje nastavak kritičkoga pristupa prema vodstvu političke organizacije iz vremena dok Istarski pododbor još nije bio utemeljen. Tako kritički pristup kršćansko-socijalnoga glasila mogao je poticati obnovu idejnih razlika u nazorima koje su postojale u pozadini. Jedan kasniji podatak iz polemike lista Edinost i Pučkoga prijatelja ukazuje na Milanovićeve poteškoće oko pokretanja rada Pododbora za Istru. Pučki prijatelj od 27. srpnja 1922., nakon održane skupštine u Kozini 10. srpnja, na kojoj se raspravljalo o reorganizaciji Političkoga društva Edinost na teritorijalnoj osnovi (hoće li se pokrenuti samostalna istarska organizacija ili će Istra i dalje biti u okviru tršćanskoga društva Edinost), navodi da za samostalnu istarsku organizaciju govore u prvom redu oni razlozi zbog kojih se Milanović kao ondašnji predsjednik ${ }^{34}$ mnogo trudio svojom inicijativom i bez tuđe pomoći da se Istarski pododbor uopće osnuje. U tome je uspio, ali su se zato baš tršćanski „radnici“ tome mnogo protivili: „Ako treba možemo (se) poslužiti dokazima“. ${ }^{95}$

Obraćanje pisca članka na Istarski pododbor je njegov pokušaj poticanja na pokretanje angažiranijega i intenzivnijega rada, ali uvijek ostaje pitanje koliko se u sustavu nesklonom neslavenskom stanovništvu moglo postići, i to pogotovo u Istri, gdje je fašističko nasilje poprimalo oblike stalnoga stanja.

\section{Josip Wilfan i Virgilij Šček. Utemeljenje Političkoga društva Edinost za Goričku}

Razlike u nazorima iskazale su se u nastupanju izabranih poslanika $\mathrm{u}$ rimskom parlamentu 21. lipnja 1921. Josip Wilfan u svom je prvom govoru - kao što su i njemački poslanici iz Južnoga Tirola namjeravali isposlovati pravo govora na materinskom jeziku jer to im pravo pripada po najnovijim načelima slobode pa tako i po talijanskom zakonu, važećem za francusku manjinu u Val d'Aosti - izjavio da s ostalim poslanicima manjina očekuje od parlamenta izričito priznanje materinskoga jezika za Slovence i

34 Nakon skupštine u Kozini za predsjednika Pododbora izabran je Mirko Vratović.

35 „I mi velimo: Ne tako, braćo!“, Pučki prijatelj, 27. srpnja 1922. Polemika s autorom članka: „Ne tako, bratje!“, Edinost, 23. julija 1922. 
Hrvate. Međutim, puno su više ministar predsjednik Giovanni Giolitti, kao i fašistički predstavnici, bili nezadovoljni onim što je Wilfan dalje govorio. Razložio je u kakvim okolnostima živi slovensko i hrvatsko stanovništvo po dvogodišnjoj okupaciji i optužio vlasti da su od početka zatirale nacionalne slobode, tako da od prvoga dana okupacije „smo dobili zatiralski režim, smo dobili režim, ki je bil surov, krut, v žalostnem nasprotju od tistega, kar je naše ljudstvo pričakovalo od italijanske vojske in naroda, ki je prišel v deželo kot osvoboditelj“, čime je izazvao žestoke reakcije u parlamentu, povike i zahtjeve da prestane govoriti.

Posve je drugačije parlament prihvatio govor Virgilija Ščeka, koji je mijenjao ozračje nakon Wilfanova govora i pokazivao drugu, pomirljivu stranu osjećaja netalijanskoga stanovništva. Premda je Ščekov govor bio taktički drugačiji, u suštini je potvrđivao Wilfanova stajališta. Čitanjem dokumenata iz talijanskoga izvora, čitanjem članaka iz talijanskih časopisa i pastirskoga pisma tršćanskoga biskupa Angela Bartolomasija ${ }^{36}$ o izbornim nasiljima, dokazao je da nepravde i nasilje o kojima je govorio Wilfan nisu izmišljotina. Pozvao je poslanike da ne odobravaju zatvaranje škola, ukidanje autonomije i sprječavanje društvenoga djelovanja samo zato jer se radi o ustanovama građana netalijanske nacionalnosti. Izrazio je vjeru da će talijanski poslanici zajedno sa slavenskima presuđivati o svim odlukama i zakonima temeljem pravičnosti i načelom skladnosti, koje je proglašeno ciljem nedavnoga rata. Na kraju je istaknuo da su Mazzini, Cavour i drugi talijanski velikani sanjali da oba naroda (tj. talijanski i jugoslavenski) budu braća, a ne protivnici. ${ }^{37}$

Različit nastup dvaju slovenskih poslanika u rimskom parlamentu ukazivao je na dva krila u slovenskoj narodnjačkoj organizaciji. Već se sredinom 1920. u Političkom društvu Edinost javlja struja kršćanskih socijalista s Virgilijem Ščekom i Engelbertom Besednjakom, koja je imala pristalice osobito u Goričkoj i u Istri. Suprotno liberalno usmjerenom tršćanskom vodstvu Društva, koje je isključivo inzistiralo na kulturno-jezičnom pitanju, struja kršćanskih socijalista predstavljala je orijentaciju ekonomsko-socijal-

$36 \mathrm{O}$ istupima tršćanskoga biskupa zbog progona hrvatskoga i slovenskoga svećenstva: Fran Barbalić, Vjerska sloboda Hrvata i Slovenaca u Istri, Trstu i Gorici, Zagreb 1931., 57-59; Danilo Klen, Neki dokumenti o svećenstvu u Istri, Zagreb 1955., 15-16, 19; B. M. [Božo Milanović], „Naši biskupi pod Italijom“, Istarska Danica 1978., Pazin 1977., 71; isti, Hrvatski narodni preporod u Istri, II, 533-535; Kacin-Wohinz, Primorski Slovenci pod italijansko zasedbo 1918-1921, 239-240; ista, Narodnoobrambno gibanje primorskih Slovencev v letih 1921-1928, I, 74-75; Trogrlić, Mons. Božo Milanović, istarski svećenik, 61-62.

37 Kacin-Wohinz, Primorski Slovenci pod italijansko zasedbo 1918-1921, 390-391; ista, Narodnoobrambno gibanje primorskih Slovencev v letih 1921-1928, I, 95-105. 
noga programa, koja je trebala biti temelj nacionalnoga očuvanja. Zauzimala se također za umjerenu taktiku u odnosu na vlasti i za povezivanje s Talijanskom pučkom strankom (Partito popolare italiano), od koje se očekivala potpora za pomoć u očuvanju nacionalnih prava. I talijanski su nacionalisti uočavali idejne razlike među strujama, ali su bili svjesni da one ne znače razlike u odnosu na nacionalnost već na različitu taktiku za postizanje istoga cilja. Razlike između tih strana će se pojačavati, kako istupima u parlamentu, tako i u međusobnim odnosima, i pored pitanja programa postat će uzrokom odvajanja goričke organizacije od tršćanskoga društva Edinost. ${ }^{38}$

Liberalno je vodstvo Edinosti smatralo da bi prihvaćanje socijalno-gospodarskoga programa kršćanskih socijalista moglo voditi strančarenju i da bi nacionalni pokret zato mogao oslabjeti. Predlaganjem samo kršćanskosocijalnih načela odbacivalo bi se ljude drugačijih nazora. Zato je predviđalo da će se socijalno-gospodarska pitanja rješavati onoliko brzo koliko će se pojavljivati. Voditelji društva bili su svjesni potrebe rješavanja tih pitanja pa od kršćanskih socijalista nisu zahtijevali odricanje od širenja i provođenja svojih načela. ${ }^{39}$

Nezadovoljstvo stavovima vodstva tršćanskoga Političkog društva s jedne je strane stvaralo težnju za razdiobom društva po pokrajinama, a na drugoj zahtjev za uključivanjem čim većega broja kršćanskih socijalista $u$

38 Ista, Narodnoobrambno gibanje primorskih Slovencev v letih 1921-1928, I, 111.

U drugoj polovici 1921. dolazi do napetosti između Ščeka i Wilfana, odnosno Ščeka i Odbora Edinosti. Šček je dokazivao nesposobnost Odbora i njegovu nezainteresiranost za konkretne probleme, i to s nizom pitanja i inicijativa na koja nije dobio odgovore. Pitao je što je društvo napravilo u vezi s potalijančivanjem mjesnih imena, zabranom izlaganja slovenskih zastava i pjevanja slovenske himne, potporama đacima i njihova studija u Italiji, ustanovljenjem kazališta u Trstu, popisom stanovništva i dr. Želio je znati kako se dijeli potpora istarskim žrtvama, kakvo je stajalište društva o isplati vojne odštete, o vinskoj krizi, o rudarima u Idriji, o kamenolomima i drvnoj industriji, o strukovnim radničkim organizacijama, o pitanju slovenskih sluškinja u Trstu, o općinskoj politici, o plesovima koji su moralno zlo, o kolonima i agrarnoj politici, o razvoju zadruga, o politici iskorištavanja vodene snage. Tražio je statističke podatke o industrijskim poduzećima, nezaposlenosti, izvozu drva, vina i kamena, o novčanim ulozima u Jugoslaviji i drugo. Pored tih brojnih pitanja postavljena su i druga - kako je društvo iskoristilo pismo pape o izbornom nasilju, koje je jedan od najznačajnijih dokumenata u korist nacionalne stvari, kako se ono pobrinulo za pravilno obavješćivanje talijanske javnosti o oštećivanju grobova talijanskih vojnika, koje je talijanski tisak pripisao Slovencima. Zahtijevao je da društvo ustanovi u Rimu informacijski ured i izdaje polumjesečnik za obavješćivanje talijanske javnosti o odnosima u Julijskoj krajini. Također je preko novina Edinost pozivao da se piše u talijanskim novinama jer se ne može očekivati da će talijanska javnost razumjeti položaj Slovenaca u Primorskoj ako o njima ništa ne zna, tim više ako o tome saznaje iz tršćanskih talijanskih nacionalističkih novina. Na postavljena pitanja i prijedloge Ščeku nije nitko odgovarao. Kako piše M. Kacin-Wohinz, Političko društvo Edinost nije bilo tako organizirano i osposobljeno da bi moglo zauzimati stajališta i rješavati niz pitanja iz svih područja života. Načelnoga programa zapravo nije imalo, ni plana rada, odgovarajuće organizacijske strukture ni tehničkih snaga. Drugo je pitanje koliko su vodeći ljudi bili spremni i zainteresirani za rješavanje pojedinih zahtjeva kršćanskih socijalista. Pitanje je i koliko se radilo o namjerno neugodnom ignoriranju Ščekovih napora, koji su u biti potkopavali ulogu dotadašnjih voditelja. Jedno je od ključnih pitanja bilo i raspolaganje financijskim sredstvima. Kršćanski su socijalisti zahtijevali nazočnost u financijskim tijelima i uvid u račune, ali su to tršćanski voditelji odbijali. KacinWohinz, Narodnoobrambno gibanje primorskih Slovencev v letih 1921-1928, I, 143-145. 
središnji Odbor. Razdiobu društva na samostalne odsjeke za Goričku, Trst i Istru uvjetovala bi različita problematika pojedinih pokrajina, kao i predratna tradicija. Kod goričkih kršćanskih socijalista bilo je rašireno uvjerenje da će u samostalnim društvima u Goričkoj i Istri prevladati njihova struja. ${ }^{40}$

O nezainteresiranosti Tršćana za goričke probleme, iz čega je proizišla potreba odvajanja goričkoga društva od tršćanskoga, govorili su Besednjak i Šček na sjednici Jugoslavenske matice u Ljubljani 30. lipnja 1922. Iz njihovih je pritužbi razvidno da spor proizlazi iz različitoga shvaćanja uloge širih narodnih slojeva. Kada su kršćanski socijalisti činili napore za suzbijanjem komunizma u ruralnim područjima kroz osnivanje profesionalnih organizacija i zadružnih ustanova, Tršćani su potiho činili prepreke tom usmjerenju jer je ono moglo pogoditi interese bogatih krugova. Druga je suprotnost između goričkih kršćanskih socijalista i liberala Edinosti, o kojoj je bilo riječi na sjednici Jugoslavenske matice, odnos prema talijanskim strankama, prvenstveno Talijanskoj pučkoj stranci. Gorički su kršćanski socijalisti zagovarali popustljivost, oportunost i povezivanje s njom, dok su liberali Edinosti zastupali apsolutnu nepopustljivost. Kršćanski socijalisti tumačili su da bi nepopustljivost bila učinkovita kada bi na Primorju imali 10 milijuna Jugoslavena te ekonomsku moć, tako da bi lako mogli graditi škole i obnoviti popaljene domove te kada bi bila osigurana perspektiva spajanja s drugim jugoslavenskim narodima. Tumačili su da bi za taktiku približavanja dobili suglasnost i drugih talijanskih stranaka i da je to potrebno jer u Italiji ne vrijede zakoni nego fašističko nasilje podupirano oružništvom i vojskom. Povezivanje s naprednim strankama, pogotovo s Talijanskom pučkom strankom, u Goričkoj bi se pokazalo učinkovitim jer bi se rješavalo pitanje pokrajinske autonomije, a pridobili bi i dio talijanskih glasova te ne bi ovisili samo o slovenskima. Za tu cijenu bi mogli iznuditi određene nacionalne ustupke. Odbor Edinosti nije odobrio prijedlog o sporazumijevanju jer je kršio načelo o nesudjelovanju s talijanskim strankama. Zaključivši kako se Tršćani ne zanimaju za autonomiju Goričke, Besednjak i Šček su započeli s pregovorima, smatrajući to dobrom perspektivom, a Pučka je stranka obećala da će poduprijeti otvaranje slovenskih škola i da će talijanski tisak u Goričkoj prestati s huškanjem. ${ }^{41}$

40 Isto, I, 141.

41 Međutim će daljnje jačanje fašističkoga pritiska, konačno i dolazak fašista na vlast 28. listopada 1922., onemogućiti značaj i utjecaj nefašističkih stranaka pa se tako utjecaj popolara neće moći uzimati u obzir. Povrh toga, gorički su pučani neposredno pred pohodom fašista na Rim započeli odstupati od zahtjeva za autonomijom Julijske krajine, a u prvu fašističku vladu stupili su i poslanici Talijanske pučke stranke. Isto, 
U skladu s težnjom da gorička organizacija bude učinkovitija bez tršćanskih pokrovitelja, gorički je Pododbor Edinosti 24. veljače 1922. zaključio da gorički odsjek društva postane samostalno Političko društvo Edinost sa sjedištem u Gorici. Za usklađivanje rada i rješavanje skupnih pitanja odlučeno je da se ustanovi Narodno vijeće za oba samostalna društva. Prijed$\log$ o osamostaljenju odsjeka iznio je Šček, između ostaloga navodeći da nema ni jednoga Goričana u financijskom odsjeku u Trstu te da će Gorica dobiti novac kada bude imala vlastito društvo. Uslijedile su rasprave povodom aktivnosti Goričana i sazivi skupština tršćanske Edinosti te zahtjevi da Goričani naknadno prouče svoje prijedloge. Na izvanrednoj skupštini Edinosti 1. lipnja istarski su predstavnici naveli da žele ostati u zajednici s tršćanskim društvom. ${ }^{42}$ Goričani ponovno 12. lipnja raspravljaju na skupštini povjerenika goričkoga odsjeka Edinosti i predstavnika drugih organizacija. Donose rezoluciju kojom se odobrava zaključak od 24. veljače da se ustanovi za Goričku samostalno Političko društvo Edinost. Zbog nužne potrebe jedinstva Slavena u Italiji neka se ustanovi za Goričku, Trst i Istru Narodno vijeće kao vrhovno vodstvo za sva nacionalna pitanja. List Edinost u povodu odluke Goričana piše o stranačkom raskolu. ${ }^{43}$

Nakon konačne odluke Goričana sazvana je izvanredna skupština Političkoga društva Edinost iz Trsta za 11. srpnja. Prethodnoga dana, 10. srpnja, u Kozini je istarski odsjek Edinosti nakon izraženih suprotstavljanja izglasao jedinstvo s Trstom, premda su kršćanski socijalisti zahtijevali odvajanje istarskoga odsjeka po goričkom primjeru. U rezoluciji donesenoj na skupštini Edinosti 11. srpnja između ostaloga je navedeno kako Narodno vijeće koje bi bilo sastavljeno od zastupnika samostalnih organizacija ne bi moglo nadomjestiti jedinstveno društvo jer ne bi imalo potrebne neovisnosti, kao ni vlastitoga autoriteta ni moći. ${ }^{44}$ Tako su nakon izdvajanja Goričana u dotadašnjem jedinstvenom društvu ostali tršćanski i istarski

I, $150-151,171-179$

42 Predsjednik Wilfan otvorio je skupštinu izvješćujući o stanju odnosa zemaljskih i središnje organizacije Političkoga društva, pogotovo s obzirom na prijedlog goričkoga odsjeka da se ustanove tri samostojna politička društva za Goričku, Istru i Trst te s obzirom na prijedlog Istrana „naj bi se ohranilo skupno društvo za Trst in Istro“. Glavno je pitanje oko kojega se odvijala rasprava, dijelom također i burna debata, bilo u kakvom obliku i u kakvom opsegu „naj se ohrani tista skupnost glede vrhovnih narodnih interesov, ki jo hočejo varovati tudi tisti, ki sicer zahtevajo popolno osamosvojitev pokrajinskih političnih organizacij: v obliki narodnega sveta, sestavljenega iz odposlancev teh organizacij, ali pa na podlagi dosedanje edinstvene društvene organizacije.“ „Izredni občni zbor političnega društva Edinost“, Edinost, 2. junija 1922 .

43 Kacin-Wohinz, Narodnoobrambno gibanje primorskih Slovencev v letih 1921-1928, I, 153-158.

44 Isto, 158-159. 
odsjek. Za predsjednika tršćanske Edinosti ponovno je izabran Josip Wilfan, a u Odbor je društva izabrano devet Tršćana i devet Istrana. Od Istrana su u Odbor izabrani Mirko Vratović, Ivan Stari, Alojzij Kraševec, Božo Milanović, Marko Zlatić, Tomo Herak, Marijan Tomašić, Bogumil Medvešček i Ivan Sokolić. Ta imena navodi Milica Kacin-Wohinz pozivajući se na članak „Občni zbor Političnega društva Edinost na Opčinah“ u Edinosti od 12. srpnja 1922., ali u članku se devetero Istrana ne navodi poimence. U Edinosti se oni spominju nekoliko dana nakon skupštine u Opčinama, kada je u sporu između Milanovića i Wilfana u povodu vođenja aktivnosti oko konstituiranja novoga Odbora Edinosti on formiran 17. srpnja. Na zborovanju Istrana u Kozini 10. srpnja izabran je širi odbor od 24 člana na prijedlog Bože Milanovića. Uži se odbor po izvještavanju Pučkoga prïatelja od 13. srpnja spominje, ali nije izrijekom navedeno da je i oblikovan. No, na skupštini Edinosti je dan poslije, 11. srpnja, određeno da će u Odboru biti devet Istrana i devet Tršćana, da bi se nakon razmimoilaženja Milanovića i Wilfana definirala situacija 17. srpnja. O sastavu novoga Odbora Političkoga društva Edinost, u kojem se nalaze spomenuta devetorica Istrana i ostalih devet Tršćana, izvješćuje Edinost od 18. srpnja. ${ }^{45}$ Od navedenih pojedinaca formiran je prethodno istoga 17. srpnja novi Pododbor Političkoga društva Edinost za Istru: predsjednik Mirko Vratović, potpredsjednik Božo Milanović, tajnik i blagajnik Ivan Stari, odbornici Marijan Tomašić, Tomo Herak, Alojzij Kraševec, Ivan Sokolić, Marko Zlatić i Bogumil Medvešček ${ }^{46}$ te su oni uključeni u zajednički Odbor Edinosti.

Goričani su 13. srpnja održali osnivačku skupštinu svojega Političkog društva Edinost za Goričku, ${ }^{47}$ a burna skupština u Kozini 10. srpnja Istarskoga pododbora Edinosti pokazatelj je izraženih napetosti koje u tom trenutku još nisu dovele do raskola unutar Istarskoga pododbora, ali su vodile prema njemu.

Po tumačenju Josipa Wilfana, Istra se nije mogla odvojiti od Trsta jer po izgonu Hrvata iz Pule nije više imala svojega središta i ostao joj je tako Trst, a autonomiju goričkih Slovenaca je smatrao relativnom jer će svoje lokalne probleme morati rješavati sporazumno s drugima, preko Narodnoga vijeća, s obzirom na to da su ti problemi od nacionalnoga značenja.

45 Isto, 160, 167-168; „Dnevne vesti. Novi odbor Političnega društva Edinost v Trstu“, Edinost, 18. julija 1922.; „Domaće vijesti. Novi odbor Političkog društva 'Edinosti’ u Trstu.“, Pučki prïatelj, 20. srpnja 1922.

46 „Domaće vijesti. Novi odbor Pododbora za Istru.“, Pučki prijatelj, 20. srpnja 1922.

47 Kacin-Wohinz, Narodnoobrambno gibanje primorskih Slovencev v letih 1921-1928, I, $160-162$. 
Ipak, jedinstvo Trsta i Istre - jer da je Istra imala premalo sposobnih ljudi za vođenje samostalne organizacije (kako je pisala tršćanska Edinost), zatim, da su bile glavne gospodarske ustanove, zadruge i novčani zavodi koncentrirani pri organizaciji u Trstu, pa da je zato grad Trst morao predstavljati središte Istrana $^{48}$ - zapravo nije bilo ovisno o tim činjenicama jer ubrzo po odvajanju goričkih doći će do osamostaljenja i istarskih kršćanskih socijalista, koji će pokrenuti svoju organizaciju. ${ }^{49}$

Božo Milanović piše da su „valovi stvaralačke borbe“ među Slovencima udarali neposredno u Istrane te ih sve više dijelili po načelnoj opredijeljenosti i osobnom prijateljstvu. Premda su Istrani utemeljili svoj Pododbor da bi radili samostalno, ipak su na njih djelovale idejno-političke slovenske podjele, a to je izazvalo iste podjele među njima samim ili pospješilo obnovu predratnih idejnih razlika u nazorima. Za Istrane su se otimale obje slovenske skupine. Milanović smatra da su za njih bili „dapače jezičac na vagi“, premda tada to nisu primjećivali. S Istranima su odbornici Edinosti izgledali kao političko zastupstvo čitave hrvatske i slovenske manjine jer je i u Goričkoj Edinost imala nešto svojih pristalica, „dok su Goričani ostali smo jedna pokrajinska skupina“. Da su se Istrani priključili Goričanima, bili bi oni zajedno među tršćanskim Slovencima smatrani organizacijom cijele manjine, a Edinost bi, međutim, izgledala i pred mjesnom javnosti i pred jugoslavenskim konzulatom u Trstu kao obična pokrajinska skupina, što bi imalo i praktičnih posljedica. ${ }^{50}$

Virgilij Šček, koji je svoje goričke kršćanske socijaliste želio osloboditi pokroviteljstva tršćanske Edinosti te ostvariti ravnopravnost i legalitet Goričana, bit će u sukobu s vodstvom Edinosti, odnosno njegovim predsjednikom Josipom Wilfanom. Milanović tumači da Ščekov pokušaj osnivanja kršćansko-socijalne organizacije u Gorici nije dugo trajao. Puno je više imao uspjeha s pokretanjem novina Mali list, koji je bio prihvaćen u Trstu i sjevernoj Istri. Velik uspjeh imalo je i Ljudsko tajništvo, koje je u Gorici otvorio pravnik Josip Bitežnik, Ščekov pristalica. On je, radeći u Tajništvu

48 Antun (Ante) Iveša, ondašnji tajnik Istarskoga pododbora, piše da se nacionalno-liberalna skupina istarskih Hrvata vezivala za Političko društvo Edinost iz Trsta jer je ta organizacija imala veće političke mogućnosti za djelovanje u narodu. Tršćansko je vodstvo imalo mrežu povjerenika, opremljenu tiskaru, dnevni list Edinost, Zadružni savez, novčane zavode i druga društva te dobre veze s političarima u Kraljevini SHS. Ante Iveša, „Tršćanska hrvatska štampa između dva rata“, Pazinski memorijal 1970., 2 , 1971., 151.

49 Kacin-Wohinz, Narodnoobrambno gibanje primorskih Slovencev v letih 1921-1928, I, 165-166

50 Božo Milanović, „Tršćanska hrvatska štampa između dva rata s osvrtom na Istru“, Pazinski memorijal 1970., 2, 1971., 137. 
kao pravnik, davao ljudima besplatne pravne savjete, pisao im molbe i žalbe te je tako djelujući pridobivao pristalice za kršćanske socijaliste. Premda su Milanović i krug oko Pučkoga prijatelja odgajani u duhu Mahnićeva borbenoga katolicizma, u smislu traženja strogoga distanciranja od onih koji javno ne prihvaćaju katolička načela kao normu društvenoga djelovanja, ipak je u njima bio prisutan Dobrilin duh narodne sloge. Zato su Milanović i Pučki prïatelj izbjegavali pisanje koje bi moglo unijeti razdor u političko djelovanje istarskih Hrvata i Slovenaca. Iz toga će proizlaziti njegovo početno nastojanje da se ne prikloni ni jednoj od suprotstavljenih slovenskih strana. Na Ščekov poziv da se grupa oko Pučkoga prijatelja pridruži goričkoj kršćansko-socijalnoj grupi Milanović se nije obazirao, što je dovelo do zahlađenja odnosa dvojice poznanika još sa studija u Gorici. Isto tako Milanović neće prihvatiti Wilfanovu ponudu da će Tiskovnom društvu u Pazinu priskrbiti 50 ooo lira kao odštetu za gubitak tiskare u Pazinu i da će isplatiti kod tiskare Edinosti dug Pučkoga prijatelja u visini 20 ooo lira. Uz te uvjete bi se, naime, morala skupina oko Tiskovnoga društva i Pučkoga prïjatelja posve staviti na stranu tršćanskoga društva Edinost i odreći se svake suradnje s goričkim kršćanskim socijalistima. Takav bi postupak bio protivan načelima i minulom radu pristalica Tiskovnoga društva i Pučkoga prijatelja. Milanović objašnjava da bi se Tiskovnom društvu morala pružiti pomoć bez ikakve obveze jer ono nije izgubilo tiskaru i zadužilo se tiskanjem Pučkoga prijatelja zbog stranačke nego zbog isključivo nacionalne koristi. Wilfan će nakon Milanovićeva odbijanja pozvati u Trst Mirka Vratovića da preuzme vodstvo istarske liberalne skupine te da formira novi Istarski pododbor i da ga spoji s Političkim društvom Edinost u Trstu. ${ }^{51}$

\section{Polemika između Učiteljskoga lista i Pučkoga prijatelja kao uvod u skupštinu u Kozini 10. srpnja 1922.}

U vrijeme predsjedavanja Bože Milanovića Istarskim pododborom, od srpnja 1921. do skupštine u Kozini 10. srpnja 1922., idejna su se razilaženja među Istranima u javnosti izrazila u trenutku kada su uslijedile reakcije na koledar Istranin za 1922. godinu. Izdalo ga je Tiskovno društvo u Pazinu. Na jednoj su strani bili Tiskovno društvo u Pazinu i Pučki prijatelj, nasu-

51 Milanović, Istra u 20. stoljeću, 1, 132-134, 137-138; isti, Moje uspomene, 58-59; Trogrlić, „Nacionalnopreporodni rad mons. Bože Milanovića u tršćanskom razdoblju 1922.-1945.“, $139-141$. 
prot krugova oko Učiteljskoga lista, ${ }^{52}$ inače glasila Zveze slovanskih učiteljskih društev v Trstu. U podnaslovu prvoga broja Učiteljskoga lista od 1. ožujka 1920. navedeno je da je to glasilo Zveze jugoslovanskih učiteljskih društev v Trstu.

Ivan Vouk ${ }^{53}$ pisao je u Učiteljskom listu kako lijepoj vanjštini Istranina ne odgovara sadržaj knjige. Takozvano poučno štivo obuhvaća oko 80 (od 118) stranica, na kojima se nalaze „leposlovni sestavki (če jih smemo imenovati tako)“, povijesno-politički članci, nekrolozi četiriju znamenitih Istrana: „oba Mahnića“ ${ }^{54} \check{S}_{\text {Sime Kurelića }}^{55}$ i Ante Kalca, ${ }^{56}$ nekoliko gospodarskih i drugih praktičnih i nepraktičnih tekstova i sve to bez ikakva smislenoga estetskog reda. Za koledar koji će biti zabavan i poučan treba nešto bolje, piše da se ne smije smatrati „našega kmeta“ tako naivnim i primitivnim te pretpostavljati da će mu se takvo dosadno djelo dopasti. Vouk navodi da nije pisao s lošim namjerama već sa željom da se u tom smislu krene na bolje. Ono što ide među ljude, treba biti dobro, zdravo i lijepo. Ističe da to nije samo njegov sud, „ampak graja je splošna“. ${ }^{57}$

52 Kao glasilo jugoslavenskih učiteljskih društava u Italiji izlazi u Trstu od 1920. do 1926. Pored bavljenja pedagoško-metodičkim sadržajem, zalagao se za staleška prava, za očuvanje nacionalnih prava Hrvata i Slovenaca pod Italijom, a napose za očuvanje materinskoga jezika u osnovnim školama. Mate Demarin, Hrvatsko školstvo u Istri, Zagreb 1978., 158

53 Na glavnoj skupštini Političkoga društva Edinost 4. travnja 1921. u novi Odbor od onih koji su predstavljali Tršćane postavljen je i Ivan Vouk. „Glavna skupština političkog društva 'Edinost' u Divači, u ponedeljak, 4. travnja, godine 1921.", Pučki prijatelj, 7. travnja 1921.; Kacin-Wohinz, Narodnoobrambno gibanje primorskih Slovencev v letih 1921-1928, I, 40-41. U Trstu je 2. ožujka 1921. utemeljeno kulturno društvo Prosvjeta, a za predsjednika je izabran Ivo Vouk. „Ustanovna skupština 'Prosvete' u Trstu“, Pučki prijatelj, 9. ožujka 1922. Prosvjeta u Trstu izdala je 1922. djelo Josipa Ribičiča i Ivana Vouka Šest mladinskih iger, „Književnost in umetnost“, Učiteljski list, 10. i 20. aprila 1922. O Ivanu Vouku: Kramar, Narodna prebuja istrskih Slovencev, 272, 313-314, 320; Jasna Čebron, „Vouk, Ivan“, Istarska enciklopedija, ur. Miroslav Bertoša i Robert Matijašić, Zagreb 2005., 889.

54 Krčki biskup Anton Mahnić (Mahnič). Vidi o njemu: Aleš Ušeničnik, Sociologija, Ljubljana 1910., 507-508; Drago Klemenčič, „Mahnič Anton“, Primorski slovenski biografski leksikon, 9. snopič, ur. Martin Jevnikar, Gorica 1983., 325-328; isti, „Kratek pregled Mahničevega življenja in dela“, Mahničev simpozij v Rimu, ur. Edo Škulj, Celje 1990., 7-18; Mirko Juraj Mataušić, „Publicističko djelovanje biskupa Mahnića u Hrvatskoj“, Mahničev simpozij v Rimu, 327-352; Milanović, Hrvatski narodni preporod u Istri, II, 332-335, 339-340. Kako Ivan Vouk u osvrtu na koledar navodi „oba Mahnića“, a kako mi nije bio dostupan koledar, pretpostavljam da je ovaj drugi pravnik Rihard Mahnič (1855. - 1924). O njemu: Lc [Ljubomir A. Lisac ], „Mahnič, Rihard“, Primorski slovenski biografski leksikon, 9. snopič, 329. Vouk je bio privrženik kršćanskosocijalne struje. Kacin-Wohinz, Narodnoobrambno gibanje primorskih Slovencev v letih 1921-1928, I, 96-97.

55 O njemu: Galiano Labinjan, „Dr. Šime Kurelić - glavar mjesne općine Pazin od 1898. do 1918. godine“, Hrvatska čitaonica u Pazinu, 43-59.

56 Antun Kalac, biskupski povjerenik, pazinski prošt i dekan u austrijskom razdoblju. O njemu: Vjekoslav Spinčić, Crtice iz hrvatske književne kulture Istre, Zagreb 1926., 109-110; Vjekoslav Kalac, „Antun Kalac, istarski pjesnik - rodoljub“, Istarska Danica 1973., Pazin 1972., 54-57; Mirjana Strčić, „Antun Kalac hrvatski narodni preporoditelj i pjesnik“, Hrvatska čitaonica u Pazinu, 177-186; Milanović, Hrvatski narodni preporod u Istri, II, 307.

57 „Knjige ni izdal privatnik, ki hoče napraviti pri tem umazan dobiček, ampak narodno podjetje, kateremu zadostuje, če se stroški pokrijejo. Vsaj mislim, da je temu tako. Vsled tega moramo nastojati, da so tudi take in podobne izdaje namenjene pravi ljudski zabavi in vzgoji, a prilagoditi jih je treba tudi nekemu estetskemu okusu. Tem zahtevam pa vsebina koledarja ne odgovarja.“Iv. [Ivan] Vouk, „Književna novost. 'Istranin', Koledar za prostu godinu 1922. (Sa slikama.) Trst 1922. Založilo: 'Tiskovno društvo u Pazinu'. 
O kalendaru Božo Milanović piše da je to bila knjižica koja je, „u onoj nevolji“ kad hrvatski narod u Istri nije imao ni običnih zidnih kalendara, ipak bila nešto. Onodobni cilj kršćanskih socijalista nije bio izdavanje djela visoke književne vrijednosti, to bi u tadašnjim prilikama bio luksuz; išlo se za tim da se izdaju knjige za puk, popularno i zanimljivo štivo, i po mogućnosti korisne. Nastojalo se izdavati štivo i za djecu, koja su inače polazila talijanske škole. ${ }^{58}$

Reagiranje na pisanje dopisnika Učiteljskoga lista uslijedilo je u Pučkom prijatelju od 9. veljače 1922. Tvrdi se da je koledar Istranin u kratko vrijeme doživio same pohvale, narod ga je prihvatio objeručke, svima se svidjela njegova vanjština, a napose njegov poučni sadržaj, a da iznimku u osvrtima čine samo neki „estetici“, koji uopće ne poznaju psihu istarskoga naroda. Vouk tvrdi da je „graja“ općenita, što njima nije poznato. Ne tvrde „da su koledar ispisali najveći znanstvenici“, ali neće dopustiti da se tako ponižavaju književnici i pjesnici. Preporučeno mu je da pomnije pročita članke u koledaru te da pogleda literarnu produkciju u vlastitoj kući ${ }^{59}$ pa tek onda neka piše o hrvatskim koledarima. ${ }^{60}$

Nakon čitanja teksta u Učiteljskom listu i reakcije na nj u Pučkom prijatelju, stječe se dojam da se prije svega radilo o neslaganju oko kvalitete izdanoga koledara. Međutim, naredno pisanje u glasilima bile su reakcije koje su proizlazile iz razlika u nazorima, iz stvarnih idejnih razlika. Dan nakon izlaska teksta u Pučkom prijatelju, u Učiteljskom listu izlazi nepotpisan članak - nešto poslije kroz diskusiju saznat će se njegov autor - koji je potaknuo daleko veće tenzije. U njemu se odobrava što će izdavači, nakladom „Katoliškog tiskovnog društva u Pazinu“ ${ }^{61}$ pružiti istarskim Hrvatima lijepo „, sastavljen koledar neke vrednosti“, ali i zamjera što nisu pozvali na suradnju istarsko učiteljstvo. ${ }^{62}$ No, Tiskovno društvo u Pazinu uzvratilo je da još nikada nije

Tiskala: Tiskarna 'Edinost' v Trstu“, Učiteljski list, 1. februarja 1922.

58 Uz godišnju Danicu izdali su i ove knjige: Gospodarska čitanka, Istarska pjesmarica, Rožica moja, Pravna čitanka, Veterinarska čitanka, Gnojenje i gnojiva, Nazorova Boškarina, Pregeljev roman Božji međaši, Kačićev Razgovor ugodni (u izboru), Kolačići i Ciba-Biba (za djecu), koju je popratio slikama Saša Santel, Oj mladosti, oj dragosti, Šenoin Prosjak Luka, Genoveva, Zabavnik, tri knjige Zabavnih pripovijesti itd. Opširnije o radu i djelovanju na izdavanju pučkih knjiga Društva sv. Mohora za Istru, utemeljenoga 1924.: Milanović, Hrvatski narodni preporod u Istri, II, 525-532; isti, ,Tršćanska hrvatska štampa između dva rata s osvrtom na Istru“, 143-147; isti, Istra u 20. stoljeću, 1, 228-238; Ivan Grah, „Društvo sv. Mohora za Istru (19241947) i zidni kalendar 1944.“, Istarska Danica 1994., Pazin 1993., 72-76; Trogrlić, Mons. Božo Milanović, istarski svećenik, 69-72.

59 Najvjerojatnije se misli na tršćansko kulturno društvo Prosvjeta. Vidi bilj. 53.

60 „Hic Rhodus, hic salta!“, Pučki prijatelj, 9. veljače 1922.

61 Tj. Tiskovnoga društva u Pazinu.

62 „Jest, nama je začudno i uvredjeni smo, što izlazi ‘Istranin’ za Istrane u Istri, a da za nj nije znalo istarsko 
čulo od kojega učitelja ni riječi o takvom postupanju prema njima. Nije se nikada, tvrdi se u članku, izrazilo protiv učiteljskoga staleža, nego je u svom listu Pučki prijatelj uvijek naglašavalo zasluge hrvatskoga učiteljstva u Istri u radu za narod te je uvijek zastupalo uvjerenje da moraju složno i zajednički raditi svi staleži, osobito svećenici i učitelji kao glavni radnici na kulturnom i gospodarskom podizanju naroda. ${ }^{63}$

Nakon osvrta u Učiteljskom listu o Komunističkom koledaru za 1922. godinu, ${ }^{64}$ uz „Pripombu uredništva“, u kojoj između ostaloga stoji: „Dolžnost vsakega učitelja, pa če je tudi nasprotnik mislim, o katerih razpravljajo članki Kom. kol., ${ }^{65}$ je, da knjigo resno preštudira, sicer naj se ne šteje k intelektualcem!“ ${ }^{66}$ Tiskovno je društvo reagiralo tvrdnjom da je Uredništvo Učiteljskoga lista „Zagrlilo i preporučilo komunistički koledar“. Njihov je koledar „s najvećom ironijom osudilo“, a komunistički uzdiže, pišući da svakoga tko ga ne pročita ne „smatra intelektualnim čovjekom!“ Spočitava da Učiteljski list s jedne strane napada ono što je nacionalno, a s druge strane vodi ,agitaciju za internacijonalni (nenarodni) komunizam“. ${ }^{67}$

Uslijedit će reakcija Josipa Pahora u Učiteljskom listu na nezadovoljstvo Tiskovnoga društva jer je urednik hrvatskoga dijela Učiteljskoga lista ${ }^{68}$ iznio opasku na račun koledara Istranin o omalovažavanju učitelja. Piše da bi po logici Tiskovnoga društva Zagreb bio ljepši od Pariza samo zato jer je hrvatski. Napominje da se kritičar Istranina potpisao, ${ }^{69}$ kako se potpisao i kritičar Komunističkoga koledara ${ }^{70}$. „Pripomba uredništva“ nakon kritike Komunističkoga koledara je slovenska; treba razlikovati slovenski dio Učiteljskoga lista, koji ima svoje nezavisno uredništvo, i hrvatski dio toga lista. Kad Istranin nije pohvaljen, slovensko uredništvo nije ništa krivo - kao što je i hrvatski urednik nedužan kad je preporučen Komunistički koledar. Plašenje obrazovanih ljudi komunizmom zbog toga jer je internacionalan

hrvatsko učiteljstvo, koje je sada najbrojnije naobraženi sloj našeg naroda i koji sada nosi i vrši najteže narodne poslove. Zar da vraćamo šilo za ognjilo? zub za zub? Ne bi možda škodilo, pošto mi poznamo sistem: omalovažuj učitelja gde možeš, a rabi ga kao - magarca!“” „Prezreni smo!“, Učiteljski list, 10. februarja 1922

63 „Domaće vesti. Tiskovno društvo u Pazinu. Učiteljskom listu.“, Pučki prijatelj, 9. ožujka 1922.

64 Karol Pahor, „Književnost in umetnost. Komunistični koledar“, Učiteljski list, 20. februarja 1922.

65 Tj. Komunistički koledar.

66 „Pripomba uredništva“, Učiteljski list, 20. februarja 1922.

67 „Domaće vesti. Tiskovno društvo u Pazinu. Učiteljskom listu.“, Pučki prijatelj, 9. ožujka 1922.

68 Ne navodi se ime i prezime urednika hrvatskoga dijela Učiteljskog lista.

69 Misli se na Ivana Vouka.

$70 \mathrm{Tj}$. Karol Pahor. 
također je originalno jer kršćanstvo nije ništa manje internacionalno. ${ }^{71}$ Bez obzira na oštre konstatacije Pahora, pogotovo ove posljednje, koje ukazuju na idejne i kulturne razlike u promišljanjima, ne može se iz prikazanoga pisanja u tisku zaključivati da se radilo o težnji istarskih kršćanskih socijalista da nametnu svoj utjecaj onima od kojih su se idejno razilazili. U najširem smislu shvaćeno, radilo se o različitim stavovima i pogledima oko pitanja očuvanja nacionalnih interesa, koji su mogli biti politički, gospodarski i kulturni.

Tiskovno društvo u Pazinu odgovara u Pučkom prïatelju od 6. travnja da su Pahorove tvrdnje kolosalno nelogične jer 1) nije istina da se Tiskovno društvo zauzelo za koledar samo zato jer je nacionalan i 2) jer Zagreb i Pariz, dotično pojam hrvatskoga i francuskoga jesu dvije ideje u sebi dobre, a pravi nacionalizam stoji prema komunizmu kao dobra ideja prema zloj. Time nije rečeno da komunizam nema ništa dobro u sebi, nego samo da je općenito uzevši zao. ${ }^{72}$ „Zato i komunistički koledar može biti u preraznom pogledu na visokom stepenu, ali u koliko propagira komunizam, je zao u toliko, koliko i sam komunizam. “73 Nelogičnom smatraju i Pahorovu usporedbu internacionalnoga komunizma i internacionalnoga kršćanstva jer se oba slažu samo utoliko ukoliko isključuju mržnju prema drugim narodima te zahtijevaju jednakopravnost za sve, dok posebnu i veću ljubav do vlastitoga naroda komunizam, kako ga Lenjin propovijeda, isključuje, a kršćanstvo zapovijeda. Time je zapravo komunizam nenarodan, a kršćanstvo je temelj pravoga nacionalizma. ${ }^{74} \mathrm{U}$ svojem odgovoru Tiskovno društvo navodi i to da su zahvalni Pahoru što je „otkrio, da se je u hrv. dijelu lista onako zaletio proti koledaru 'Istranin’ urednik gosp. Vinko Šepić“.

U Učiteljskom listu od 20. travnja 1922. Vinko Šepić ${ }^{75}$ kao urednik glasila navodi da neće reagirati „, viših razloga na priposlano 'Katol. tisk. društvo’ u Pazinu“, objavljeno u Pučkom prijatelju od 6. travnja: „Poznam onu dvojicu. Vidih ih i čuh na jednoj sjednici. ${ }^{76}$ Nisu mi se dopali. Mi smo za

71 Josip Pahor, „Polemika. Nekoliko odgovora 'Tiskovnemu društvu’ v Pazinu.“, Učiteljski list, 20. marca 1922.

72 Tiskovno društvo u Pazinu, „Odgovor Učiteljskemu listu“, Pučki prijatelj, 6. travnja 1922.

73 „Ispravi!“, Pučki prijatelj, 13. travnja 1922. Citirana rečenica je ispravak krivo objavljene rečenice u članku „Odgovor Učiteljskemu listu“, u Pučkom prijatelju od 6. travnja 1922.

74 Tiskovno društvo u Pazinu, „Odgovor Učiteljskemu listu“, Pučki prijatelj, 6. travnja 1922.

75 O Vinku Šepiću: Branko Pleše, „Život i rad narodnog učitelja i rodoljuba Vinka Šepića“, Pedagoški rad, 7-8, 1984., 353-362; Božo Jakovljević, „Vinko Šepić i njegov doprinos školstvu Istre“, Buzetski zbornik, 12, 1988., 63-70; isti, „Vinko Šepić“, Arhivski vjesnik, 32/1989., 33, 21-26; isti, „Učiteljska škola u Kopru i školovanje hrvatskih učitelja“, Annales, 6, 8, 1996., 213-224; isti, „Šepić, Vinko“, Istarska enciklopedija, 870871.

76 S obzirom na ovu Šepićevu izjavu, očito je da su dva predstavnika Tiskovnoga društva u Pazinu napisala 
posvemašnju slogu i zajednički rad u Istri. Držim, da imadu nakanu nahuckati učiteljstvo, te ih razdvojiti. Mi toga ne ćemo, pa makar to želio i sam Marko Kraljević.“77 Napominje da je Učiteljski list upozorio „da se ne izdavaju u Istri knjige i novine pod imenom 'Istranin'“ jer oni vole „isticati narodno naše ime.“ Nastavlja da se Pahor nije dobro izrazio kada je spomenuo da je urednik hrvatskoga dijela Učiteljskoga lista iznio na račun koledara Istranin određenu opasku: ${ }^{78}$ „On to ne može nit smije ustvrditi, a bit će to učinio, da i on podupre one od 'T. društva', ${ }^{79}$ da se svadjamo i razdvajamo. - O stvari više ne ću govoriti, jer ću i nadalje raditi u gornjem smislu, koji isključuje separatizam i eskluzivizam." ${ }^{80}$

Reagirao je i Josip Pahor na pisanje Pučkoga prijatelja od 6. travnja 1922. Uz ono što je već u diskusïi rečeno, ističe i da želi pobiti neke tvrdnje, prije svih da je komunizam neupitno zlo. ${ }^{81}$

Uredništvo Pučkoga prijatelja navodi da bi sada u polemici trebale započeti znanstvene rasprave o komunizmu i odnosu kršćanstva prema nacionalizmu, ali to onemogućuje prostor lista, kao i njegova svrha. No, „iz pouzdanih informacija našeg uredništva“ može se ,javiti, da se u istarskoj politici apsolutno ne radi o kakvom separatizmu, jer su u svim glavnim pitanjima sve naše važnije istarske političke ličnosti posve sporazumne. Jedinstvo se priznaje, a zahtijeva se samostalnost u toliko, u koliko zahti-

odgovor u Pučkom prijatelju od 6. travnja, ali se ne može uočiti jesu li bili iz učiteljskih redova. Mogli su biti ako je riječ o nekoj sjednici Jugoslavenskoga učiteljskog društva u Pazinu, kojem je predsjednik bio Vinko Šepić, a tajnik Antun Ladavac. Je li možda riječ o sjednici Istarskoga pododbora Političkoga društva Edinost?

77 V. ̌̌. [Vinko Šepić], „Listnica Uredništva“, Učiteljski list, 20. aprila 1922

78 Josip Pahor u tom članku piše: „Ker je tudi urednik hrvatskega dela 'Učiteljskega lista' napravil na račun 'Istranina' opazko 'omalovažuj učitelja, gdje možeš, a rabi ga - kao magarca', so gospodje pri T. d. hudi in se v 'Pučkem prijatelju' vsak dan bolj čudijo Učit. listu.“ „Polemika. Nekoliko odgovora 'Tiskovnemu društvu' v Pazinu.“, Učiteljski list, 20. marca 1922.

79 Tj. Tiskovnoga društva.

80 Šepić, „Listnica Uredništva“, Učiteljski list, 20. aprila 1922.

81 „Narodnost ni več druzega kakor vsota značilnih svojstev naroda, nacionalizem pa ohranitev teh značilnih svojstev in pravica osnovati svojo (narodno) državo. To bi bil po mnenju g. dialektikov pravi (tako istaknuto u tekstu; op. Ž. K.) nacionalizem - nasprotju menda - s šovinizmom kot nepravim nacionalizmom. Komunizem je pa gospodarski sistem, po katerem naj bi bilo vse imetje skupno. Kako je potem mogoče postaviti nacionalizem proti komunizmu kakor dobro idejo proti slabi? Kaj lahko! Z logiko Tiskovnega društva u Pazinu! 'Time nije rečeno, da komunizam nema ništa dobra u sebi, nego samo da je općenito uzevši zao.' Torej je slab in dober obenem. “ Tvrdnja da je komunizam općenito uzevši na svaki način zlo „,je prav tako neresna in nelogična kot je smešna izvirna sentenca Tisk. društva, da je krščanstvo temelj pravega (tako istaknuto u tekstu; op. Ž. K.) nacionalizma. Kdor je to zapisal, je najbrže tak pravi (tako istaknuto u tekstu; op. $\check{Z}$. K.) nacionalist, ki podreja nacionalizmu krščanstvo, čegar idejne univerzalnosti ne pozna. Vsa zgodovina nam priča, kako gre krščanstvo preko narodov in držav. Evo samo vprašanje: ili ni Loyolov preporod zahteval, da se vsemu odpove, tudi vezem rodu in krvi, kdor hoče vstopiti v Jezusovo družbo? In danes gre vzporedno s stremljenjem III. internacionale prizadevanje solidarističnih politikov in organizatorjev, da se zgradi tudi krščanska - internacionala!“ J. [Josip] Pahor, „Polemika. Kratka replika.", Uciteljski list, 30. aprila 1922. 
jeva to korist najtužnije pokrajine ${ }^{82}$ i potreba sistematskog proširenog rada. “83 Dakle, Pučki prijatelj s jedne strane napušta tematiku komunizam kršćanstvo - nacionalizam, odbacujući separatizam, te priznaje potrebnost jedinstva zahtijevajući samostalnost u smislu snažnijega sustavnog rada za nacionalne interese u pokrajini, no s druge strane $u$ istom broju glasila izlazi članak u kojem će žestoko biti kritiziran Vinko Šepić.

O tome da je Šepić napisao članak o omalovažavanju učitelja u Učiteljskom listu moglo se unutar Tiskovnoga društva i Uredništva Pučkoga prijatelja pretpostavljati, ali ne i odmah ustvrditi nakon njegova objavljivanja. Sigurno da je unutar učiteljskih redova bilo i drugih koji su mogli slično razmišljati i napisati takav ili sličan tekst. Naravno, s druge strane se ne može govoriti kako je unutar učiteljskih redova prevladavao takav ili sličan stav, ali je očito da su se unutar istarskih krugova različiti pogledi javno počeli iznositi. Premda u podnaslovu Učiteljskoga lista piše da je njegov urednik Vinko Šepić, tek nakon Pahorova pisanja će Pučki prijatelj otvoreno kritizirati urednika hrvatskoga dijela lista. Međutim, u Učiteljskom listu jednako tako nailazimo na tekstove koji otvoreno pozivaju na sporazumijevanje i dogovaranje. Primjerice, kada je bio tiskan Šepićev nepotpisani članak „Prezreni smo!“, u istom broju lista ${ }^{84}$ Mate Demarin piše o potrebi i važnosti sporazumijevanja unutar učiteljskih krugova, odnosno unutar učiteljske organizacije. $^{85}$

Pučki prijatelj istupit će otvoreno protiv Šepića. Tako se u jednom tekstu navodi da su u Istri do Svjetskoga rata odvjetnici, učitelji, svećenici, trgovci, seljaci i radnici imali samo jedan cilj: složno raditi za narod. Nikad se nisu prepirali o tome je li tko svećenik ili učitelj, nego hoće li on učiniti sve što je korisno za narod, „pa bio on jednog ili drugog kulturnog mišljenja“. To je, ipak, tek djelomično točno: premda je ideja nacionalne sloge bila prisutna u Istri među narodnjacima i u vremenu nakon Svjetskoga rata, idejna su razila-

82 Misli se na Istru.

83 „Dopisnica uredništva“, Pučki prïatelj, 11. svibnja 1922.

84 Uciteljski list, 10. februarja 1922.

85 „Tko iole promatra i prati naš učiteljski razvitak, taj mora konstatirati ovo: Ima nas najmanje od dve boje. U dve, najmanje u dve se struje delimo. (...) Nazori drugčiji, ideje različite, putevi raznovrsni a cilj? Cilj nam je približno više ili manje isti, odnosno slični. Svi želimo dobro narodu, svi hoćemo njemu služiti zanj skrbit i raditi, svi smo pripravni doprinesti žrtvu oltaru općenitosti. Stoga i moramo biti združeni i jedinstveno nastupati.“ Demarin govori o uvjetima u devet točaka kojih bi se trebala u svom radu pridržavati učiteljska organizacija. Na kraju članka završava: „Otkrijmo se! Otkrijmo se a ujedno poklonimo pred jakim i moćnim načelima: požrtvovnog rada, neslomive, iskrene i uzajamne jedinstvenosti, prave, jake i nerazdružive sloge i blaženo - kreposne sredine, jer: Svaka prenapetost škodi i razara, / A zlatna sredina oči nam otvara.“ M. [Mate] Demarin, „Otkrijmo se i sporazumimo“, Učiteljski list, 10. februarja 1922 . 
ženja u godinama pred rat bila izražena, nekada i veoma oštro, ali dinamika sukobljavanja nije nikad poprimila oblike koji bi doveli u pitanje jedinstvo Hrvatsko-slovenske stranke u Istri. Autor teksta u Pučkom prijatelju nastavlja kako se je stanje potpadanjem Istre pod Italiju drastično pogoršalo. Mnogi su se intelektualci iselili, a jedini koji su do zadnjega časa ostali i s narodom trpjeli bili su učitelji i svećenici, koji žive u najtješnjim i najboljim odnosima i međusobno i s narodom, tako da se može ustvrditi „da u našim narodnim redovima vlada posvemašnja jednodušnost“. Međutim, „izmedju dobrih narodnih dobročinitelja“ nailazi se i na ,jednog crvića, koji nikako ne može vidjeti, da se naš narod, koji je podvrgnut tolikim patnjama, stoji složan i jedinstven“. Taj „crvić“ je učitelj Vinko Šepić u Buzetu: „Kako čujemo, on bi na svaki način htio izazvati kulturni boj u Istri“, što oni svi osuđuju „kao naše najveće zlo“ jer bi to oslabilo nacionalne redove. Tekstopisac naglašava da je Šepić „bio s jedne strane upozoren neka pazi što piše neistinite vijesti“ te da je on pri tom izjavio: „Znam, bilo mi je rečeno da pošaljem što god za koledar 'Istranin', ali meni nije pravo, što će jednoga dana i 'klerikalci’ reći da rade za narod!!!“" ${ }^{86}$ Zbog toga pisac članka izražava ogorčenje i poručuje Šepiću neka bude siguran da će oni uložiti sve svoje snage da održe nacionalno jedinstvo i da spriječe „svaki kulturni boj u našem narodu“ ${ }^{87}$

Nakon ovakvoga je pisanja Vinko Šepić odlučio reagirati. Piše u Učiteljskom listu da je to „zlobni napadaj“ Pučkoga prïatelja na njegovu osobu te da je uputio dva ispravka tome listu. Prvoga je Uredništvo otklonilo jer da ne odgovara tiskovnim propisima, a drugi je priredio kako to traži bivši austrijski tiskovni zakon. ${ }^{88}$ Naredni broj Učiteljskoga lista odbacio je pisanje Pučkoga prïatelja. Navodi se da Odbor Jugoslavenskoga učiteljskog društva u Pazinu prosvjeduje protiv javnoga napada na predsjednika društva i urednika Učiteljskoga lista Vinka Šepića, zaključujući da se sazove časni sud od članova suprotstavljenih strana, koji će na temelju istrage odlučiti na čijoj je strani krivnja. ${ }^{89}$ Nisam uspio utvrditi je li se časni sud uspio sastati i je li se uopće formirao.

Odgovor na „zlobni napadaj“ Pučkoga prïatelja od 11. svibnja, kako ga je Šepić ocijenio, objavljen je u istom listu od 15. lipnja. U svojem se kratkom dopisu branio da nije izrekao inkriminiranu rečenicu da nije bio pozvan, kao

86 Citirana rečenica posebno je istaknuta u članku.

87 Le Veillon Heurteur, „Bože moj, malo nas ima - i još hoće da se cijepamo!“, Pučki prijatelj, 11. svibnja 1922.

88 V. ̌̌ . [Vinko Šepić], „Listnica Uredništva“, Učiteljski list, 1. junija 1922.

89 „Polemika. Le Veillon Heurteur in tov. Šepić.“, Učiteljski list, 10. junija 1922. Učitelja Antuna Ladavca spominje Pučki prijatelj u svom izvješćivanju o skupštini u Kozini 10. srpnja 1922. 
ni drugi učitelji, da surađuje u Istraninu te da nije rabio izraz „klerikalizam“. ${ }^{90}$

Nakon njegova „Ispravka“ uvrštena je u isti broj „Opaska Uredništva“. Napominje se da je u „onom članku“91 njihov dopisnik zasnivao svoje prigovore na tome da je Šepić radio protiv nacionalnoga jedinstva jer je u Učiteljskom listu počeo predbacivati Tiskovnom društvu da nije pozvalo na suradnju učiteljstvo, da se ono omalovažava te da ne bi škodilo uzvratiti „zub za zub“. ${ }^{2}$ To i slično, kao i kasnije pisanje u jednoj „listnici uredništva“ u Učiteljskom listu ${ }^{93}$ Šepić ne može zanijekati. Što se tiče nepozivanja učiteljstva na suradnju oko rada na koledaru, Uredništvo tvrdi kako je Šepić ipak bio pozvan na suradnju. Zamjera mu se i što za ime društva upotrebljava riječ „katoličko“, iako mu ona ne stoji u imenu. Uredništvo precizira u vezi koledara „da ga je napisao jedan naš opće poznati književnik“, ${ }^{94}$ a Tiskovno društvo izdalo ga je pod svojim imenom i time formalno preuzelo odgovornost pred javnosti i vlastima da „učini time uslugu našoj političkoj organizaciji ${ }^{95}$ - koja bi zato morala sama nositi grijehe, nametnute od g. Šepića“. ${ }^{66}$ Kako razumijevati ovaj posljednji dio navođenja ili konstataciju Uredništva? Očito u kontekstu nekoga opreza, bojazni od reakcije talijanskih vlasti. ${ }^{97}$ I na primjeru pokretanja koledara Istranin primjećuje se oprez Tiskovnoga društva kada je ono, između ostaloga, odgovaralo - na pisanje Učiteljskoga lista - da bi javni poziv na suradnju oko izdavanja koledara mogao potaknuti neke protivnike, „da nam i to poduzeće na vrijeme zapriječe“.$^{98}$

Premda je diskusija započela oko izdavanja koledara te o njegovoj estetskoj vrijednosti, to neće prevladavati u polemici već su u njoj u prvi plan izbili

90 „Iz Buzeta. Gospodin Šepić šalje - ispravak!“, Pučki prijatelj, 15. lipnja 1922.

91 Misli se na prethodni članak Le Veillon Heurteur, „Bože moj, malo nas ima - i još hoće da se cijepamo!“, Pučki prijatelj, 11. svibnja 1922.

92 Misli se na članak „Prezreni smo!“, Učiteljski list, 10. februarja 1922.

93 Najvjerojatnije već spomenuti članak V. Š., „Listnica Uredništva“, Učiteljski list, 20. aprila 1922.

94. Tako istaknuto u tekstu.

95 Tako istaknuto u tekstu.

96 „Opaska Uredništva“, Pučki prijatelj, 15. lipnja 1922.

97 Kao primjer moglo bi poslužiti pisanje Bože Milanovića kada se osvrtao na svoje djelovanje u vrijeme dok je bio predsjednikom Istarskoga pododbora tršćanske Edinosti i skrbio oko ondašnjega izdavanja Pučkoga prijatelja. Jednom prilikom je u Uredništvo došao odvjetnik i tadašnji poslanik Ulikse Stanger izručiti jedan svoj članak u kojem su Talijani bili oštro napadani. Takvo što se tada, usprkos progonima, moglo tiskati jer je još vrijedio talijanski zakon o slobodi tiska. U članku je bila navedena jedna rečenica, po kojoj bi talijanske vlasti mogle posumnjati da ju je napisao neki svećenik, zbog čega ju je Milanović uklonio. Nakon što je članak izišao u Pučkom prijatelju, došao je Stanger ponovno u Uredništvo te je Milanovića razdraženo pitao zašto mu je izostavio onu rečenicu. „Zato, “ odgovorio je, ,jer bi inače Talijani mislili da je ono napisao koji svećenik.“ „Pa šta ako misle!“- viknuo je Stanger. Milanović je odgovorio da „moramo štediti naše ljude jer će još doći takva vremena da nam neće biti dozvoljeno tiskati niti Glasnik Srca Isusova!" Milanović, Istra u 20. stoljeću, 1, 135.

98 „Opaska Uredništva“, Pučki prijatelj, 15. lipnja 1922. 
momenti koji su ukazivali na idejna razmimoilaženja, na razlike u nazorima. Kalendar Istranin za 1922. spominje Ernest Radetić pri opisivanju prilika u vrijeme državnih izbora 1921., kada se sva težina fašističkoga nasilja srušila na leđa hrvatskoga življa u Istri. Uz velik teror usuditi se izići na izbore i glasovati protiv talijanskih kandidata mogao je samo narod koji je politički i nacionalno sazreo, toliko svjestan, koliko je naš narod u Istri, komentira Radetić. ${ }^{99}$ To je posve drugačija slika stvarnosti koja dominira u odnosu na polemiziranje oko tiskanja koledara ili raspravljanja oko njegova sadržaja.

U polemici između Učiteljskoga lista i Pučkoga prijatelja predbacivanje jedne strane drugoj može poslužiti za uspoređivanje i povezivanje sa zbivanjima na skupštini u Kozini 10. srpnja 1922. Premda je tematika na toj skupštini bila druga (reorganizacija Političkoga društva Edinost), sudionici su uglavnom isti - učiteljski krugovi i krugovi oko Tiskovnoga društva u Pazinu - pa su i izričaji suprotstavljenih nazora morali biti slični. Povrh toga, skupština u Kozini, često burna i konfliktna, potvrđuje idejna razilaženja većega broja nazočnih pojedinaca iz učiteljskih redova, redova svećenstva ili pripadnika seljaštva te pravnika poput odvjetnika i poslanika Ulikse Stangera, koji su na njoj istupili sa suprotstavljenim stavovima. Ne može se ustvrditi da su iz redova učiteljstva svi jednako razmišljali, kao što je bilo i pripadnika iz redova svećenstva koji su zauzeli različit stav u vezi s reorganizacijom Političkoga društva Edinost.

Voditelji Političkoga društva Edinost su kršćanskim socijalistima u Goričkoj pa zatim i onima u Istri predbacivali da se njihov zahtjev za reorganizacijom Političkoga društva na teritorijalnoj osnovi, uz postojanje Narodnoga vijeća koje bi objedinjavalo rad, smatra narušavanjem jedinstva. Takvo su gledište socijalni kršćani odbacivali; upravo suprotno, kroz

99 „Dne 15. svibnja 1921. izvršili su se izbori za rimski parlamenat u čitavoj Italiji - i u ovim krajevima našim. Naš je narod imao u prošlosti mnogo težkih borba i s Niemcima i s Madžarima i istim Turcima ali nitko ne pamti, da bi se u kojem našem kraju pod okom vlasti zbile strahote slične onima, što smo ih vidjeli u svibnju lanjske godine prigodom onih užasnih izbora. U one strašne dane čitava je Istra bila jedno krvavo ratište: tu se pucalo, palilo, ubijalo, kao u srdcu Afrike ili Azije. Uzprkos svega toga naš se je narod držao divno, iako u onim užasnim prilikama niesmo dobili nego samo jednoga zastupnika, ipak smo pokazali svietu da nas ima i da ne ćemo da umremo“. Hrvatski je zastupnik bio Ulikse Stanger, odvjetnik iz Opatije, a Slovenci su bili izabrali Josipa Wilfana, Karla Podgornika, Josipa Lavrenčiča i Virgilija Ščeka. U Radetićevom tekstu nije jasno kada se poziva na koledar, citira li ga uvijek ili, s obzirom na promatranje i analiziranje stanja, navodi i svoje konstatacije ili ono što je kao sudionik zbivanja i svjedok vremena znao. Naime, oznake citiranoga teksta nisu svuda navedene. Ernest Radetić, Istra pod Italijom 1918-1943, Zagreb 1944., 86-87. Koledar mi nije bio dostupan u vrijeme pisanja ovoga rada. 
Narodno vijeće za Trst, Goričku i Istru oni su vidjeli mogućnost prevladavanja suprotnosti i afirmacije jedinstva. Kod istarskih kršćanskih socijalista tek se postavljanje zahtjeva da se Pučki prijatelj kao glasilo odvoji od Tiskovnoga društva ili oduzme Tiskovnom društvu ili da se uz Pučki prijatelj pokrene još jedno glasilo počinje promatrati i tumačiti narušavanjem jedinstva. Pripadnicima istarskih nacionalnih liberala će nezadovoljstvo uređivanjem Pučkoga prïatelja kada je glasilo i dalje ostalo u vlasništvu Tiskovnoga društva, postati povodom zahtjeva za pokretanjem novoga glasila, što će suprotnoj strani biti pokazatelj početka narušavanja jedinstva i u konačnici voditi raskolu.

Vinko Šepić kao urednik Učiteljskoga lista, koji je vodio polemiku s Tiskovnim društvom u Pazinu i Pučkim prijateljem, u tisku se povodom skupštine u Kozini ne spominje. Ali Antun Iveša, ondašnji tajnik Istarskoga pododbora, navodi da do kompromisnoga zaključka na skupštini u Kozini nije došlo. Božo Milanović je uz podršku gotovo svih svećenika i pojedinih predstavnika iz raznih sela središnje Istre ostao pri svom stavu da se obnovi Političko društvo za Hrvate i Slovence u Istri utemeljeno 1902., koje je tijekom rata prestalo djelovati. Drugi dio povjerenika iz južne Istre, Buzeštine, Ćićarije, Liburnije, gotovo svi učitelji i neki svećenici odlučili su da se ostane u Političkom društvu Edinost. Za takav zaključak bili su i narodni poslanik Ulikse Stanger, Viktor Car Emin, Mirko Vratović, Ivan Stari, Antun Iveša, Mate Crljenica, don Luka Kirac i predsjednik istarskih učitelja Vinko Šepić. Bilo je to zapravo, kao i prije rata, diferenciranje „naprednjaka“ i „kršćanskih socijalista“. 100

Na skupštini u Kozini 10. srpnja 1922. najžešći kritičar Tiskovnoga društva u Pazinu i svećenstva koje je ono okupljalo bio je poslanik Ulikse Stanger. Izjašnjavao se kao protivnik uređivačke politike Pučkoga prïatelja. ${ }^{101}$ Po pisanju Milanovića, Ulikse Stanger mu je i prije burne skupštine u Kozini izražavao nezadovoljstvo uređivanjem Pučkoga prijatelja, ${ }^{102}$ kada je između njih u razgovorima dolazilo do razmimoilaženja u pogledima. ${ }^{103}$ Kao

100 Iveša, „Tršćanska hrvatska štampa između dva rata“, 151.

101 „Istarska politička skupština u Kozini“, Pučki prijatelj, 13. srpnja 1922.

102 Vidi bilj. 97.

103 Milanović objašnjava razgovor sa Stangerom kada je došlo do nesporazuma između njih oko mogućega školovanja svećeničkoga podmlatka. Naime, izjavio je Stangeru da bi trebalo početi upućivati hrvatske dječake u sjemenište. Bilo je to važno za nacionalnu budućnost jer su svećenici bili još jedina hrvatska inteligencija koja je mogla ostati u Istri živjeti i djelovati među narodom pod zaštitom Crkve. Njihovi su se redovi, već otprije rijetki, zbog progona još prorijedili. Bili su tada „hrvatski dječaci objeručke primani u malo sjemenište u Kopru“, a da nisu poznavali talijanski jezik. Troškovi nisu bili veliki, ali Milanović 
izabrani narodni zastupnik - piše Milanović - Stanger ${ }^{104}$ je tada češće dolazio u Trst i teško je podnosio što je vlasnik Pučkoga prijatelja bilo Tiskovno društvo u Pazinu, premda se list odlučno zalagao za hrvatska nacionalna prava i izbjegavao isticati idejne razlike. Stanger je stanovao u Voloskom i bio je prijatelj Viktoru Caru Eminu, koji je tada marljivo surađivao u Pučkom prijatelju, pisao je redovito razgovore Jurine i Franine. Pritom je nekoliko puta napisao i pokoju rečenicu u prilog pravoslavlju. U ono je vrijeme to djelovalo kao promidžba protiv katolicizma. Zastupajući Tiskovno društvo u Pazinu kao vlasnika lista, Milanović je u početku to tolerirao, ne pridajući mu veću važnost. Kada su se zbog toga počeli javljati neki svećenici iz Istre da će vratiti primjerke Pučkoga prijatelja, izostavio je u rukopisu Viktora Cara Emina jednu sličnu rečenicu, a da sadržaj nije bio oštećen. Stanger mu je vrlo energično predbacio što se usudio precrtati nešto jednom književniku. Tako je započela borba protiv Pučkoga prijatelja. ${ }^{105}$

U vrijeme dok je Milanović vodio Istarski pododbor, Stanger piše za Pučki prïatelj, ${ }^{106}$ a glasilo prati i izvješćuje o njegovu parlamentarnom i širem javnom radu, također i u onim mjesecima kada traje diskusija između Pučkoga prijatelja i Učiteljskoga lista. ${ }^{107} \mathrm{U}$ glasilu nema nekih javnih naznaka

i njegovi istomišljenici nisu u tom smislu ništa mogli učiniti jer nisu imali sredstava na raspolaganju. Stanger bi kao narodni poslanik i politički prijatelj Wilfana mogao priskrbiti potrebnu svotu, ali je Milanovićev prijedlog odlučno odbacio: „Neka skrbi biskup!“, izgovorio je takvim glasom, ističe Milanović, da o tome s njim više nije mogao govoriti. Biskup - Talijan - skrbio je koliko je mogao, bez obzira na nacionalnost dječaka: „Njemu je bilo stalo samo do vjere, a nama i do narodnosti.“ Milanović, Istra u 20. stoljeću, 1, 135-136.

104 Ulikse Stanger bio je poslanikom od 1921. do 1924. O njegovu parlamentarnom radu, odnosno širem javnom djelovanju: Vjekoslav Bratulić, Dokumenti o obrani i istrebljenju hrvatskih škola u Istri pod Italijom, Zagreb 1955., 16, 18-19, 22-31, 36-41; Amir Muzur - Vesna Leiner, „Uliks Stanger: prilozi za biografiju velikog, neopravdano zanemarenog Istranina“, Problemi sjevernog Jadrana, 12, 2013., 85-93; Dorotea Modričan - Amir Muzur, „Talijanski parlamentarac Uliks Stanger i Klana: visoka politika 1920-tih između načela i lokalnih interesa“, Zbornik Društva za porjesnicu Klana, 9, Klana 2016., 223-228; Demarin, Hrvatsko školstvo u Istri, 160; Kacin-Wohinz, Primorski Slovenci pod italijansko zasedbo, 294-295, 389, 397.

105 Milanović, „Tršćanska hrvatska štampa između dva rata s osvrtom na Istru“, 135.

106 Npr., Ulikse Stanger, „Pokrajinsko zakonodavstvo i porez na vino“, Pučki prijatelj, 20. listopada 192 1.; isti, „Bobu bob ili svakome svoje“, isto, 22. lipnja 1922.

107 „Kalvarija istarskih Slovena. Izjave našeg narodnog zastupnika dra. Uliksa Stangera“, Pučki prijatelj, 13. listopada 1921.; „Kalvarija istarskih Jugoslovena. Izjave narodnog zastupnika dr. Uliksa Stangera.“, isto, 10. studenog 1921. Glasilo izvješćuje da je Stanger, između ostaloga, postavio vladi u Rimu upit da priopći što se učinilo da neki poštanski uredi u Istri prestanu upotrebljavati novine Pučki prijatelj kao papir za omote, umjesto da se novine dostave pretplatnicima: „Nar. poslanik dr. Stanger za naše narodne i gospodarske potrebe“, isto, 8. prosinca 1921.; „Nar. poslanik dr. Stanger za naše narodne i gospodarske potrebe“, isto, 15. prosinca 1921. Pučki prijatelj prikazuje i djelovanje hrvatskih i slovenskih poslanika u vezi škola, učiteljišta, gimnazija: „Rad naših poslanika. Interpelacije poradi nepravde i nasilja.“, isto, 22. prosinca 1921., kao i aktivnosti Stangera povodom nadolazećih općinskih izbora: „Dopisi. Iz Veprinštine“, isto, 12. siječnja 1922.; „Izbori u Voloskom i Opatiji. Oružnici i Fašisti.“, isto, 2. veljače 1922. Reagira na pisanje lista La Voce del Carnaro o Stangeru povodom općinskih izbora: „Iz Liburnije. (Što pišu talijanske novine.)“, isto, 16. veljače 1922. Pučki prijatelj objavljuje dopis u kojem navodi Stangerov upit ministru Mornarice o namjeri da se odredi da radnici pulskoga Arsenala moraju stanovati unutar promjera od pet kilometara, izuzimajući Vodnjan i Galižanu jer ta mjesta imaju dobar željeznički spoj radničkim vlakovima. Po izjavi ministra, pokazuje se potreba nadziranja radnika koji stanuju dalje od pet kilometara 
Stangerove protivnosti Pučkom prïatelju, osim - kako Milanović svjedoči u osobnim razgovorima. Glasilo čak navodi da je Stanger promijenio svoje mišljenje o reorganizaciji Političkoga društva Edinost. ${ }^{108}$ Međutim, polemika Pučkoga prijatelja i Učiteljskoga lista, koja se protegnula kroz nekoliko mjeseci, morala je imati utjecaja na istarske krugove, pa i potaknuti obnavljanje idejnih razmimoilaženja. S druge strane, ona će se odvijati u daleko većim poslijeratnim društvenim suprotnostima unutar talijanske države, kojoj je pripadala i istarska sredina, u odnosu na postojeće suprotnosti u predratnoj Austro-Ugarskoj. Političko-nacionalne, gospodarske i kulturne suprotnosti u talijanskom društvu morale su utjecati na istarske krugove, na istarske javne radnike, kao i na nacionalne radnike u Trstu i Goričkoj, da te suprotnosti potaknu nekadašnje njihove idejne razlike i da se one nastave radikalizirati. Idejni su se sukobi unutar istarskih krugova privremeno zbog fašističkoga pritiska morali obustaviti jer će fašisti krajem listopada 1922. doći na vlast pa će to i jednu i drugu stranu upućivati na dogovor, premda razlike stvarno nikad nisu prevladane. Treba reći da je težnja za objedinjavanjem rada uvijek postojala, ali istodobno su stalna suprotstavljanja onemogućivala da se ono i ostvari. To ne znači da pripadnici jedne i druge skupine nisu održavali razgovore i veze. Fašistička zabrana rada i djelovanja hrvatskih i slovenskih institucija krajem dvadesetih godina, kada su gotovo svi prvaci kršćansko-socijalne i nacionalno-liberalne skupine bili prisiljeni na emigraciju, u krajnosti znači i prestanak idejnih sukoba unutar istarskih krugova na terenu u pokrajini.

Na godišnjoj skupštini Tiskovnoga društva u Pazinu 4. srpnja 1922., nekoliko dana pred skupštinu u Kozini, u donesenoj su rezoluciji članovi Tiskovnoga društva osudili dotadašnje i moguće buduće pokušaje nekih pojedinaca koji izravno ili neizravno rade protiv vlasništva Tiskovnoga

od Pule, osobito za liječničke izvide koji su skupi i teški. Time se radnici okoriste, pogotovo u vrijeme sjetve i žetve. Oni se prijave bolesnima za više ili manje dana i primaju protupravno bolesničku potporu i druge pristojbe, znajući da se kontrola teško ostvaruje i da kasni. „Iz Pule. Arsenalski radnici iz okolice i vlada.“, isto, 16. ožujka 1922.; Povodom općinskih izbora: „Domaće vesti. Sastanak u Sv. Duhu.“, „Dopisi. Buzet. Izborni sastanak u Sv. Duhu kod Buzeta. Poslanik Dr. Uliks Stanger med svojim narodom.“, isto, 23. ožujka 1922.; „Dopisi. Iz Berseča. Pohod našega poslanika.“, isto, 30. ožujka 1922.; „Interpelacija naših poslanika u rimskom parlamentu protiv ukinuća našeg jezika iz sudova. U Rimu, dne 1. travnja 1922." (potpisani su Josip Wilfan, Karol Podgornik, Josip Lavrenčič i Ulikse Stanger); „Poslanik dr. Stanger za Buzeštinu“, isto, 6. travnja 1922.; „Prosvjed protiv tjeranja našeg jezika sa sudova“ (potpisani su odvjetnici Andrija Stanger, Matko Trinajstić, Karlo Lukež, Ivan Poščić, Anton Mandić i Ulikse Stanger), isto, 20. travnja 1922.; „Iz Jelšana. Naš narodni poslanik dr. Stanger medju nama.“, isto, 27. travnja 1922.

108 Reagirajući na pisanje Edinosti od 23. srpnja 1922., Pučki prijatelj između ostaloga odgovara: „Nije li dr. Stanger na jednom sastanku istarskog pododbora zaključio, da samostalnu organizaciju moraju imati i Istrani, ako ju imadu i Goričani?“, „Odgovor listu 'Edinost'. I mi velimo: Ne tako, braćo!“, Pučki prijatelj, 27. srpnja 1922 . 
društva nad Pučkim prijateljem, premda to društvo izdaje list još od 1911. i za nj je podnijelo mnogo žrtava, štoviše, zbog njega izgubilo više-manje sav imetak, ${ }^{109}$ i premda je list bio uređivan na opće zadovoljstvo svih, a tako će biti uređivan i ubuduće. ${ }^{110}$

\section{Skupština u Kozini}

Na objavljeni poziv za skupštinu s navedenim dnevnim redom nisam naišao ni u izvorima ni u literaturi, ali po izvješćivanju Pučkoga prijatelja mogu se prepoznati točke o kojima se raspravljalo: izvješće predsjednika, izvješće tajnika, reorganizacija Političkoga društva Edinost, rasprava o političkom položaju, odnosno političkom stanju u Julijskoj krajini, biranje novoga odbora te razno. ${ }^{111}$

Kršćansko-socijalno glasilo o skupštini u Kozini 10. srpnja izvješćuje da je bilo prisutno oko 80 ljudi - pripadnika svećenstva, učiteljstva i drugih, a učitelji su bili najbrojniji. Seljaštva je zbog poljodjelskih poslova bilo u razmjerno manjem broju, ali su zato neki imali punomoći svojih susjeda da ih na skupštini zastupaju.

Po izvješćivanju glasila, kada je predsjednik Božo Milanović otvorio skupštinu u 10 sati i namjeravao prvom točkom dnevnoga reda podnijeti svoj predsjednički izvještaj, istupio je učitelj Antun Ladavac iz Pazina te predložio da prvo poslanik Ulikse Stanger prikaže politički položaj u Julijskoj krajini. Predsjednik se iz praktičnih razloga, da bi se sve glavnije stvari riješile prije polaska prvoga vlaka poslije podne, namjeravao držati dnevnoga reda, ali kako su neki ustrajali na prijedlogu Ladavca, predsjednik je dao riječ poslaniku. Stanger je najprije izrazio nezadovoljstvo jer da ga se „htjelo baciti iz položaja“. Govorio je o teškom položaju Hrvata i Slovenaca i

109 Misli se na uništenje Tiskare u Pazinu 15. srpnja 1920. Ona je već bila provaljena i demolirana u noći s 31. listopada na 1. studenoga 1919. Uspjelo ju se obnoviti i nastavilo se s izdavanjem Pučkoga prijatelja. Međutim, 15. srpnja 1920. pazinski fašisti provaljuju u tiskaru i potpuno je onesposobljuju za rad. Radetić, Istra pod Italijom 1918-1943, 80, 88, 90; Milanović, Hrvatski narodni preporod u Istri, II, 495, 503-504.

110 Na skupštini je izabran novi Odbor Tiskovnoga društva: predsjednik Aćim Pilat, potpredsjednik i blagajnik Božo Milanović, tajnik Stojan Brajša, odbornici Josip Grašić, Andrija Gabrovšek, Alojzij Kraševec, Srećko Jop i Josip Križmanić. U Nadzorni su odbor izabrani Pravdoslav Filiplić, Liberat Sloković i Tomo Banko. „Glavna skupština 'Tiskovnog društva u Pazinu'“, Pučki prijatelj, 6. srpnja 1922.

111 Kao primjer dnevnoga reda skupštine mogu poslužiti točke dnevnoga reda u pozivu na izvanrednu skupštinu Političkoga društva Edinost zakazanu za 1. lipnja 1922. u Opčinama kod Trsta: 1. Naša politička organizacija, pokrajinska i središnja, 2. Izbor novoga odbora, 3. Slučajnosti. Oglas je objavljen u Edinosti od 28. svibnja 1922. Pučki prijatelj od 6. srpnja 1922. objavljuje oglas za saziv skupštine Edinosti u Opčinama za 11. srpnja, gdje će na dnevnom redu biti tema reorganizacije Političkoga društva. Tematika reorganizacije političke organizacije prevladavala je na tadašnjim skupštinama. 
maloj mogućnosti da bi se u postojećim prilikama uz tek nekoliko poslanika moglo što postići kod talijanske vlade. Na skupštini je nastao smijeh kada je spomenuo slučaj da je na upit i pritužbu rimskoj vladi „o školi i talijanskom učitelju u našem selu“ ona odgovorila da su talijanski učitelji na svome mjestu, da odgovaraju svom pozivu i da su kod naroda obljubljeni. Imao je primjedbu na list Pučki prijatelj, kojemu je vlasnik ekonomska organizacija Tiskovno društvo u Pazinu, tako da „nije organ naše političke organizacije (kao što nije ni dnevnik Edinost ${ }^{112}$ ni Goriška straža. Op. ur.)“. Stanger, nezadovoljan Uredništvom lista koji je napadao Odbor Političkoga društva „(samo jedan put na lijenost tajnika! Op. ur.)“, navodi da su se sastala dva člana Tiskovnoga društva u Pazinu i dva člana Pododbora „te smo zajednički dali direktive listu, koje su točno odredjene i kojih se urednik ima držati“. Međutim, smatra da se u zadnje vrijeme urednik lista nije držao tih direktiva. Stangerova opaska da u Tiskovnom društvu „sjede razni svećenici“ izazvala je negodovanje, jedan je stariji župnik među skupštinarima reagirao: „onda što smo mi lopovi?“. Na veliku buku i negodovanje dodao je da u Tiskovnom društvu ,jesu ljudi lukavi““.113 Uslijedilo je protestiranje iz redova skupštinara pa je predsjednik morao pozvati na red. Nakon toga je Stanger „zaprijetio“ osnivanjem novoga lista kojem bi se dalo ime Naša sloga. Govorio je protiv strančarenja nekih ljudi, „ciljajući osobito na neku osobu, kojoj da vrve ideje po glavi, te uvijek govori, da bi trebalo napraviti i ovo i ono“, dodajući da bi ti ljudi htjeli surađivati s jednom strankom u Italiji. ${ }^{114}$ Oni koji „,rade po svojoj fantaziji“ i po njoj žele voditi narod su ,politički šarlatani“: „Naš pododbor nije klerikalan, nego je antiklerikalan, dapače je liberalan." I te su riječi (posebno istaknute u tekstu članka) izazvale prosvjede i poklike negodovanja da prestane govoriti: „Jedan učitelj mu je doviknuo: 'Sramite se gospodine doktore!', dok je jedan drugi učitelj

112 U raspravama o teritorijalnoj reorganizaciji Političkoga društva Edinost Josip Wilfan odbacio je mogućnost da bi se list Edinost razdijelio u tri dijela - s obzirom na tri pokrajine - zato jer nije vlasništvo Političkoga društva već posebnoga konzorcija. Kacin-Wohinz, Narodnoobrambno gibanje primorskih Slovencev v letih 1921-1928, I, 165-166.

113 Posebno su ove riječi istaknute u tekstu.

114 Misli se na Partito popolare italiano don Luigija Sturza. Edinost objavljuje i komentira dio ispravka koji je Stanger uputio tršćanskom listu L’Era Nuova povodom svojega istupanja na skupštini u Kozini. Stanger navodi da nije u Kozini, kao ni u drugim prilikama, izjavio da je protivan sporazumu s talijanskim strankama već da je rekao da moraju očuvati svoju nacionalnu individualnost i da se zbog toga treba otkloniti svaka fuzija. Sporazum ili sudjelovanje sa strankama, također s popolarima, u njegovim je željama, smatra to korisnim i potrebnim, ali oni žele imati jamstvo zbog vlastite sigurnosti, ,da osiguramo obstojanje kao drugorodna nacionalna skupina; nikako nismo raspoloženi da bi odustali od svoje nacionalne individualnosti za ljubav kakvog političkog programa“. „Popravek posl. Stangerja 'Eri Nuovi'“, Edinost, 20. julija 1922. 
skočio preda njega i uskliknuo mu usred silne buke: 'Gospodine doktore, Vi ste danas zasijali razdor medju nama!'“115

Nakon stišavanja buke i nakon što se Stanger uputio na svoje mjesto, predsjednik je dao riječ Luki Kircu, ${ }^{116}$ koji je spomenuo kako je prethodnik „predaleko išao, te je pozvao sve prisutne na jedinstvo i slogu“.

Narodni zastupnik Virgilij Šček pozdravio je skupštinu u ime Gospodarskoga saveza u Gorici. Naveo je kako je Gorička bila posve uništena od posljedica rata. Ljudi još nisu podigli svoje kuće te neki još i tada žive u barakama. Narod je zbog ratnih operacija morao otići u tuđinu pa je zato i svaki kulturni rad bio prestao. Ipak se ustrajnim radom u gospodarskom i kulturnom pogledu mnogo učinilo u Goričkoj. Pozvao je u ime političke organizacije istarski narod, a naročito inteligenciju na složan i ustrajan rad za blagostanje cjelokupnoga pučanstva jer bez sloge se ne može napredovati. Moraju se uložiti sve sile oko toga, da se uzdrži sav narod u životu i da zato moraju računati sa svakim našim čovjekom.

Predsjednik Pododbora Milanović je zahvalio poslanicima Stangeru i Ščeku, a zatim odbacio Stangerove pritužbe da ga se namjeravalo „izbaciti iz položaja“ jer je iz praktičnih razloga planirao da dođe govor o političkom položaju u Julijskoj krajini poslije treće točke dnevnoga reda. Izrazio je nezadovoljstvo što je Stanger uvrijedio članove Tiskovnoga društva, u kojem je organiziran velik dio istarskoga svećenstva, kojem se ne može predbacivati „da nije bilo dosta narodno“. Tiskovno društvo u Pazinu nije ekonomska organizacija, već kulturno društvo za širenje prosvjete u Istri „pomoću štampe“. Naglasio je „kako je on sam radio za osnutak istarskog pododbora. Nabrojio je sve poteškoće, s kojima se je istarski pododbor morao da bori. Nato je ocrtao program, pododboru predložen i od njega prihvaćen za sistematičku organizaciju političku, gospodarsku i kulturnu. Zatim je ocrtao rad pododbora kroz cijelu godinu“" ${ }^{117}$

Premda kršćansko-socijalno glasilo ne navodi konkretne podatke o programu, očito je kako je u njegovu stvaranju i oblikovanju Božo Milanović

115 „Istarska politička skupština u Kozini“, Pučki prïatelj, 13. srpnja 1922.

116 O Luki Kircu: Zadružni ugovor ili Pravila za Medulinsko družtvo za štednju $i$ zajmove, registrirana zadruga na neograničeno jamčenje, Ostavština Matka Laginje u Rukopisnoj zbirci Nacionalne i sveučilišne knjižnice u Zagrebu, Spisi koji se tiču gospodarskih i privrednih pitanja Istre (1889-1911), R-6255/XIII; Matko Rojnić, „O don Luki Kircu i njegovu radu“, u: Luka Kirac, Crtice iz istarske povijesti, Zagreb 1946., 11-20; „Don Luka Kirac (1860-1931)“, Istarska Danica 1982., Pazin 1981., 146-149; Miroslav Bertoša, „Luka Kirac

- kao povjesničar“, Prilozi o zavičaju, 3, 1983., 87-97; isti, „Kirac, Luka“, Istarska enciklopedija, 388-389; Andrej Bader, „Medulinsko društvo za štednju i zajmove“, Istarska Danica 2016., Pazin 2015., $108-111$.

117 „Istarska politička skupština u Kozini“, Pučki prijatelj, 13. srpnja 1922. 
bio aktivan čimbenik. Program rada morao je polaziti od onih smjernica o kojima je Milanović prethodno pisao u Pučkom prijatelju kada je prikazivao značenje i ulogu organizacije u postizanju političkih, gospodarskih i kulturnih ciljeva u očuvanju i ostvarenju nacionalnih interesa.

Tajnik Antun Iveša izvijestio je o tehničkoj strani rada Pododbora. Istaknuo je neprestano nazadovanje u školskom pitanju, spomenuo koledar Istranin, spomenuo uništavanje primjeraka Pučkoga prïjatelja na poštama, govorio o pokrajinskom odboru, popisu pučanstva te općinskim izborima. Zahvalio je na pomoći koju su mu savjetima dali voditelji Političkoga društva Edinost Josip Wilfan i Fortunat Mikuletič. ${ }^{118}$

Nakon Iveše je ,jedan učitelj iznio rezoluciju, kojom se najpohvalnije izrazuje priznanje Wilfanu, te se umoljava neka i nadalje ostane vodja naše političke organizacije“. Nakon pročitane rezolucije nastalo je „veliko odobravanje“.119

O društvenoj organizaciji govorio je učitelj Ivan Vouk. Razlagao je potrebu decentralizacije rada i potrebu nacionalnoga jedinstva. Predlagao je posebna društva za sve tri pokrajine, a u svrhu očuvanja jedinstva i obavljanja zajedničkih poslova te zagovarao osnutak Narodnoga vijeća. Posebno je osuđivao one koji bi htjeli prikazati pristalice te ideje protivnicima nacionalnoga jedinstva. Oni koji su bili za očuvanje Političkoga društva Edinost $\mathrm{u}$,dosadanjoj formi“ neprestano su ga ometali u govoru. ${ }^{120}$

Vouk je svojim osvrtom na koledar Istranin u Učiteljskom listu dao poticaj polemici s Tiskovnim društvom i Pučkim prijateljem, ocjenjujući kvalitetu koledara te njegov sadržaj. Kritički Voukov osvrt na koledar ne može se promatrati kroz idejne razlike s obzirom na kršćanske socijaliste jer je bio njihov privrženik. Sada se u Kozini otvoreno zauzeo za stranu koja je podržavala posebna društva za sve tri pokrajine čiji zajednički rad treba objediniti Narodno vijeće, a čega su zagovornici bili i istarski kršćanski socijalisti. Dnevnik Edinost će u polemici posebno apostrofirati njegov stav uspoređujući ga sa suprotnim stavom Luke Kirca.

Poslanik Šček tvrdio je na skupštini da tajništvo Središnjega odbora Edinosti - prije negoli je Istarski pododbor postojao - često nije u najtežim momentima ispunilo svoje zadaće. Istaknuo je da Goričani imaju preko 60 jakih razloga za odvajanje od Edinosti. „Pri tom se je razvio incidenat izme- 
dju njega i dra. Stangera." ${ }^{121}$

U članku su kao protivnici razdiobe Političkoga društva Edinost navedeni Matko Crljenica, Ulikse Stanger, Antun Iveša, Antun Ladavac, Bogomil Medvešček i Luka Kirac. ${ }^{122}$ Župnik Šime Frulić ${ }^{123}$ pročitao je izjavu župnika Josipa Grašića, ${ }^{124}$ koji je bio za osnutak posebnoga društva za Istru i zajedničko Narodno vijeće.

Uslijedit će još jedan buran dio skupštine. Uzeo je riječ Petar Sironićc ${ }^{125}$ iz Trviža. On je bio mišljenja da se u tako važnom pitanju reorganizacije Političkoga društva mora u prvom redu saslušati i uvažiti jedinstvena želja seljačkoga staleža, koji je najbrojniji u Istri. Stoga mu je žao što je Političko društvo sazvalo skupštinu baš u vrijeme kada su seljaci najviše zapo-

$121 \mathrm{Na}$ istome mjestu.

$122 \mathrm{Na}$ istome mjestu.

123 O tom župniku u Grdoselu, koji je naveden na Popisu članova prijavljenih Političkom društvu za Hrvate i Slovence u Istri utemeljenoga u Pazinu 1902.: Klen, Neki dokumenti o svećenstvu u Istri, 36, 89; Stojan Brajša - Božo Milanović, „Istarska Danica pred fašističkim sudom“, Istarska Danica 1975., Pazin 1974., 75-77; Božo Milanović, „Župnik Šime Frulić“, Istarska Danica 1978., Pazin 1977., 62; isti, Hrvatski narodni preporod u Istri, II, 306; Leopold Jurca, Moja leta v Istri pod fašizmom. Spomini, Ljubljana 1978., 26-27, 47; Ivan Grah, Istarska Crkva u ratnom vihoru (1943-1945), Pazin 1992., 89-92, 175-176; Željko Klaić, „Nacionalni pokret istarskih Hrvata i Slovenaca na prijelomu XIX. u XX. stoljeće i utemeljenje Političkoga društva za Hrvate i Slovence u Istri 1902.“ (dalje: „Nacionalni pokret istarskih Hrvata i Slovenaca“), Histria, 4, 2014., 53-54.

124 Josip Grašić, župnik u Bermu, naveden je na Popisu članova prijavljenih Političkom društvu za Hrvate i Slovence u Istri. Klaić, „Nacionalni pokret istarskih Hrvata i Slovenaca“, 53-54. O Grašiću: B. M. (nedvojbeno Božo Milanović), „Župnik Josip Grašić“, Istarska Danica 1951., Pazin 1950., 23-27; Milanović, Hrvatski narodni preporod u Istri, II, 304-306; Jurca, Moja leta v Istri pod fašizmom, 29, 31, 42-43; Željko Klaić, „Prilog proučavanju hrvatskih kreditnih zadruga i ostalih zadružnih organizacija u nekadašnjem pazinskom kapetanatu (kraj XIX. i početak XX. st.)“ (dalje: „Prilog proučavanju hrvatskih kreditnih zadruga"), Hrvatska čitaonica u Pazinu, 223, 225, 228, 241, 245, 247-248, 250-251; Vladimir Lončarević, „Kulturno-gospodarski preporodni rad Josipa Grašića“, Glas Koncila, 2. lipnja 2019., 37.

125 Petar Sironić bio je jedan je od istaknutih narodnjaka središnje Istre. Bio je dobar govornik, aktivan već u austrijskom vremenu. Spominje se tako povodom jednoga značajnog događaja na početku XX. stoljeća. Bilo je to pitanje uporabe liturgijskoga jezika, kada je tršćanski biskup Nagl u svojoj poslanici 18. listopada 1909. naveo da je Kongregacija obreda u Rimu 22. srpnja 1909. službeno objavila dekret Acres de liturgico od 18. prosinca 1906. te da je u Tršćansko-koparskoj biskupiji, osim kastavskoga dekanata, liturgijski jezik latinski. Tada je došlo do reakcija na Istarskom krasu i u središnjoj Istri, do napuštanja crkava tijekom misnoga obreda, a Političko društvo za Hrvate i Slovence u Istri odlučilo je tim povodom sazvati javnu skupštinu. Na skupštini održanoj 19. prosinca u Pazinu okupilo se više od 1000 ljudi, a glavna točka dnevnoga reda bila je službena objava biskupova dekreta. Na skupštini su govorili o pitanju prava na „slavensko bogoslužje“ Matko Laginja, Dinko Trinajstić, Fran Flego i Petar Sironić. Svi su podupirali to pravo, osim staropazinskoga župnika Stjepana Kropeka, rodom iz Varaždina. On je podržavao biskupa Nagla i s četvoricom nazočnih istomišljenika bio protiv izglasane rezolucije u prilog „slavenskoga bogoslužja“. „Na obranu našeg jezika. Velika skupština u Pazinu.“, Naša sloga, 23. prosinca 1909.; Spinčić, Slavensko bogoslužje u Istri, 168-259. Sironić je istupio između inih na sastanku pouzdanika Političkoga društva za Hrvate i Slovence u Istri mjesnih općina Pazin, Žminj, Boljun i Tinjan 19. lipnja 1913. u pazinskom Narodnom domu. Preporučio je svima da slijede stare narodne vođe pod kojima se postiglo lijepih uspjeha i optuživao „one, koji bi htjeli sijati smutnju u našim redovima“. „Sastanak Političkoga Društva u Pazinu“, Naša sloga, 3. srpnja 1913. U talijanskoj državi Sironić je stradavao od fašističkoga nasilja. Prilikom prvih državnih izbora 15. svibnja 1921. Sironić se iz svojega mjesta uputio u Pazin, ali su ga fašisti uhvatili, pretukli i teško ozlijeđena odveli u Pulu. Radetić, Istra pod Italijom 1918-1943, 86. O Petru Sironiću: „Vijesti. Petar Sironić.“, Istarska Danica 1951., Pazin 1950., 95; VIS, „Petar Sironić (Prigodom 100-godišnjice rođenja i 25-godišnjice smrti)“, Istarska Danica 1974., Pazin 1973., 92-98; Jurca, Moja leta v Istri pod fašizmom, 30, 42, 85-86, 88; Josip Šiklić, „Sironić, Petar“, Istarska enciklopedija, 726. 
sleni poljskim radovima. On je morao zapustiti žetvu i košnju da bi došao u Kozinu, a nije jedini među nazočnim seljacima. Dodaje da ga je više seljaka opunomoćilo izjaviti da su gledišta da se za Istru treba ustanoviti posebno političko društvo s Narodnim vijećem za Trst, Istru i Goričku. Uto je uslijedilo dobacivanje Matka Crljenice: „Što vas je kakav pop nagovorio, da tako govorite?“, što je izazvalo prosvjede seljaka. Sironić je uzvratio da on ne treba „nikakvih naputaka ni od popa, ni od biskupa, ni od učitelja, ni od advokata, jer znam misliti i svojom glavom! Ne bojte se, nijesmo mi seljaci tako bedasti! ${ }^{126}$ Kada dodju novi izbori, znat ćemo, koga nam je birati za našega zastupnika“. ${ }^{127}$ Nastao je kod dijela inteligencije ${ }^{128}$ velik žamor, dok je drugi dio glasno prosvjedovao što se govornika ometalo. Predsjednik je glasno pozivao na red, seljaci su bili uzrujani, a Sironić zbog ogorčenja nije više želio govoriti.

Kada se galama stišala, započeo je govoriti Engelbert Besednjak, zastupnik Goriške straže. Zauzeo se za slobodu i onih riječi, koje su htjeli izgovoriti istarski seljaci. Za cijelo vrijeme njegova govora čula se buka koju su izazivali oni koji su prije vikali protiv Sironića. Zbog toga su seljaci glasno i ogorčeno prosvjedovali, ali to nije ništa pomoglo, kao ni predsjednikovo stalno pozivanje na red. Neki su od seljaka isticali da ne govore samo u svoje ime već i u ime seljaka koji su po njima poslali punomoći jer su u to doba spriječeni doći zbog poljodjelskih radova. Kako je velik dio prisutne inteligencije bio protiv toga da bi te punomoći mogle vrijediti kod glasovanja, mnogi od tih seljaka, kao i dio inteligencije, ogorčeni su u znak prosvjeda izišli iz dvorane te se uputili na željezničku postaju i otišli kući. ${ }^{129}$

Zatim je predsjednik Slovenskoga učiteljskog društva za Istru Bogomil Medvešček pročitao rezoluciju u ime istarskih slovenskih učitelja u prilog zajednice s Trstom.

Usred velike buke Luka Kirac iznio je prijedlog za jedinstvenu organizaciju s Trstom. ${ }^{130}$ Fran Flego $^{131}$ izjavio je da nazočni nisu dobro informi-

126 Tekst je posebno istaknut u članku.

127 „Istarska politička skupština u Kozini“, Pučki prïatelj, 13. srpnja 1922.

$128 \mathrm{Kad}$ se u članku upotrebljava pojam inteligencije, misli se na pripadnike učiteljskih redova.

129 „Istarska politička skupština u Kozini“, Pučki prijatelj, 13. srpnja 1922.

$130 \mathrm{Na}$ istom mjestu.

131 Prvak istarskih narodnjaka iz Buzeta. Bio je izabran za odbornika Političkoga društva za Hrvate i Slovence u Istri kada je ono utemeljeno 1902. O njemu: Fran Barbalić, Narodna borba u Istri od 1870. do 1915. godine, Zagreb 1952., 49, 51, 55, 87, 95, 122-123; Božo Jakovljević, „Načelnici buzetske općine“, Buzetski zbornik, 12, 1988., 241-246; isti, „Općina Buzet u zapisnicima sjednica općinskog zastupstva od 1894 . do 1911. godine“, Buzetski zbornik, 20, 1995., 33-35; Kacin-Wohinz, Narodnoobrambno gibanje primorskih Slovencev v letih 1921-1928, I, 69, 167; Klaić, „Nacionalni pokret istarskih Hrvata i Slovenaca“, 53-54. 
rani o tom pitanju te da u takvoj nemirnoj situaciji ne mogu zrelo razmisliti što je najbolje: „Zato predlaže, da se izaberu od svakog dijela pokrajine po par pametnih ljudi, koji bi to pitanje dobro promozgali i tekar onda odlučili o toj tako važnoj stvari.“ „Treći prijedlog glasio je: neka se za Istru osnuje posebno društvo u sporazumu sa Goričkom.“132

Usred sve veće buke javljali su se i novi prijedlozi, ${ }^{133}$ ali prije nego ih je predsjednik uspio saslušati, „usurpirao si je društveni tajnik Antun Iveša predsjedničku vlast i povikao: tko je za jedinstvo, nek predje u ovu sobu. U tom metežu slijedili su ga drugi sa poklicima: tko je za prijedlog don Kirca, ovamo! Predsjednik je bio ogorčen nad takvim postupanjem nezakonitim i bezobraznim uzurpiranjem predsjedničke vlasti. Mnogi su počeli tako prelaziti iz jedne sobe u drugu.“ Nakon premještanja skupštinara predsjednik je konstatirao da je prijedlog Luke Kirca za jedinstvenom organizacijom s Trstom prihvaćen većinom glasova. Izvjestitelj sa skupštine komentira: „Šteta, što su već prije toga otišli oni, koji su zajedno s punomoćima sačinjavali ogromni, možda i veći dio glasova.“ Nakon toga je prihvaćen prijedlog da se izabere širi odbor od 24 člana, što je i učinjeno. ${ }^{134}$

Kod posljednje točke dnevnoga reda razvila se diskusija o Pučkom prijatelju. Naime, Stanger je odlučno zagovarao da Političko društvo osnuje novi list kojem bi se dalo staro ime Naša sloga. Milanović je upozorio na posljedice toga koraka jer bi dva tjednika u Istri značila postojanje dvije stranke, a tomu se ne može pridružiti onaj kojem je iskreno stalo do nacionalnoga jedinstva. Spomenuo je da su članovi Tiskovnoga društva u Pazinu „već mnogo žrtvovali iz svog džepa“, a budu li prisiljeni, opet će krenuti u „sakupljanje centezima za centezimom“, samo da list ne propadne. Upozorio je da je do tada narod bio zadovoljan listom, a da je Tiskovno društvo uvijek pripravno sporazumno rješavati pitanja. Nakon toga su se skupštinari mirno razišli. ${ }^{135}$

Premda je Uredništvo navelo da je željelo donijeti „što točniji i opširniji izvještaj“, sve značajno navesti, ipak naknadni osvrti na skupštinu poka-

132 „Istarska politička skupština u Kozini“, Pučki prijatelj, 13. srpnja 1922

133 U novinskom članku nema podrobnijih podataka o tim prijedlozima.

134 „Istarska politička skupština u Kozini“, Pučki prijatelj, 13. srpnja 1922.

135 „Opaska uredništva. Donesli smo evo izvještaj te naše žalosne skupštine, koja je slika naših žalosnih prilika. Nastojali smo donesti što točniji i opširniji izvještaj da se razprše razne krive i nestalne vijesti koje će se po Istri širiti. Što ćemo tajiti, kad se žalibože i onako dozna sve? Osim toga stojimo na stanovištu, da je bolje medju našim pučanstvom ne sakrivati svih naših zlih strana, jer sakrivanje ne može uvijek trajati, a mnogo šteti političkoj zrelosti našega naroda.“ „Istarska politička skupština u Kozini“, Pučki prijatelj, 13. srpnja 1922. 
zuju da svi momenti nisu bili istaknuti u izvješću. Isti broj Pučkoga prijatelja donosi reakciju skupine seljaka nakon povratka iz Kozine, a koji su imali punomoći onih koji nisu mogli nazočiti skupštini. Nezadovoljnici navode da je vrijeme njezina saziva bilo najneprikladnije za poljodjelce zaposlene košnjom i žetvom. Zato su poslali kao članovi Političkoga društva Edinost pismene izjave i punomoći, a gospoda su sve s prezirom odbacili. Prosvjeduju protiv takvoga postupka: „Zar ne volite znati mnijenje članova? Osudjujemo ponašanje tajnika 'Pododbora' napram predsjedniku. Sažaljujemo poklike: pozvat ćemo fašiste." Za govor poslanika Stangera smatraju da nije djelovao pomirbeno. Sada se osjećaju slobodnim i neobvezatnim prema svakom, a jedina će im mjerodavna biti Seljačka sloga. ${ }^{136}$ Pod tim nazivom djelovalo je društvo u Trvižu utemeljeno pred Svjetski rat, ${ }^{137}$ a na osnovi njegova navođenja može se zaključivati kako je značajan broj nezadovoljnih pripadnika seljaštva dolazio s tog dijela Pazinštine. Konačno, iz Trviža je dolazio i Petar Sironić. Nezadovoljni seljaci očekuju od Uredništva Pučkoga prïatelja da će im biti što više na usluzi, „da možemo priopćivati svoje jade. Lako je gospodi doći na sastanke, a najlakše onima, koji imadu plaćane putne troškove. Mi u takvim vremenima ne možemo tako lako putovati. Samo naprijed tako, gospodo!"138

Održana skupština u Kozini tema je jednoga osvrta u Pučkom prïatelju o tome na koji bi način institucija skupštine trebala djelovati: „Pozivi na skupštine za polaganje društvenih računa, za izbor novih odbora moraju imati uvijek svoj dnevni red, koji se mora provesti. To je skrb dotičnog društvenog predsjednika. Čim svrši dnevni red, ima prigodu svaki skupštinar, da stavlja predloge i upite. Ako hoće sazvati koji zastupnik svoje birače, da izvijesti o parlamentarnom radu, tada će biti njegov govor temelj nadaljnih rasprava i upita.“ Skupštine treba sazivati u vrijeme „prikladnije narodu, ne kako je pogodnije sazivačima“. Na skupštini Pododbora Političkoga društva Edinost za Istru 10. srpnja u Kozini disciplinu i red kršili su oni koji bili morali „prednjačiti svima dobrim primjerom“, a na njoj „pravog glasovanja u opće nije bilo. Tvrdnja o pravoj većini glasova ne može se u opće dokazati.“139

Kako se polemika o održanoj skupštini kroz tisak razvijala i zaoštra-

\footnotetext{
136 „Dopisi. Iz Pazinštine.“, Pučki prijatelj, 13. srpnja 1922.

137 Željko Mrak, „Aćim Josip Pilat i Hrvatsko katoličko mladenačko društvo“Seljačka sloga““, Istarska Danica 2009., Pazin 2008., 130-131.

138 Na kraju Dopisa navedeno je: „Slijede potpisi više seljaka-članova Polit. dr. 'Edinosti”“. „Dopisi. Iz Pazinštine.“, Pučki prijatelj, 13. srpnja 1922.

139 Jedan od starijih, „Naši sastanci i skupštine“, Pučki prijatelj, 20. srpnja 1922.
} 
vala, tako će i Pučki prïatelj iznositi nove podatke o reagiranjima pojedinaca na njoj, a o kojima u broju od 13. srpnja 1922. nije pisao. Diskusija će se dodatno zaoštriti u povodu konstituiranja novoga Istarskog pododbora, a pisanje Pučkog prijatelja od 27. srpnja, kao odgovor na pisanje Edinosti od 23. srpnja, vrhunac je suprotstavljanja i polemiziranja, gdje je iznesen niz stavova i reagiranja, ali i pojedinosti o aktivnostima koje se mogu ocijeniti kao „zakulisni postupci“.

O skupštini u Kozini tršćanska Edinost izvijestila je sadržajno drugačije (iz razumljivih razloga ne prenosim ono što se poklapa s izvješćivanjem Pučkoga prijatelja). Navodi se da je skupštini prisustvovalo $120^{140}$ članova Edinosti iz svih dijelova Istre, različite starosti i raznih staleža. Namjera im je bila da se sastanu i posavjetuju. Ulikse Stanger izvijestio je o političkom stanju. Ustvrdio je da su općinski izbori dokazali kako je teško voditi političku borbu protiv sredstava kojima se služe njihovi protivnici. Luka Kirac naglasio je da je jedino u jedinstvu i slozi njihova moć te da se iz ljubavi prema svom narodu i rodnoj grudi ne smiju dijeliti. Virgilij Šček opisao je žalostan položaj na prostoru Goričke zbog posljedica rata i naglasio potrebu da se u Gorici ustanovi samostalna politička organizacija. I on je pozivao na slogu. Predsjednik Milanović podnio je izvješće u kojem je naglasio kako su im izgnali gotovo svu hrvatsko-slovensku inteligenciju. Svoje političko društvo $^{141}$ nisu mogli obnoviti i zato su se priključili Političkom društvu Edinost iz Trsta te izabrali Istarski pododbor. Jako ga zabrinjava pomanjkanje svećeničkoga naraštaja, što bi moglo biti sudbonosno. Pododbor se bavio kulturnim i gospodarskim pitanjima. Fran Flego govorio je o progonima svećenika i drugih ljudi. „V tako težkih časih se moramo držati močnejših, a to so naši ljudje v Trstu. Med nami mora biti popolna sloga." Zatim je tajnik Antun Iveša pročitao svoje opsežno izvješće i zaključio toplim riječima o velikim sposobnostima Josipa Wilfana u narodnom vodstvu. U istom smislu govorio je „neki mladić iz Istre“, naglasivši da „Takega človeka, kakršen je dr. Wilfan, absolutno ne smemo izgubiti iz naših decimiranih vrst.“

U raspravi o društvenoj organizaciji diskusija je bila oštra. Predsjednik Milanović smatrao je da si Istra treba ustanoviti svoje samostalno političko društvo, a sva tri pokrajinska društva spajalo bi Narodno vijeće. Stanger se tome protivio. U smislu Milanovićeva prijedloga govorili su Šček, Besed-

140 Taj se podatak o broju prisutnih znatno razlikuje od podatka koji u svojem izvješćivanju navodi Pučki prijatelj. Možda upućuje na nezadovoljnike koji su napustili skupštinu?

141 Misli se na Političko društvo za Hrvate i Slovence u Istri ustanovljeno u Pazinu 1902. 
njak i Vouk. U raspravu se uključio Luka Kirac, koji je smirivao duhove te predložio da Istra ostane u Političkom društvu Edinost sa svojim Pododborom kao dotad. Šime Frulić preporučao je osnivanje samostalnoga društva, a Bogomil Medvešček izjavio je da vidi u zajedničkoj organizaciji Goričke, Trsta i Istre mogućnost uspješnoga rješavanja najvažnijih pitanja.

O prijedlozima koji su se kroz raspravu oblikovali (prijedlogu Luke Kirca da Istra ostane u Političkom društvu Edinost sa svojim Pododborom, prijedlogu Frana Flega da se iz svake pokrajine izaberu po dva pojedinca, koji neka se dogovore da se stvar riješi u ljubavi i slozi, i prijedlogu Marka Zlatića da se za Istru ustanovi posebno političko društvo i Narodno vijeće) nije se glasovalo, „pač pa so vsi, ki so bili za predlog don Kirca odšli v drugo sobo, dočim je kakih 6 oseb zapustilo dvorano. Tako je bil predlog don Kirca sprejet z veliko večino." ${ }^{142}$

Na skupštini Edinosti dan poslije, 11. srpnja, tajnik Istarskoga pododbora Antun Iveša izjavio je da su istarski članovi Političkoga društva Edinost „soglasno sklenili zaupnico dru Wilfanu s prošnjo, da ostane še nadalje narodu na čelu, kakor tudi da so z veliko večino sklenili, da ostane Istra še nadalje v sedanjem političnem društvu. “143

Kao i Pučki prijatelj, i Goriška straža je naglašavala izjavu Ulikse Stangera da je istarska organizacija antiklerikalna, da je strogo liberalna. Piše da je većina povodom toga šutjela, „trezveniji elementi su se zgrozili“, a odobravao je glasno njegovu izjavu samo „znani velemagnat“ Šiškovič. ${ }^{144}$ Goriška straža izražava nezadovoljstvo, pa i ogorčenje Stangerom, kada je govorio o svećenstvu. ${ }^{145}$ Ispravlja pisanje Edinosti da su u Kozini u prilog

142 „Glavni sestanek istrskih članov Pol. društva 'Edinost' v Kozini“, Edinost, 15. julija 1922.

143 „Občni zbor Političnega društva 'Edinost’ na Opčinah“, Edinost, 12. julija 1922.

144 Milanović spominje da je neki Slovenac Sišković (Šiškovič), u čijoj su se gostionici sastali, na održanom prijepodnevnom dijelu skupštine neprestano vikao i prosvjedovao iako nije imao ni najmanjeg povoda. Milanović, Istra u 20. stoljeću, 1, 138-139. Zagrebački Pokret koji prenosi informacije „prijatelja iz Istre“ o skupštini u Kozini, u kojima se optužuje Virgilij Šček da vodi akciju cjepkanja i slabljenja nacionalnih snaga, a podupiru namjere Josipa Wilfana i Ulikse Stangera za očuvanje Političkoga društva Edinost da i nadalje ostane sa svoja tri pododbora kao političko društvo za čitavu Julijsku krajinu, upravo apostrofira Šiškoviča: „Debata biva sve burnija pa i nakon pomirljivog govora starog nacionalnog borca Don Luke Kirca koji predlaže, da se predlog Dra Štangera (o osnutku 'Naše Sloge') stavi na glasanje: kad je izgledalo da se uopće ne će doći do nikakvog zaključka ustaje g. Šišković na stolicu, buduć predsjednik ne će da stavi predlog don Kirca na glasanje i viče: 'Tko je za predlog don Kirca neka predje u drugu sobu. Prešli su skoro svi, tako da Ščekova osnova, da završi skupštinu nije uspjela'.“ „Jezuitske intrige u Istri. Cijepanje narodnih, jugoslovenskih snaga.“, Pokret, 29. jula 1922.; „Ispravi! U članku 'Jezuitske intrige u Istri'.“, Pokret, 1. augusta 1922.

145 „Ako je kje duhovščina narodna, potem je to gotovo v Istri. Poleg Irske ni dežele, kjer bi duhovniki toliko pretrpeli kot v Istri in to prav vsled ljubezni do revnega naroda. Le berite lanski in letošnji Pučki prijatelj. Pretepajo jih vlačijo po zaporih, hiše jim požigajo, kosti jim štejejo; kakor v prvih krščanskih časih. In tem gredo očitati, da niso narodni.“ „Težka kriza v Istri“, Goriška straža, 18. julija 1922. 
samostalnoga društva u Istri govorili Ivan Vouk, Virgilij Šček i Engelbert Besednjak, tumačeći da o samostalnosti Istre nije govorio Besednjak već Istranin Šime Frulić, koji je pročitao izjavu „najodličnije narodne osobe u Istri“, ${ }^{146}$ koja se izjasnila u prilog samostalnosti. Napominje da je šteta što u izvješćivanju Edinosti nije spomenut „govor kmetskega narodnega voditelja Petra Sironića, ki je tudi govoril za samostojnost in ni govoril, kakor drugi v svojemu imenu, ampak v imenu svojih pristašev, ki so mu dali veliko število pooblastil“. ${ }^{147}$

\section{Konstituiranje novoga Pododbora}

I oko konstituiranja novoga vodstva Istarskoga pododbora polarizirali su se stavovi o tome tko će sazvati novoizabrane odbornike i kojega će se datuma to tijelo konstituirati.

Kako se novi odbor trebao konstituirati, stari predsjednik Božo Milanović pozvao je u Edinosti od 14. srpnja novoizabrane odbornike, tj. članove novoizabranoga šireg odbora da se sastanu u Trstu 25. srpnja. ${ }^{148}$ Dan poslije isti list donosi poziv s obaviješću, koji je potpisao Josip Wilfan, da će se sastanak održati 17. srpnja. ${ }^{149}$ Dva dana nakon toga, 18. srpnja, Goriška straža pogrešno piše da je Wilfan sazvao sastanak za 27. srpnja („naj se novoizvoljeni odborniki ne sestanejo 25. t. m. ampak 27.“), napominjući da je to učinio bez Milanovićeva znanja, kao i da uredništvo Edinosti nije htjelo objaviti Milanovićev ispravak. ${ }^{150}$

Wilfan odgovara u Edinosti da nije točno da je istarski širi odbor sazvao za 27. srpnja, vjerujući da je riječ samo o tiskarskoj pogrešci u Goriškoj straži

146 S obzirom na izvješćivanje Pučkoga prijatelja, riječ je o Josipu Grašiću, župniku iz Berma.

147 Nezadovoljna izvješćivanjem Edinosti, spominje Goriška straža i to da je službeno glasilo bacilo u koš niz dopisa, „podpisanih celo od 15 izobražencev brez razlike na barve. Tako ne pojde dalje. Absolutizem in diktaturo vlade moramo prenašati, ker se ga pač ne moremo otresti, domačega apsolutizma ne bo ljudstvo trpelo. Treba bo iskati kak izhod. V Istri je napravil dr. Stanger razkol. Žalostno, a resnično. Bog daj mirne rešitve iz mučnega položaja.“ „Težka kriza v Istri“, Goriška straža, 18. julija 1922.

148 „Poziva se novoizabrani širi odbor istarskog Pododbora Političkog društva Edinost na sastanak, koji će se održati u prostorijama Uredništva Edinosti u utorak 25. t. mj. u 10 1/2 sati s dnevnim redom: 1. konstituiranje odbora i izbor užeg odbora; 2. slučajnosti. Božo Milanović, ex-predsjednik.“ „Vesti iz Istre“. Edinost, 14. julija 1922.

149 „Budući, da nuždno treba, da se novoizabrani odbor našega Političnoga društva čim prije konstituira te javi vlasti, i budući da je sjednica u tu svrhu već sazvana za ponedjeljak, 17. t. m., u 3 pop., učtivo molim članove širega odbora za Istru, da se sastanu, kako je bilo prvo dogovoreno, isti dan, 17. t. m. u 10 1/2 pr. p. Dr. Josip Wilfan kao preds. Pol. dr. 'Edinost'.“,Vesti iz Istre. Sastanak istarskog šireg odbora“, Edinost, 15. julija 1922.

150 „Milanović je hotel priobčiti v 'Edinost' stvaren popravek, a gospodarji dnevnika, so to objavo prepovedali.“ „Težka kriza v Istri“, Goriška straža, 18. julija 1922. 
(„kar je, upam, zgolj tiskovna napaka“). Objašnjava da je, iako je sastanak Milanović sazvao za 25. srpnja, morao pomaknuti datum jer se odbor izabran na skupštini Političkoga društva Edinost 11. srpnja morao konstituirati čim prije te to prijaviti vlastima u zakonitom roku, za koji je mislio da traje osam dana. Međutim, pregledavši zakon, ustanovio je da rok iznosi samo tri dana („kdo naj vse drži v glavi!“). U odboru je Istranima osigurano devet mjesta, koja su bila na skupštini također stvarno privremeno zauzeta, ovisno o odobrenju širega istarskog odbora. Kako je kao predsjednik cjelokupnoga novog odbora Političkoga društva Edinost želio sazvati njegovu prvu sjednicu, i zbog navedenoga zakonitog roka svakako prije 19. srpnja, a rečeno mu je da su članovi širega istarskog odbora zamijenjeni sastankom 17. srpnja ujutro, ${ }^{151}$ odredio je sjednicu cijeloga odbora za isti dan poslijepodne. Pozivi su odmah poslani. Međutim, budući da je Milanović kao bivši predsjednik Istarskoga pododbora bez njegova prethodna znanja objavio poziv širem odboru za 25. srpnja, ${ }^{152}$ bio je prisiljen, jer je bilo vrijeme prekratko i jer bi mu se inače izjalovilo konstituiranje novoga odbora 17. srpnja, objaviti u Edinosti od 15. srpnja zahtjev da se širi istarski odbor sastane kako je prije dogovoreno, 17. srpnja ujutro. Wilfan priznaje da je zabranio objavu Milanovićeva ispravka jer bi se on imao objaviti u Edinosti od 16. srpnja, dan prije sastanka širega istarskog odbora i prve sjednice novoga cjelokupnog odbora Političkoga društva Edinost. I sastanak širega istarskog odbora i sjednica novoga odbora Edinosti bili su prava mogućnost da se sa svih strana izgovori „pomirjevalna in svarilna beseda“. U tom je smislu, piše Wilfan, namjeravao govoriti, i govorio je 17. srpnja. ${ }^{153}$

Nakon Wilfanova objašnjenja, za dva dana izlazi tekst u Edinosti s vidljivom namjerom ublažavanja napetosti, pribojavajući se protivnika s talijanske strane. ${ }^{154}$ Ali stavovi su se već toliko radikalizirali da i konstituiranje

151 Sporan, indikativan podatak, i sigurno da se mora povezivati s podatkom Goriške straže da su se voditelji istarske organizacije ranije prijateljski sporazumjeli, ali da je Stanger sporazum razvrgnuo jer je sastavio odbor po svojoj volji (,,Za volitve v novi odbor so se bili voditelji prej prijateljsko sporazumeli; ta sporazum je dr. Stanger ovrgel, ker je sestavil odbor po svoji volji.“ „Težka kriza v Istri“, Goriška straža, 18. julija 1922.). Ova konstatacija nije precizirana, ali u daljnjoj polemici između glasila stvari postaju jasnije. U Kozini je izabran širi odbor od 24 člana, od kojega se trebao konstituirati novi Istarski pododbor. Taj će širi odbor biti promijenjen, sastat će se 17. srpnja dopodne kada će se konstituirati novi Istarski pododbor od 9 članova, a poslijepodne cjelokupni novi odbor Političkoga društva Edinost koji je sačinjavalo ukupno 18 članova.

152 U tekstu piše „27. t. m.“, što je sigurno tiskovna pogreška.

153 Josip Wilfan, „V pojasnilo“, Edinost, 21. julija 1922.

154 „Vprašamo našo široko javnost: Ali je kaj takega res treba? Ali ni med moži dobre volje edino primerno, da se dogovorita o sestanku in da bi v tem primeru g. Milanović poskočil k g. dr. Wilfanu, ki je, če ne drugo, starejši, posebno ko sta oba v Trstu? Pa recimo, da stvar ni tako važna, da je treba prej velikih posvetovanj, ali je potrebno, da se taka ničeva zadeva vlači v javnost ter da se prisili naše može, kakor 
novoga Pododbora u kojem će se nalaziti i pripadnici kršćanskih socijalista i pripadnici liberala neće ublažiti stvarne razlike već stanje kreće prema raskolu Istarskoga pododbora. Premda se - iščitavajući novinska glasila uočava da postoji i svijest o potrebi jedinstvenoga djelovanja, ono se neće održati, pogotovo kada je uskoro, krajem kolovoza 1922. liberalna skupina pokrenula Staru našu slogu. ${ }^{155}$

Reagiranja na konstituiranje novoga Istarskog pododbora sve više ukazuju na akcije zakulisnoga djelovanja. Primjećuje se to u reagiranju Pučkoga prïatelja na članak u Edinosti od 23. srpnja. Autor članka objašnjava da je Istarski pododbor imao svojega predsjednika koji je kroz godinu dana sazivao sjednice sasvim samostalno, a da mu nitko nije prigovarao, pa ni predsjednik Političkoga društva Edinost Josip Wilfan. Uobičajeno je da stari predsjednik obavlja svoju dužnost sve dok se ne izabere novi, zato je Milanović sazvao sjednicu istarskoga šireg odbora za 25. srpnja pozivom u Edinosti u svrhu konstituiranja novoga odbora. Kad je već bio odaslao poziv Uredništvu Edinosti, došao je 13. srpnja k njemu tajnik Pododbora da mu priopći kako su on i potpredsjednik ${ }^{156}$ već sazvali širi odbor za 17. srpnja. Milanović mu je, piše Pučki prijatelj, obrazložio kako je za mnoge članove nemoguće doći u tako kratkom roku. Primjedba se čini utemeljenom jer se radi o 24 člana širega istarskog odbora, ${ }^{157}$ koji zasigurno nisu svi boravili u blizini Trsta već su morali doći s veće udaljenosti. Glasilo nastavlja da je Milanoviću tajnik Iveša „napokon rekao, neka dakle sazove on sjednicu za 25. t. mj.“. Tako je sljedećega dana, 14. srpnja, tiskan poziv u Edinosti za sastanak 25. srpnja. Međutim, bez Milanovićeva su znanja tajnik i potpredsjednik sazvali sastanak za 17. srpnja, dapače su pozvali pismeno i njega. Nakon toga je Wilfan „zamolio“ članove pozivom u Edinosti od 15. srpnja da dođu na sjednicu 17. srpnja. Jasno je - navodi autor teksta u Pučkom prija-

dr. Wilfana in dr. Slavika, ki imajo dražega dela, da morajo obelodaniti take popravke, kot smo jih čitali v petkovi 'Edinost'? Ne, bratje, tako ne gre, tako ne bo šlo naprej. Naj Vas spominjamo na dogodek, ki se je zadnje dni odigral v italijanskem taboru: $\mathrm{V}$ tržaškem mestnem svetu je prišlo pretekli torek do hudih prerekanj med posameznimi člani italijanske nacionalne večine. Letele so ostre besede, huda očitanja, celo kaka psovka. In kaj se je zgodilo? Predno so se razšli, še v isti seji, se je vzdignil mož ter predlagal, naj se omenjeni incident ne zapiše v stenografični protokol ter naprosil časopisje, naj o njem molči. In tisti, ki so se malo prej prerekali, ki so si lučali celo psovke v obraz in si hoteli skočiti v lase, so složno vzdignili roke kvišku in sklenili, da se družinsko umazano perilo da na tihem perici, ne pa da se obesi na dolgi drog javnosti. In - italijansko časopisje, ki ni obvezano po sklepih mestnega sveta, se je tega sklepa točno in vestno držalo!“” „Ne tako, bratje!“, Edinost, 23. julija 1922.

155 Milanović, „,Tršćanska hrvatska štampa između dva rata s osvrtom na Istru“, 139-140; Iveša, „Tršćanska hrvatska štampa između dva rata“, 150-151; Željko Klaić, „Prilozi o 'Staroj našoj slogi’ i ‘Istarskoj riječi’ (1922, 1923. i 1924)“, Jadranski zbornik,14, 1990-1991., 161-167.

156 U korištenom tisku nisam naišao na konkretan podatak navođenja imena i prezimena potpredsjednika. 157 Nisam uspio utvrditi imena svih članova šrega istarskog odbora. 
telju - da je takvo postupanje potpredsjednika i tajnika ignoriranje Milanovića, tim više što on stanuje u Trstu pa su se lako mogli dogovoriti s njime osobno ili telefonom. ${ }^{158}$ Nastavlja da je „bilo razloga za mišljenje“ da su tajnik i potpredsjednik „tako sami uredili iz posebne tendencije“ kako bi lakše ostvarili svoje ciljeve kod konstituiranja novoga odbora zbog pomanjkanja nekih članova, za koje da su sami priznali da 17. srpnja neće moći stići na vrijeme. Napominje da razlog da su se odbornici morali prijaviti vlastima do 17. srpnja ne stoji jer je rok istekao već 14. srpnja. Ipak, bez obzira na sve to, bivši predsjednik Milanović došao je na sjednicu 17. srpnja i popustio zbog sporazuma i mira, iako su „tako mnogi članovi bili lišeni svog prava“ sudjelovanja kod konstituiranja novoga odbora. ${ }^{159}$

Novi Pododbor Političkoga društva Edinost za Istru konstituirao se ovako: Mirko Vratović, predsjednik; Božo Milanović, potpredsjednik; Ivan Stari, tajnik i blagajnik; odbornici: Marijan Tomašić, Tomo Herak, Alojzij Kraševec, ${ }^{160}$ Ivo Sokolić, Marko Zlatić i Bogomil Medvešček.

Dok se odvijala polemika oko konstituiranja novoga odbora i oko načina na koji se to odvijalo, u glasilima se raspravljalo o skupštini u Kozini, o sadržaju oko kojega su se sukobljavale suprotstavljene strane. Bez obzira na konstituiranje Istarskoga pododbora 17. srpnja, u kojem su se nalazili pripadnici obje idejne struje, polemika se u glasilima nastavila zaoštravati.

\section{Polemike nakon konstituiranja novoga Pododbora}

Povodom izvješćivanja Pučkoga prïatelja i Goriške straže o izjavi poslanika Stangera na skupštini u Kozini „da je istarska organizacija antiklerikalna, da je strogo liberalna“, piše tršćanska Edinost da će se Stanger sam znati braniti. ${ }^{161}$ Dopisnik Edinosti objašnjava da se drugi dio članka u Edinosti

158 Ovo je zasigurno reakcija na prethodni članak u Edinosti, kada je komentirano da je Milanović mogao svratiti do Wilfana. Vidi bilj. 154.

159 „Odgovor listu 'Edinost'. I mi velimo: Ne tako, braćo!“, Pučki prijatelj, 27. srpnja 1922.

160 Alojzij Kraševec / Vjekoslav Kraševac, tada župnik u Brezovici. Kacin-Wohinz, Narodnoobrambno gibanje primorskih Slovencev v letih 1921-1928, I, II, 160, 168-169, 171, 557, piše Vjekoslav Kraševac, a Barbalić, Vjerska sloboda Hrvata i Slovenaca Istri, Trstu i Gorici, 79, piše Vjekoslav Kraševec. Lojze Škerl, „Kraševec Alojzij“, Primorski slovenski biografski leksikon, 8. snopič, ur. Martin Jevnikar, Gorica 1982., 187-188. Marko Medved, „Župe riječke biskupije tijekom talijanske uprave“, Riječki teološki časopis, 17, 1, 2009., 132, piše Alojzij Kraševec.

161 „Povdarjamo tu le toliko, da Istran sploh in istrski narodni poslanec še posebej kaj takega ne more reči, povemo le toliko, da smo od več oseb, ki so bile navzoče pri zborovanju na Kozini, in ki so po zdravem razumu, katerega im je bog dal, in po svoji izobrazbi absolutno sposobne, da izrečeno misel razumejo tako, kakor je bila mišljena, slišali potrdilo, da dr. Stanger, misli, ki mu jo podtikata 'Pučki Prijatelj' in 'Goriška Straža', sploh ni izrekel. Daleč smo od tega, da bi se spuščali v skolastično ali jezuitsko razlaganje in igranje z besedami; kakor rečeno, pričakujemo lahko z gotovostjo pisano izjavo dra. Stangerja, in tam 
od 15. srpnja, kada je glasilo izvješćivalo o skupštini u Kozini, ${ }^{162}$ odnosi na predmet unutarnjega preustroja političke organizacije. $U$ vezi s tim su pitanjem iznesena dva suprotstavljena prijedloga. Dio skupštinara, na čijem su čelu bili Virgilij Šček, Ivan Vouk i Šime Frulić, htio je imati samostalno društvo za Istru, a dio skupštinara koje su predvodili Ulikse Stanger, Luka Kirac, Fran Flego ${ }^{163}$ i drugi, bio je za to da Istra ostane u zajedničkoj organizaciji s Trstom. Tvrdi se da su i jedna i druga mogućnost dobre, samo ako je dobra volja, ozbiljan rad i ako ima sposobnih radnika. Dopisnik navodi da je istarska javnost svjesna da nema dovoljno aktivista da bi se mogla uzdržavati vlastita samostalna politička organizacija te da Istra i Istrani, dok ne steknu dovoljan broj potrebnih radnika, formalno neće biti odvojeni od Trsta. ${ }^{164}$ Piše i da je većina učitelja i seljaka bila protiv samostalnoga društva. Učitelj Ivan Vouk, koji je podupirao samostalno društvo, nije od dopisnika Edinosti prikazivan kao npr. Luka Kirac, koji je bio za jedinstvo s Trstom: tumači da glas kojim je Vouk davao potporu samostalnom društvu nije bio tako istarski kao glas Kirca, koji je bio za jedinstvenu organizaciju s Trstom. ${ }^{165}$ Petru Sironiću priznaje da je častan čovjek, ali mu pridaje lokalni značaj. ${ }^{166}$

Odgovarajući na pisanje Edinosti od 23. srpnja, autor članka u Pučkom prïatelju od 27. srpnja piše da je na sastanku u Kozini manjina, koja „zastupa mišljenje preogromne većine istarskog pučanstva, bila prisiljena otići“ jer se nasilnim i neprestanim prekidanjem i vikanjem nije dopuštalo mnogima govoriti te su padale uvrede protiv Pučkoga prijatelja i Tiskovnoga društva u Pazinu, protiv svećenstva i protiv vjere. Međutim, Edinost je izvijestila

bomo videli v zapisanih besedah misli in nazore našega poslanca. Za sedaj opozarjamo le na popravek, ki ga je poslal dr. Stanger 'Eri Nuovi' in ki smo ga objavili četrtkovi 'Edinost' (vidi bilj. 114; op. Ž. K.) in kateri gotovo ne diši ne po liberalizmu ne po klerikalizmu in še najmanj po razkolu“. „Ne tako, bratje!“, Edinost, 23. julija 1922.

162 Misli se na: „Glavni sestanek istrskih članov Pol. društva 'Edinost’ v Kozini“, Edinost, 15. julija 1922.

163 Kada se Pučki prijatelj od 27. srpnja osvrtao na ovo pisanje, da se pored inih i Fran Flego zalagao da Istra ostane u organizaciji s Trstom, onda naglašava da Flego nije predlagao zajedničku organizaciju s Trstom nego da je izjavio da mnogi prisutni nemaju pravog pojma o tom pitanju. „Odgovor listu 'Edinost'. I mi velimo: Ne tako, braćo!“, Pučki prijatelj, 27. srpnja 1922.

164 „Saj če bo enkrat imela Istra dovolj dobrih in voljnih delavcev, je naravno, posebno z ozirom na spravljivost, razsodnost in narodno gorečnost tržaških krogov, da bodo Istrani uživali popolno samostojnost, tudi če formelno ne bodo ločeni od Trsta. Šlo je na Kozini le za zunanjo obliko, dobra volja je bila pri vseh, a gotovo najboljša volja tudi pri tistih, ki niso hoteli samostojnega društva“. „Ne tako, bratje!“, Edinost, Trst, 23. julija 1922.

165 Reakcija u Pučkom prijatelju na ovo pisanje o Vouku i Kircu: „Pisac spominje, da glas Vouka nije bio tako istarski kao glas župnika Kirca, a zaboravlja, da je Vouk živio u Trstu te je poznavao mnogo bolje prilike, koje o tom pitanju odlučuju, nego župnik Kirac“. „Odgovor listu 'Edinost'. I mi velimo: Ne tako, braćo!“, Pučki prijatelj, 27. srpnja 1922.

166 „Ne tako, bratje!“, Edinost, 23. julija 1922. 
kao da se većina lijepo vladala i kao da je skupština protekla u najboljem redu. Razlog da se Istra mora osloniti na Političko društvo Edinost u Trstu „jer da sama nema dovoljno narodnih radnika“ nije utemeljen jer ni u Trstu nema ljudi na koje se Istra može osloniti: Josip Wilfan je i previše zaokupljen drugim općim poslovima, a Edvard Slavik zbog starosti i bolesti već teško obavlja svoje kancelarijske poslove. Za samostalnu istarsku organizaciju govore razlozi zbog kojih je bivši predsjednik Milanović potaknuo osnivanje Istarskoga pododbora te mu pronašao prostorije i činovnike, a upravo su mu se tršćanski „radnici“ puno protivili. Ova tvrdnja novinara Pučkoga prijatelja važan je pokazatelj da su se već prilikom utemeljenja Istarskoga pododbora iskazale nesuglasice među nacionalnim aktivistima. Autor upućuje izravno na zakulisne postupke tvrdnjom da je svađa koja se dogodila bila dobro proračunata, „importirana izvan našeg Primorja“. ${ }^{167}$

Članak u Pučkom prijatelju od 27. srpnja predstavlja vrhunac izražene oštrine u prikazivanju pisanja o skupštini u Kozini 10. srpnja 1922. Međutim, u istom broju glasila informiraju se dopisnici o pokrenutoj akciji za izmirenje. Obavještavaju se dopisnici iz Opatije, Podgrada, Buzeta, Pazina, Motovunštine, Puljštine i Maloga Lošinja da se nisu mogli uvrstiti njihovi dopisi o istarskoj krizi ,jer smo morali zadržati sve obranbene napadaje“, dok je u tijeku akcija za izmirenje koja je bila pokrenuta posljednjih dana. Nadaju se da će nastali spor biti riješen mirnim putem pa da više neće biti potrebno „ništa iznašati u javnost“. ${ }^{168}$

Nakon što je već trajala akcija za izmirenje, uslijedila je reakcija Edvarda Slavika u Edinosti od 30. srpnja na pisanje Pučkoga prïatelja od 27. srpnja, u kojoj je tvrdio da je Božo Milanović autor toga članka i da nije točno ono što je o njemu napisao. ${ }^{169}$ Milanović je reagirao u Pučkom prijatelju od 10. kolo-

167 „Odgovor listu 'Edinost'. I mi velimo: Ne tako, braćo!“, Pučki prijatelj, 27. srpnja 1922.

168 „Dopisnica Uredništva“, Pučki prijatelj, 27. srpnja 1922.

169 „V 'P. P.' od 27. t. m. ste blagovolili pisati o meni, da radi starosti in bolezni težko opravljam svoje pisarniške (mislili ste najbrže odvetniške) posle. Kako znam, da ste Vi pisec onega članka? E, delo izdaja mojstra! Kaj takega zmorete samo Vi, gospodine Božo! 'O mein lieber August in, alles ist hin', sem si zapel (še pojem, gospodine Božo, vkljub visoki starosti svoji in bolezni). Ko sem pa dospel do mesta, kjer pravite, da imate za vse svoje trditve trdne dokaze, sem klonil glavo in zapel otožno: 'In zda? pa nikdar več! ' - - Mila pesem je nekoliko utešila mojo bol, a tedaj se je pojavila jeza v mojem srcu nad tistim, ki je meni in javnosti predočil mojo mizerijo. Toda takoj se mi je prikazala pred očmi Vaša mila slika. Videl sem Vas prav tako pred sabo v istem trenutku, ko ste mi v četrtek zvečer, ko je bil oni Vaš članek že v tisku, rekli v najnaravnejšem, resnem tonu, da v njem ni napadov na nobeno osebo, — in tedaj sem vzkliknil: 'O bog, odpusti mu, saj ne.. . misli slabo!' Kaj ne, gospodine Božo, da to ni noben napad? Starost, bolezen, onemoglost to ni nobena sramota! To je le nesreča, velika nesreča!! In nič drugega! Gorje sicer tistemu revežu, ki ga vse te smole zadenejo, ta je 'lifran’ za vse svoje življenje! — A sramota to ni! Torej ne gre za napad na osebo - kaj ne da ne, dobri gospodine Božo? Sicer bi mi vse to utegnilo škoditi in me diskreditirati v javnosti. Kedo bo hodil po pravno pomoč k bolnemu obnemoglemu starcu? Kedo ga bo še upošteval? Kaj ne, gospodine Božo, Vi ste preveč inteligentni in študirani, da ne bi spoznali posledic 
voza, naglašavajući da on nije autor članka. ${ }^{170}$ Raspravljanje oko skupštine u Kozini u njihovim pismima nije bilo u prvom planu; Slavikova reakcija i Milanovićev odgovor imaju temelj u pitanju istarske političke organizacije, s tim da se u pismima očituje prijelaz na osobnu razinu. Reagiranja koja će uslijediti u tisku neće imati u prvom planu skupštinu u Kozini, očito zbog pokušaja pomirbe, a u Pučkom prijatelju isticat će se članci kojima se poziva na izmirenje i zajedničko djelovanje. ${ }^{171}$

Prema istraživanju Vjekoslava Bratulića, liberali se nisu mogli pomiriti s time da na jedini tada hrvatski list u Istri ne mogu utjecati. Tražili su da ga preuzme Pododbor Političkoga društva Edinost za Istru, u kojem su imali predsjednika i tajnika, tj. imali ih od 17. srpnja. Tiskovno društvo u Pazinu i Božo Milanović, potpredsjednik Pododbora od 17. srpnja, odbacili su prijedlog liberalne skupine. Na to su liberali odlučili pokrenuti list Stara naša sloga. Saznavši za to, „klerikali“ su pokušali spriječiti izdavanje lista pa su u tu svrhu preko Virgilija Ščeka i Engelberta Besednjaka pokrenuli posredovanje kod Wilfana i Stangera da list ne iziđe. Pojavili su se kao mandatori Tiskovnoga društva i tražili obustavljanje lista jer bi njegova pojava

tega svojega dejanja! Vi ste vedeli za vse to, in vendar ste storili! Zakaj? Radi stvari, radi dobre stvari ste se $s$ težkim, krvavečim srcem odločili k temu. Morali ste! Kaj ne da, gospodine Božo? Vsakemu mora biti jasno, da drugače ni bilo mogoče dokazati, da se Istra mora ločiti odi Trsta, ker sta tam samo dva moža: dr. Wilfan, katerega je škoda obremeniti z istrskimi malenkostmi in dr. Slavik, kateri radi starosti in bolezni niti gibati ne more. Toda potolažite se, dobri gospodine Božo, ni tako hudo z mano! Še vedno pojem, se radujem v veseli družbi, lahko opravljam vsa pisarniška in celo odvetniška dela, delam in zalivam s teškimi škropilnicami na svojem vrtu in tudi apetit imam dober — pa še vedno koga zafrknem. Le tega prosim Boga, da bi mi dal dovolj dobrih živcev, da bi mogel prenašati nekega soborca. V Trstu, dne 29. julija 1922. Dr. Edvard Slavik, ki bi rad bil odvetnik, pa ne more.“ „Prečastitemu gospodu dr.du teol. Božu Milanoviću pri Sv. Ivanu“, Edinost, 30. julija 1922.

170 „Otvoreno pismo Veleučenom gospodinu Dru. Eduardu Slaviku, odvjetniku u Trstu. Pročitao sam, gospodine doktore, u 'Edinost' od 30. pr. mj. Vaše otvoreno pismo, kojim ste se velikom ironijom i zafrkavanjem oborili na mene u preko 60 redaka zbog dvije riječi, kojima je netko u 'Pučkom Prijatelju' samo spomenuo Vašu starost i bolest, premda nijesam ja za te riječi odgovoran i premda je očito, da Vas pisac onog temeljitog članka nije mislio uvrijediti, jer inače ne bi bio odmah pred tim riječima spomenuo, da ste 'preopterećen narodnim radom'. Obratili ste se dakle, gospodine doktore na krivu adresu. Smatrali pak ste potrebnim, da tim otvorenim pismom javite meni i svoj javnosti, da još uvijek pjevate 'uza svu visoku starost svoju i bolest', a naročito pjesmu 'O mein lieber Augustin', da 'zalijevate teškim škropionicama', da imate 'dobar apetit', da vam se katkada prikaže koja 'mila slika pred očima', 'da zafrkavate', da se 'radujete u veselom društvu' itd. Na to i ostalo ne mislim Vam odgovarati, jer ste si tim pismom odgovorili sami potvrdiv ono, što ste mislili pobiti. Javljam Vam samo, da me Vaša zafrkavanja ne mogu boljeti, jer veličina boli zbog naših općenitih nevolja ne dopušta mjesta boli zbog sitnica i djetinjarija. Ja u vrijeme, kad naš narod propada, ne mogu se podavati radovanju u veselom društvu, a nemam niti vremena za to, osobito ne za zafrkavanja i uopće za provadjanje tako neozbiljnog života, kako ga sam o sebi opisujete Vi, koji ste smatran jednim od dva glavna tršćanska narodna radnika, na koje bi Istra u prvom redu 'morala' osloniti svoju polit. organizaciju. Drugi put, gospodine doktore, pazite bolje, da ne pogriješite adresu onoga, koji ima postati predmetom Vaše ironije i zafrkavanja. Inače prelazim preko toga, jer imam ozbiljnijeg posla i korisnijeg za našu narodnu stvar te ne želim biti medju onima, koji se skrbe za Istru - po kavanama i 'betulama’. U Trstu, dne 9. kolovoza 1922. Božo Milanović“, Pučki prijatelj, 10. kolovoza 1922.

171 Jedan članak u tom smislu može biti karakterističan: „Braćo, Istra nas zove - prenimo se!“, Pučki prijatelj, 5. kolovoza 1922 . 
prouzročila raskol u Istri, ali intervencija nije uspjela. ${ }^{172} \mathrm{U}$ namjeri posredništva oko izdavanja Stare naše sloge tražila se i intervencija kod Matka Laginje u Zagrebu. ${ }^{173}$

Krajem kolovoza 1922. počelo je izlaziti novo glasilo Stara naša sloga, što je izazvalo iznenađenje i ogorčenje istarskih kršćanskih socijalista i Pučkoga prijatelja. ${ }^{174}$ Pokretanje novoga glasila je svakako bilo legitimno, ali je pokretanje pod tim nazivom bilo dvojbeno jer se Uredništvo pozivalo na kontinuitet s Našom slogom te na Jurja Dobrilu i njezina dugogodišnjega urednika Matka Mandića. ${ }^{175}$ Sve ukazuje na to da je sukob poprimio nestvarne relacije s obzirom na ideju nacionalne sloge afirmiranu u prethodnim desetljećima. Međutim, treba reći da je to hrvatsko glasilo, kao i oni koji su ga pokrenuli, dalo značajan prilog prateći i prikazujući stanje u kojem se nalazilo hrvatsko stanovništvo u istarskoj pokrajini, pa je značajan izvor i pokazatelj sveukupnih ondašnjih društvenih prilika u relativno kratkom vremenu izlaženja. ${ }^{176}$

Pokretanje novoga glasila vodilo je prema odvajanju istarskih socijalnih kršćana i namjeri obnavljanja rada i djelovanja nekadašnjega Političkog društva za Hrvate i Slovence u Istri u listopadu 1922. Pokušaj obnove rada Političkoga društva također je bio legitiman, ali je pokretanje rada u nacionalno-političkom, gospodarskom i kulturnom smislu u godinama koje su uslijedile pod fašističkim pritiskom bilo teško ostvariti. Volja i optimizam izraženi na skupštini Političkoga društva 12. listopada 1922. bili su očiti, ali će i sami pokretači uvidjeti da će uz dotadašnje fašističko nasilje u Istri, a potom i dolaskom fašista na vlast u državi, javno djelovanje na terenu u Istri biti teško ostvarivo.

\footnotetext{
172 Bratulić, „Političke stranke u Istri 1918-1923“, 188-189.

173 Željko Klaić, „Matko Laginja između narodno-liberalne i kršćansko-socijalne struje u Istri, s osvrtom na položaj hrvatskog tiska (1918.-1928.)“, Zbornik Društva za povjesnicu Klana, 4, 1998., 43-46.

174 „Nova istarska nesloga“, Pučki prijatelj, 7. rujna 1922.

175 U prvom broju tjednika od 31. kolovoza 1922., u članku Uredništva „Dvije riječi našim ljudima u Istri“ između ostalog stoji: „Mili narode, U 'Našu Slogu’ pisali su od davne davnine uz našega Velikoga Oca Jurja Dobrilu i mnogogodišnjeg urednika pok. prof. Matka Mandića, svi naši narodni prvaci. U njihovu duhu i imenu njihovu mi ćemo i unaprijed uredjivati ovaj naš stari i dragi list. Jedno obećajemo već danas našim čitateljima, a to je, da 'Naša Sloga' ne će ni u kojem slučaju iznositi naše možebitne domaće prepirke, jer bi od toga samo neprijatelji imali koristi i zabave. Mi ćemo u ovom našem listu iznositi samo ono, što naš narod mora, da zna, i što će mu biti od najpreče potrebe. Vremena su vrlo teška; ne znamo, što nas čeka, zato i treba, da se narodu govori samo o stvarima, koje su mu bliske i srcu i duši i koje će mu svijetliti um i jačati svijest, da bilo sam bilo pomoću zauzetih narodnih ljudi nađe sebi stalno putove svojoj sreći i blagostanju."

176 Klaić, „Prilozi o ‘Staroj našoj slogi’ i ‘Istarskoj riječi’ (1922, 1923. i 1924)“, 161-167.
} 


\section{Pučki prijatelj i skupština Političkoga društva za Hrvate i Slovence u Istri 12. listopada 1922. u Trstu}

Pučki prijatelj je izvijestio da je skupština Političkoga društva za Hrvate i Slovence u Istri održana 12. listopada 1922. uz komentar da se povijest ponovila: jednom su se već Istrani i Tršćani nalazili u istoj političkoj organizaciji, ali su Istrani poslije bili uvidjeli da je bolje ako se od Trsta odvoje i da se združe u posebnom političkom društvu za samu Istru. Stoga su 12. listopada oživjeli svoje staro političko društvo na glavnoj skupštini, održanoj u Trstu. List „iz razumljivih razloga“ nije prethodno objavio saziv skupštine, ali se ipak po čitavoj Istri javilo „malne u svaku općinu“. Tko je želio dobiti poziv, a nije ga možda dobio s obzirom na postojeće prilike, neka ne zamjeri: „Kasnije će se sve urediti.“ Izvjestitelj navodi da je, bez obzira na nevrijeme koje je toga dana zahvatilo čitavu Istru, skupština bila dobro posjećena i da su po povjerenicima bili zastupljeni svi dijelovi Istre i otoka.

Skupštinu je otvorio zrenjski župnik Šime Červar ${ }^{177}$ i održao govor o potrebi stvaranja vlastite političke organizacije jer da je rad Političkoga društva Edinost zanemaren u pogledu Istre. ${ }^{178}$ Potom su skupštinarima pročitana pozdravna pisma u kojima se daje podrška obnavljanju rada i djelovanja Političkoga društva za Hrvate i Slovence u Istri. Pozdravno pismo s izrazima potpore skupštini je uputio Seljačko-radnički savez u Gorici, ${ }^{179} \mathrm{a}$

177 Svećenik Šime Červar bio je istaknuti istarski narodnjak. Kao župeupravitelj u Grožnjanu naveden je na Popisu članova prijavljenih Političkom društvu za Hrvate i Slovence u Istri utemeljenom u Pazinu 1902. Ubrzo prelazi u Zrenj gdje će biti dugogodišnji župnik. Kao odbornik Političkoga društva izabran je na skupštini 20. lipnja 1912. u Puli. Kao kandidat Političkoga društva za Hrvate i Slovence u Istri bit će izabran u Istarski sabor 1908. i 1914. U vrijeme raspada Austro-Ugarske, u studenom 1918., uhićen je i odveden u Trst, gdje je u zatvoru odsjedio 15 dana. U novoj talijanskoj državi, za izbornih dana za parlament u Rimu, 14. svibnja 1921. došlo je iz Poreča u Zrenj 20 fašista. Napali su župnika, demolirali mu stan, pokućstvo, knjižnicu i druge stvari te pobacali kroz prozor i spalili. Bacili su ga u teretni automobil i opet iz auta na cestu. Istukli su ga i izbili mu četiri zuba. Odvezli su ga u Motovun, gdje su ga u zatvoru mučili i tukli, i gdje je ostao zatvoren mjesec dana. Istražni sudac protiv njega kao protivnika države bio je onaj fašist koji ga je prethodno putom tukao i pljuvao. O Šimi Červaru: „Puljsko-rovinjski kotar: Glavna skupština političkog društva za Hrvate i Slovence u Istri.“, Naša sloga, 27. lipnja 1912.; „Jedna pedesetogodišnjica“, Pučki prijatelj, 23. listopada 1924.; Barbalić, Vjerska sloboda Hrvata i Slovenaca u Istri, Trstu i Gorici, 45-46; isti, Narodna borba u Istri od 1870. do 1915. godine, 122, 173; Radetić, Istra pod Italijom 1918-1943, 84-85; Milanović, Hrvatski narodni preporod u Istri, II, 146-147, 162-163, 304; isti, Istra u 20. stoljeću, 1, 104-106 Klaić, „Nacionalni pokret istarskih Hrvata i Slovenaca“, 53-54, 81-82.

178 „Ne mi svećenici, nego Laginja, Spinčić i pok. Mandić i drugi vrijedni rodoljubi zagovarali su i proizveli odijeljenje od Trsta. Tu misao nisu zagovarali samo Istrani, koji su stanovali u Istri, nego i pok. Mandić, koji je stanovao u Trstu, a bio je poštenjak od pete do glave. (...) Trst je grad trgovački, kapitalistički, a Istra je agrarna zemlja. Istra je uvijek bila nazivana siroticom, a da li će više ili manje ostati i nadalje takva, to je bar donekle i od nas samih odvisno.“ „Glavna skupština 'Političkog društva za Hrvate i Slovence u Istri' u Trstu. Historija se ponavlja: Istra hoće da se opet podigne na vlastite noge.“, Pučki prijatelj, 19. listopada 1922.

179 „Zato izjavljujemo, da nema gorih zločinaca za naš narod, nego li su oni, koji bi htjeli uništiti čvrsti vez, koji veže istarsko seljaštvo sa njegovim svećenstvom.“ (...) „Zato smo uvjereni, da će “Političko društvo za Hrvate i Slovence u Istri' biti ona tvrdjava, u kojem će se naše seljaštvo zajedno sa svojim svećenstvom, učiteljstvom i drugim staležima boriti za životna prava gažene slavenske Istre. I to je prava sloga, prava 
pročitana su i pisma podrške raznih pojedinaca i skupina seljaka iz raznih istarskih krajeva. Zatim je pročitano pismo Engelberta Besednjaka, zemaljskoga odbornika u Gorici, koji je podržao skupštinu, ${ }^{180}$ a preneseni su i pozdravi inženjera Josipa Rustje. ${ }^{181}$

Prešlo se na drugu točku dnevnog reda, izbor novoga Odbora. Župnik Alojzij Kraševec predložio je da u Odbor Političkoga društva uđe 14 pojedinaca iz raznih krajeva Istre i iz raznih staleža, pogotovo iz redova seljaštva, što je prihvaćeno. Za predsjednika je izabran Šime Červar, za potpredsjednika Petar Sironić iz Trviža, a za tajnika Ivan Vouk.

U trećoj se točki dnevnoga reda raspravljalo o mogućnosti promjene nekih pravila, s obzirom na nove političke prilike, što je prepušteno novom Odboru, uz naputak da duh pravila mora ostati isti. Sjedište je Političkoga društva premješteno iz Pazina u Trst, a godišnja članarina iznosi dvije lire i to za sve članove. Pri kraju skupštine - poslije treće točke dnevnoga reda - predsjednik Červar morao je otići pa je predsjedavao Liberat Sloković, također stari odbornik Političkoga društva. ${ }^{182}$

Prešlo se na posljednju točku dnevnoga reda, slučajnosti (tj. razno). Javio se za rïječ prijašnji predsjednik Istarskoga pododbora Edinosti, Božo Milanović, koji je obrazložio uzroke koji su ih prisilili da se odijele od tršćanske organizacije i okupe u vlastitom istarskom društvu. Poslanik u rimskom

zajednica svih poštenih sila u narodu.“ (...) „Kroz oluju tih mračnih dana vodit će jedinstveni narod stara organizacija, kojoj su dali ideju biskupi Dobrila i Mahnić i za koju je radio čitavi red narodnih boraca." Na istom mjestu. Tajništvo Kmečko-delavske zveze vodio je pravnik i političar Josip (Jože) Bitežnik, jedan od prvaka goričkih kršćanskih socijalista i ovdje jedan od potpisnika pozdravnoga pisma. O Josipu Bitežniku: Kacin-Wohinz, Narodnoobrambno gibanje primorskih Slovencev v letih 1921-1928, I, II, 33, 36-37, 41-42, 135, $151,153,158-159,173,190,288,299,307,310,317,336-340,358$.

180 „Veseli me skupština, koju je sazvao jedan od najvećih mučenika proganjanog istarskog naroda (misli na župnika Červara, op. Ž. K.). (...) Uza sve to stoji danas istarski puk pred teškim kušnjama. Iz naše vlastite sredine podigoše se ljudi, koji hoće da razbiju slogu i jedinstvo onoga pučanstva, koje uzdržava radom svojih žuljeva gospodarsko i narodno življenje u Istri. Duh kapitalizma i bankirstva htio bi razbiti vrste naših seljaka i radnika. To moramo zapriječiti. Ići moramo u boj za njegove i socijalne i gospodarske pravice te mu oživotvoriti tvrdu i čvrstu, jedinstvenu organizaciju. Ako bude naše pučanstvo gospodarski uništeno, bit će uništen takodjer njegov narodni opstanak. Narod, koji izgubi svoju gospodarsku samostalnost, zapisan je u knjigu smrti. Vi ste se, veleč. gosp. župniče, postavili na stranu onoga pučanstva, iz kojega ste izašli i s kojim ste u cijelom svom životu radili i trpjeli. Stoga i jedinstvo radnoga pučanstva neka živi i neka postane za Istru ugaoni stup naše narodne moći i naše narodne kulture. Nijedna sila na svijetu ne će dijeliti goričkog seljaka i radnika od njegovog istarskog brata, s kojim hoće da radi i da se bori do konačne pobjede.“ „Glavna skupština 'Političkog društva za Hrvate i Slovence u Istri’ u Trstu. Historija se ponavlja: Istra hoće da se opet podigne na vlastite noge.“, Pučki prijatelj, 19. listopada 1922.

181 Jedan od voditelja Zadružnoga saveza u Gorici. Radetić, Istra pod Italijom 1918-1943, 120.

182 O Liberatu Slokoviću, župniku u Sv. Petru u Šumi: Petar Pahović, „Liberat Sloković plovan supetarski“, Istarska Danica 1980., Pazin 1979., 95-99; Mladenka Hammer, „Članovi uprave Hrvatske čitaonice i drugih hrvatskih društava u Pazinu na kraju 19. i početkom 20. stoljeća (Popis)“, Hrvatska čitaonica u Pazinu, 316 ; Slaven Bertoša, „Sv. Petar u Šumi u novom vijeku (17.-19. stoljeća)“, Croatica Christiana periodica, 39, 76, 2015., 72; Klen, Neki dokumenti o svećenstvu u Istri, 17, 36, 42; Milanović, Hrvatski narodni preporod u Istri, II, 310, 527; isti, Istra u 20. stoljeću, 1, 24, 95, 124; Klaić, „Nacionalni pokret istarskih Hrvata i Slovenaca“, 53-54; isti, „Prilog proučavanju hrvatskih kreditnih zadruga“, 237, 245. 
parlamentu Virgilij Šček prikazao je „politički položaj u Italiji uopće i kod nas posebice“, preporučivši u prvom redu gospodarsku organizaciju i takvu politiku kojom će se nastojati pomoći seljaštvu.

Donesena je rezolucija kojom se Političko društvo za Hrvate i Slovence u Istri smatra „organizacijom narodne stranke u Istri“, a Pučki prijatelj njezinim glasilom. U jednoj rezoluciji skupštinari pozdravljaju svog „expredsjednika“ Božu Milanovića, istarske prvake Dinka Trinajstića, Matka Laginju, Vjekoslava Spinčića i sve ostale nacionalne radnike „koji su si u radu za naš narod u Istri stekli zasluga“.183

Nakon prihvaćanja rezolucija ${ }^{184}$ odlučilo se da novoizabrani odbor Političkoga društva uputi pozdrav Političkom društvu Edinost u Gorici i Političkom društvu Edinost u Trstu. Oba se društva smatraju bratskim društvima te će se stupiti u dogovor s njima da se kao najviša instanca za sva tri društva osnuje Narodno vijeće. ${ }^{185}$

Božo Milanović je priznao da je zbog promidžbe među hrvatskim i slovenskim pukom skupština u Pučkom prïatelju prikazana u „življim bojama“. Javno je djelovanje u Istri zbog fašističkoga pritiska bilo teško ostvarivo, ali je sama skupština pokazala da su se nacionalni radnici u Istri posve podijelili u dvije skupine. Obje su skupine bile nacionalne i nastupale su zajednički pred talijanskim vlastima i u javnosti. I jedna i druga bile su načelno demokratske, premda se, prema Milanoviću, demokratizam kršćanskih socijalista više isticao i to većom ljubavi i skrbi za seljački i radnički stalež. U gospodarskom i društvenom pogledu ni jedni ni drugi nisu imali „potanje izrađeni program“, ali je nacionalno-liberalna skupina više prihvaćala kapitalističke, a druga socijalne ideje. Glavna je idejna razlika bila u tome da je jedna bila načelno kršćanska, a druga bez određenoga svjetonazora. Napominje da to ne znači da su svi članovi prve skupine bili dobri kršćani, kao ni da su pristalice druge skupine svi bili zli kršćani ili čak protiv kršćanstva. Iznimaka je bilo s obje strane jer se nisu priključivali samo iz načelnih, nego iz osobnih razloga. ${ }^{186}$

183 „Glavna skupština 'Političkog društva za Hrvate i Slovence u Istri’ u Trstu. Historija se ponavlja: Istra hoće da se opet podigne na vlastite noge.“, Pučki prijatelj, 19. listopada 1922.

184 O donesenim rezolucijama i u Pučkom prijatelju od 2. studenoga 1922.

185 Završetak teksta u Pučkom prijatelju bio je optimističan: „Svima je odsijevala radost sa lica, jer su svi osjećali, da se je onoga dana položio prvi temelj iza rata za solidni i sistematični rad oko preporoda našega naroda u Istri u narodnom, gospodarskom i socialnom pogledu.“ „Glavna skupština 'Političkog društva za Hrvate i Slovence u Istri' u Trstu. Historija se ponavlja: Istra hoće da se opet podigne na vlastite noge.“, Pučki prijatelj, 19. listopada 1922. 
Odvajanje od Političkoga društva Edinost skupštinom od 12. listopada 1922. istarski socijalni kršćani objašnjavaju istim prilikama koje su dovele na početku XX. stoljeća do utemeljenja Političkoga društva za Hrvate i Slovence u Istri. Kao i na prijelomu stoljeća, kada su istarski narodnjaci naglašavali nedovoljan i nedjelotvoran rad Edinosti za Istru, tako su i tada kršćanski socijalisti isticali slab rad i slabu aktivnost Edinosti za Istru, zbog čega postoji čitav niz neriješenih pitanja koja se tiču istarskoga stanovništva, od političkih i gospodarskih do kulturnih. Smatraju da je, uz fašističko nasilje, nedovoljan i neuspješan rad Edinosti nakon Svjetskoga rata odgovoran za položaj istarskoga stanovništva. Ipak je sveukupna društvena situacija u poslijeratnom vremenu u talijanskoj državi, pa tako i u Istri, bila daleko složenija i bremenitija u odnosu na austrijsko vrijeme utemeljenja Političkoga društva 1902. Na prijelomu stoljeća radilo se o zastoju nacionalnoga pokreta istarskih Hrvata i Slovenaca, ali je on prevladan, da bi se u godinama neposredno pred Svjetski rat snažnije izrazile idejne razlike unutar nacionalnih redova, no ipak se jedinstvo Hrvatsko-slovenske narodne stranke održalo. Nakon rata politička sloga je bila dominantna jer je nacionalna egzistencija dolazila u pitanje, a gospodarska kriza istarskoga sela, gdje su prevladavali momenti poput poreznoga opterećenja i propadanja zadrugarstva, sve je više prisutna. Seljaštvo koje je u austrijskom razdoblju bilo temelj na koji se oslanjalo nacionalno vodstvo, sada stradava, njegov opstanak i njegova egzistencija bili su ugroženi. Socijalni su kršćani bili protivnici ekonomskoga liberalizma i banaka, što se jasno primjećuje u istupu Šime Červara i u pismu Engelberta Besednjaka. Taj će moment u kritičkom pristupu socijalnih kršćana u godinama koje su uslijedile sve više jačati, kako je stradavalo i bilo uništavano zadrugarstvo utemeljeno u austrijskom vremenu. Gospodarsko djelovanje istarskih kršćanskih socijalista, ali i ne samo u tom smislu, bit će povezano s djelovanjem goričkih javnih radnika pa će na prostoru Istre rad pokretati i širiti Zadružni savez iz Gorice. Naravno, nije djelovala samo ta institucija već je svoju aktivnost provodio i Zadružni savez iz Trsta. ${ }^{187}$ Za pokretanje radničkih i seljačkih saveza, o čemu je bilo govora na skupštini, zalagali su se Goričani pa će tako i istarski socijalni kršćani kroz nekoliko godina pokrenuti Seljački savez kao strukovnu organizaciju, ali kako je pitanje javnoga djelovanja pod fašizmom

187 Josip Agneletto, „Zadružna Zveza v Trstu“, Jadranski almanah za leto 1924., ur. Janko Kralj, Trst 1923., $65-$ 68; David Doktorič, „Zadružna Zveza v Gorici“, isto, 68-72; Josip Rustja, „Razvoj zadružništva v Julijski krajini“, Jadranski almanah za leto 1925-1930, 58-71. 
bilo teško ostvarivo, i ta će institucija imati problem s radom i opstankom.

Jedan od vidova djelovanja u tom smjeru bio je onaj preko tiska, gdje su se seljacima davale razne gospodarske upute, pa i pravni savjeti, kao npr. kako napisati molbu ili kamo je treba uputiti. U Gorici je tako djelovao Josip Bitežnik, koji je vodio „Ljudsko tajništvo“. U Istri će sličan način djelovanja ići preko „Razumnoga gospodara“, mjesečnoga priloga Pučkoga prïatelja, koji je započeo izlaziti prije Svjetskoga rata, a u poratnim je godinama neredovito objavljivan. ${ }^{188}$ Prilog će promicati ideju seljačkoga saveza, objavljivati pitanja seljaka i odgovore na njih, donositi razne gospodarske upute, ali i davati pravne savjete. Liberalno vodstvo Edinosti u Trstu socijalni kršćani smatrali su bliskim kapitalu i bankama pa će tako u narednim godinama kritizirati u svom tisku nepravedne visoke zarade i visoke kamate u bankarskom poslovanju, suprotstavljajući bankama djelovanje zadružnih organizacija, čiji se rad želi obnoviti i dalje razvijati, uzimajući u obzir i prikazujući primjere zadružnoga djelovanja na socijalno-kršćanskim načelima u europskim zemljama. ${ }^{189}$ Međutim, povijest će u tom smislu krenuti nekim drugim putom no što su promišljali kršćanski socijalisti, kao i drugim putom no što su promišljali o gospodarskoj problematici istarski nacionalni radnici drugih idejnih opredjeljenja.

Među socijalnim kršćanima okupljenim oko Tiskovnoga društva u Pazinu i Pučkoga prijatelja bilo je i onih koji su bili pripadnici Političkoga društva za Hrvate i Slovence u Istri od samoga njegova utemeljenja 1902. Tako su istarski svećenici koji su bili članovi Političkoga društva na početku XX. st. i podupirali njegov rad prije rata bili aktivni u namjerama obnavljanja njegova rada u talijanskoj državi. Pozivanjem na Trinajstića, Laginju i Spinčića u jednoj od rezolucija donesenih na skupštini 12. listopada 1922., istarski kršćanski socijalisti željeli su naglasiti da su upravo oni nasljednici istarskih narodnjaka i njihova predratnog djelovanja.

188 Nakon što je 1924. obnovljen Pučki prijatelj, s 1925. započinje peta godina izlaženja „Razumnoga gospodara“ i njegovih 12 brojeva. Iduća 1926. je šesta godina izlaženja i tiskano je 12 brojeva (za studeni i prosinac dvobroj). Naredna 1927. je sedma godina izlaženja i tiskano je šest brojeva (za siječanj i veljaču dvobroj). Posljednja 1928. je osma godina izlaženja i tiskana su tri broja (za veljaču i ožujak dvobroj). France Bevk - Lavo Čermelj, „Periodne publikacije“, Luč, Poljudno-znanstveni zbornik, IV, zbral Lavo Čermelj, Trst 1929., 76.

189 Npr. članak: J., „Kršćanska seljačka gospodarska organizacija u Belgiji“, Danica, Koledar za prostu godinu 1925., Trst 1924., 93-96. 
Premda je na skupštini (po izvješćivanju Pučkoga prïatelja) raspoloženje oko pokretanja samostalne aktivnosti bilo optimistično, ipak je zbivanje otišlo u drugom smjeru jer će fašističko nasilje i pogotovo dolazak fašističke stranke na vlast 28. listopada 1922., ubrzo nakon održane skupštine, suprotstavljenim stranama biti pokazatelj da će se položaj hrvatske i slovenske manjine još više pogoršati. Upućivalo je to obje strane na zbližavanje i dogovaranje. Inicijative za pregovore dolazile su s jedne i druge strane. Desetak dana nakon što je Mussolini preuzeo vlast, 9. studenoga 1922. Stanger iz Opatije između ostaloga piše Mirku Vratoviću: „Političko društvo za Hrvate i Slovence ima prestati, a mjesto njega, ako već treba da se rastavimo od Trsta za volju mira, što ja ne odobravam, ima se ustrojiti novo političko društvo 'Edinost za Istru'““ Iveša javlja Stangeru 7. prosinca 1922. da je „klerikalna struja“ ovlastila za pregovore Milanovića, Brajšu i Kraševca. Predsjednik Pododbora Edinosti za Istru Vratović ne želi sudjelovati u pregovorima, ali izjavljuje da će prihvatiti sporazum ako bude dobar. U pregovorima je došlo do kompromisnoga sporazuma, ali stvarne razlike u nazorima za vođenje politike građanskih grupa u Istri, konstatira Bratulić, i dalje su izbijale u javnost. Za ilustraciju stanja u odnosima navodi dio Ivešina pisma upućena Stangeru 11. siječnja 1923.: „Danas je Vratović otišao na sjednicu Narodnog vijeća u Goricu. - Danas je izašao novi list 'Istarska riječ““ (...) „Danas je isto tako izašla i 'Istra', koja nije ništa drugo nego 'Pučki Prijatelj'. Kakav je to sporazum, kad oni nastavljaju sa listom, koji izlazi isto u četvrtak kao i Pučki. Ne razumijem ništa. “190

Pučki prïatelj od 28. prosinca 1922. piše da se potreba za sporazumom „dviju struja“ povećala „pritiskom onih, koji idu za tim, da našu narodnost što prije istrijebe iz Istre“, očito misleći na dolazak fašista na vlast u Rimu, koji je uslijedio ubrzo nakon obnavljanja Političkoga društva za Hrvate i Slovence u Istri. Glasilo javlja da je sklopljen sporazum između Političkoga društva za Hrvate i Slovence u Istri i Istarskoga pododbora Političkoga društva Edinost u Trstu. Sporazum se temeljio na načelu potpune jednakopravnosti obje struje. Utvrđeno je da se umjesto dotadašnjih političkih društava i novinskih glasila utemelji za Istru nova zajednička politička organizacija i novo zajedničko političko glasilo. Prestaju izlaziti Pučki prijatelj i Stara naša sloga, a umjesto njih izdavat će jedan zajednički konzorcij od četiri osobe novi politički tjednik za Istru, Istarsku riječ. Tiskovno društvo u 
Pazinu izdavat će umjesto Pučkoga prïatelja novi nepolitički, kulturno-gospodarski list pod nazivom Istra. ${ }^{191}$

Krajem prosinca 1922. dogovoreno je samostalno društvo Edinost, odvojeno od tršćanskoga društva, u čijem su vodstvu bile jednakopravno zastupljene obje struje. ${ }^{192}$ Međutim, sporazum će biti kratkotrajan jer će se idejna razilaženja i suprotstavljeni pogledi samo pojačavati, a radikalizaciji u stavovima posebno će pridonijeti problematika vezana za Jadransku banku i zamjenu nekadašnjih austro-ugarskih kruna za lire. ${ }^{193}$ Zbog toga će se početkom 1924. ponovno pokrenuti Pučki prijatelj i nastojati obnoviti Političko društvo za Hrvate i Slovence u Istri.

\section{Zaključak}

Na prijelazu iz XIX. u XX. stoljeće nacionalni pokret istarskih Hrvata i Slovenaca ulazi u razdoblje stagnacije, čega su pokazatelj rezultati državnih, zemaljskih i općinskih izbora, ali i socijalno-gospodarski položaj seljaštva, koje je bilo glavni oslonac nacionalnom vodstvu pokreta. Istodobno su se u Markgrofoviji Istri odvijale važne aktivnosti istarskih narodnjaka na pravno-političkom, gospodarskom i kulturnom području, koje će voditi prevladavanju poteškoća. U to vrijeme utemeljit će se politička organizacija istarskih narodnjaka - Političko društvo za Hrvate i Slovence u Istri sa sjedištem u Pazinu 1902. - ali i gospodarska organizacija - Gospodarska sveza za Istru u Puli 1903. Gospodarske organizacije, pogotovo značajne posujilnice, oslobađale su seljaštvo zaduženosti i stvarale uvjete za njegovu gospodarsku neovisnost te mu omogućile izražavanje vlastite političke volje na općinskim, zemaljskim i državnim izborima. Utemeljenje i djelovanje političke organizacije istarskih narodnjaka, utemeljenje i djelovanje zadružnih organizacija te rad kulturnih institucija, uz neizostavnu demokratizaciju izbornoga zakonodavstva za bečki parlament, kada je na temelju općega izbornog prava glasa Hrvatsko-slovenska narodna stranka u Istri na državnim izborima 1907. ostvarila uspjeh, poteškoće u razvoju pokreta na prijelomu stoljeća bile su prevladane.

191 „Našim pretplatnicima i našemu narodu. Na rastanku s 'Pučkim Prijateljem'.“, Pučki prijatelj, 28. prosinca 1922.

192 Kacin-Wohinz, Narodnoobrambno gibanje primorskih Slovencev v letih 1921-1928, I, 170-171.

193 Mira Kolar-Dimitrijević, „Kratak pregled povijesti tršćanske Jadranske banke i njezin utjecaj na razvoj hrvatskog gospodarstva od 1905. do 1941. godine“, Talijanska uprava na hrvatskom prostoru i egzodus Hrvata (1918.-1943.), Zbornik, gl. i odg. urednik Marino Manin, Zagreb 2001., 563-593; Željko Klaić, „Novčane prilike Gospodarske sveze za Istru (1918.-1924.)“, Vjesnik istarskog arhiva, 4-5, 1998., 92-99; Kacin-Wohinz, Narodnoobrambno gibanje primorskih Slovencev v letih 1921-1928, I, 126-127, II, 340-341. 
Međutim, težnje će narodnjaka temeljem izbornih rezultata 1907. ići i prema Istarskom saboru, prema reformi zemaljskoga izbornog reda, koji bi im omogućio veći utjecaj u autonomnim upravnim tijelima pokrajine, pa i ostvarenju ravnopravnosti s talijanskim liberalima. Oni su pod pritiskom bečke vlade, kao i hrvatski narodnjaci, u ožujku 1908. prihvatili djelomičnu demokratizaciju zemaljskoga izbornog sustava, a novom je izbornom geometrijom talijanskim liberalima u Saboru i dalje bila osigurana prevlast. „Politika narodnoga mira“ inaugurirana od bečke vlade nije ostvarila očekivano i unutar Političkoga društva za Hrvate i Slovence u Istri dolazi do previranja te izraženoga nezadovoljstva, pogotovo kod pripadnika mlađega naraštaja javnih radnika jer nije postignuta ravnopravnost $\mathrm{s}$ talijanskim liberalima $\mathrm{u}$ autonomnim upravnim tijelima pokrajine. Nezadovoljstvo novom izbornom reformom unutar Narodne stranke nije pogodovalo radu političke organizacije. Unatoč daljnjim pregovorima nakon 1908. s predstavnicima talijanskih liberala o raznim pitanjima, ravnopravnost Hrvata i Slovenaca, koja je bila cilj Hrvatsko-slovenske narodne stranke, odnosno Političkoga društva za Hrvate i Slovence u Istri, nije postignuta. Premda se idejna razilaženja unutar nacionalnoga pokreta istarskih Hrvata i Slovenaca javljaju već na prijelomu stoljeća, suprotstavljanja u nazorima između nacionalno-liberalne i kršćansko-socijalne struje snažnije se izražavaju u godinama neposredno pred Svjetski rat pa su i te razlike unutar Narodne stranke, odnosno Političkoga društva za Hrvate i Slovence u Istri, usporavale rad. Ipak, razlike su prevladane i nova društvena pravila iz 1913. utvrđuju demokratizaciju Političkoga društva. Tijekom rata Političko društvo nije moglo djelovati, premda se spominje.

Nakon dolaska Istre, Trsta i Goričke u sastav Kraljevine Italije, budući da je sama egzistencija hrvatskoga i slovenskoga naroda u tim krajevima došla u pitanje, ostvarenje političke sloge bilo je dominantnom zadaćom unutar slovenskih i hrvatskih građanskih redova. Aktivnost Političkoga društva Edinost iz Trsta kreće prema obnavljanju i objedinjavanju društvenoga rada te pokretanja jedinstvenoga političkog djelovanja na prostoru koji se našao pod Italijom. Razlike u nazorima između liberala i kršćanskih socijalista su se u jedinstvenom društvu zadržale, ali oni su se zbog sveukupnih nacionalnih interesa povezali, svakako i na primjeru zajedničkoga nastupanja na državnim izborima 1921. Ipak, bez političkoga i gospodarsko-socijalnoga programa Političkoga društva Edinost nije bilo moguće uspostaviti snažnu djelotvornu organizaciju. Već su se sredinom 1920. s tim u vezi pojavili 
u okviru Političkoga društva Edinost pokazatelji idejnih razmimoilaženja, suprotnosti između kršćansko-socijalne i nacionalno-liberalne struje. Slovenski su svećenici u ime socijalnih kršćana na sjednici Odbora Edinosti 10. lipnja 1920. predložili program na kojem bi trebalo raditi. Društvo Edinost bilo je suglasno sa širenjem kršćansko-socijalnih programskih načela, ali ih nije priznalo kao društveni program jer bi načela mogla utjecati na podjele.

I glasilo istarskih socijalnih kršćana Pučki prïjatelj, koje je početkom rujna 1919. ponovno započelo izlaziti, težilo je ostvarenju političke sloge. Izdavači i uredništvo polazili su od toga da je Pučki prijatelj tada jedino hrvatsko istarsko glasilo i da izlazi u teško doba za hrvatski narod u Istri. Zato je glasilo uređivano nestranački, ne vodeći računa o nekadašnjoj diobi na dvije političke struje. Uredniku glasila preporučeno je 1919. izbjegavati pisanje koje bi izazvalo sukob s nacionalno-liberalnom strujom, a uoči državnih izbora 1921. kršćanski socijalisti podržali su predstavnike te struje Josipa Wilfana i Uliksu Stangera kao istarske kandidate.

Međutim, i Pučki prijatelj započet će izražavati nezadovoljstvo zbog nepostojanja sustavnoga i organiziranoga rada, naglašavajući izraženu apatičnost zbog međusobnoga nepovjerenja u zajednički rad. Nezadovoljstvo izražava upravo u trenutku definitivnoga priključenja Julijske krajine početkom 1921. Italiji, naglašavajući potrebu reorganizacije djelovanja i rada. Kao što su gorički kršćanski socijalisti izražavali nezadovoljstvo rezultatima državnih izbora u Trstu i Istri 15. svibnja 1921., tako je u reagiranju bio oštar i Pučki prïatelj, naglašavajući nepostojanje izbornoga programa. Osvrtao se i na istupanje Ščeka i Wilfana. Prvi je zahtijevao izričito socijalno-gospodarski program, dok se drugi pozivao na „program konkretnih stečevina“ u prošlosti i na historijsku nadstranačku misiju Političkoga društva Edinost, označujući zahtjev izričitoga socijalno-gospodarskoga programa strančarskim. Šček, koji je pokretao programska pitanja, tražio je javnu raspravu uza sudjelovanje naroda, a ne samo u najužem krugu Političkoga društva Edinost, a Wilfan je zauzeo stav da se o takvim pitanjima ne raspravlja javno, već jedino u okviru Političkoga društva.

Upravo su rezultati državnih izbora bili poticaj istarskim kršćanskim socijalistima da krenu sa samostalnijim i aktivnijim radom. U tom smislu Božo Milanović, jedan od četiri Istrana u Odboru Edinosti, pokreće inicijativu za osnivanje Istarskoga pododbora Političkoga društva Edinost, koji bi trebao provoditi samostalniji i intenzivniji rad za Istru. Pododbor je usta- 
novljen u srpnju 1921., a za njegova predsjednika izabran je Milanović, koji je sazvao burnu skupštinu u Kozini 10. srpnja 1922.

U srpnju i rujnu 1921. u Pučkom prijatelju izlaze Milanovićevi članci o pojmu, smislu, značenju i djelovanju institucije organizacije, kakvih sve tipova organizacija ima te kakav duh mora u organizaciji vladati, zatim kako se vode sjednice i skupštine te uopće kako zamišlja rad i aktivnost Pododbora. Stavlja u prvi plan organizaciju kada je riječ o postizanju nacionalnopolitičkih, gospodarskih i kulturnih ciljeva. Naglašavao je važnost izgradnje političke, gospodarske, prosvjetne i kulturne organizacije. Premda se ne može govoriti o nekom cjelovitom programu - a niti je prostor u tisku to omogućavao - očite su programske smjernice za rad i djelovanje. One upućuju na nastavljanje rada i djelovanja istarskih narodnjaka kakvo je bilo na prijelomu stoljeća, kao i u vremenu neposredno pred Svjetski rat, ali upućuju i na djelovanje kršćanskih socijalista u vremenu pred rat. Iako su se idejne razlike - suprotstavljeni nazori unutar Političkoga društva za Hrvate i Slovence u Istri - pred rat izrazile, Hrvatsko-slovenska narodna stranka je uspjela sačuvati jedinstvo. Milanović je smatrao da se s obzirom na nove, teže okolnosti, nacionalni predstavnici trebaju dogovoriti i složiti. Taj sporazum neće biti teško ostvariti ako se shvati da opreke u svjetonazorima - osobito starijih - nacionalnih prvaka u Istri nisu nepremostive. On piše u vrijeme kada ne postoje javni pokazatelji idejnih neslaganja unutar Istarskoga pododbora Edinosti, niti se u javnosti govori da bi se javna neslaganja mogla uopće pojaviti ili obnoviti. Međutim, narodnjaštvo istarskih kršćanskih socijalista na čelu s Milanovićem - koje je po njima uključivalo i vjersku komponentu - samo nešto manje od godine dana poslije, na burnoj skupštini u Kozini 10. srpnja 1922. naći će se pod snažnim napadima i izraženom kritikom. Premda su postojale idejne razlike u nazorima, one su ostale u pozadini - na početku se Milanovićeva predsjedavanja Istarskim pododborom nisu javno izrazile, iako su po njegovu svjedočenju u osobnim kontaktima bile vidljive, osobito s obzirom na način rada i uređivanja glasila. Svjetonazorske su se razlike u javnosti prije pojavile na nekim drugim razinama. Primjerice, bio je to sukob u nazorima povodom izdavanja koledara Istranin za 1922. Tiskovnoga društva u Pazinu, uz suprotstavljene stavove i poglede iznesene u Učiteljskom listu. Stavovi iz te polemike u mnogome će se zamjećivati, ali i radikalizirati pogledima iznesenim na skupštini u Kozini 10. srpnja 1922. 
Polemika između Pučkoga prïatelja i Učiteljskoga lista, koja se protegnula kroz nekoliko mjeseci, morala je imati utjecaja na istarske hrvatskoslovenske političke krugove, pa i pospješiti obnavljanje predratnih idejnih razmimoilaženja. Povrh toga, ona će se odvijati u daleko većim poslijeratnim društvenim suprotnostima unutar talijanske države, kojoj je pripadala istarska sredina, u odnosu na suprotnosti u predratnoj Austro-Ugarskoj. Te će suprotnosti potaknuti nekadašnje njihove idejne razlike i njihovo daljnje radikaliziranje. Idejni su se sukobi unutar istarskih krugova zbog fašističkoga pritiska privremeno morali obustaviti jer će fašisti krajem listopada 1922. doći na vlast pa će to i jednu i drugu stranu upućivati na dogovor, premda razlike stvarno nikada nisu prevladane. Treba reći da je težnja za objedinjavanjem rada uvijek postojala, ali istodobno su stalna suprotstavljanja onemogućavala da se ono i ostvari. To ne znači da pripadnici jedne i druge skupine nisu međusobno razgovarali i održavali veze.

Fašistička zabrana rada i djelovanja hrvatskih i slovenskih institucija krajem dvadesetih godina, kada su gotovo svi nacionalni radnici kršćansko-socijalne i nacionalno-liberalne skupine bili prisiljeni na emigraciju, u krajnosti znači i prestanak idejnih sukoba unutar istarskih krugova na terenu u pokrajini.

\section{Sažetak}

Nakon dolaska Istre, Trsta i Goričke u sastav Kraljevine Italije jer je sam opstanak hrvatskoga i slovenskoga naroda u tim krajevima došao u pitanje, ostvarenje političke sloge bilo je dominantno pitanje unutar slovenskih i hrvatskih političkih redova. Aktivnost Političkoga društva Edinost iz Trsta kreće prema pokretanju jedinstvenoga političkog djelovanja na prostoru koji se našao pod Italijom. I nakon što su se povezali zbog općenacionalnih interesa, razlike u nazorima između liberala i kršćanskih socijalista su se u jedinstvenom društvu zadržale. I glasilo istarskih kršćanskih socijalista Pučki prijatelj, koje je početkom rujna 1919. ponovno započelo izlaziti, težilo je ostvarenju političke sloge. Uredniku lista preporučeno je 1919. izbjegavati pisanje koje bi izazvalo sukob s nacionalno-liberalnom strujom, a uoči državnih izbora 1921. kršćanski socijalisti podržali su pripadnike te struje kao istarske kandidate. No, bez političkoga i gospodarsko-socijalnoga programa nije bilo moguće uspostaviti snažnu djelotvornu organizaciju.

Već su sredinom 1920. gorički svećenici predložili program temeljen na kršćansko-socijalnim načelima. Društvo Edinost bilo je suglasno sa širenjem tih načela, ali ih nije priznalo kao društveni program jer bi takva načela stvarala podjele. Međutim, 
i Pučki prijatelj započet će izražavati nezadovoljstvo zbog nepostojanja sustavnoga i organiziranoga rada. List je nezadovoljstvo izražavao upravo u vrijeme definitivnoga priključenja Julijske krajine početkom 1921. Italiji, naglašavajući potrebu reorganizacije djelovanja i rada. Nakon državnih izbora u svibnju 1921., socijalni su kršćani javno kritizirali vodstvo Edinosti da je krivo za slabe izborne rezultate u Istri i Trstu, problematizirajući program rada Političkoga društva. Bio je oštar i Pučki prijatelj, kritizirajući i on u prvom redu izborni program. Stoga jedinstvenoga nacrta za smisleni rad na političkom, kulturnim, socijalnom i gospodarskom području nije bilo. Upravo su izborni rezultati bili poticaj istarskim kršćanskim socijalistima u promišljanju da i oni poput Goričana krenu sa samostalnijim i aktivnijim radom. U srpnju 1921. utemeljen je u Kozini Istarski pododbor Političkoga društva Edinost, a za predsjednika je bio imenovan Božo Milanović, koji će to biti do sredine srpnja iduće godine. U početku Milanovićeva predsjedavanja Pododborom nema u javnosti pokazatelja idejnih razilaženja, osim u osobnim kontaktima. Tek kada je Tiskovno društvo u Pazinu izdalo koledar Istranin za 1922., polemika između Učiteljskoga lista i Pučkoga prijatelja ukazala je javnosti na idejna razilaženja, a skupština Istarskoga pododbora održana u Kozini 10. srpnja 1922. te reakcije u glasilima nakon nje pokazuju da je slijed zbivanja vodio prema raskolu. Pokušaj obnove rada Političkoga društva za Hrvate i Slovence u Istri bio je kratkotrajan: dolazak fašista na vlast sukobljene je strane primorao na dogovor, koji međutim nije dugo potrajao jer se idejna razilaženja i sukobi nisu mogli prevladati.

\section{L'assemblea del 10 luglio 1922 della Società politica Edinost a Cosina e l'intento dell'ottobre 1922 di ripristinare l'attività della Società politica per Croati e Sloveni in Istria}

\section{Riassunto}

Dato che in seguito all'annessione dell'Istria, Trieste e Gorizia al Regno d'Italia era stata messa a repentaglio l'esistenza della popolazione croata e slovena di questi territori, la preoccupazione dominante nelle file politiche slovene e croate fu il raggiungimento di un'intesa politica. Gli sforzi della Società politica Edinost di Trieste si mossero verso l'avviamento di un'attività politica unitaria nel territorio assoggettato all'Italia. Pur essendosi raccolte attorno ad un interesse nazionale comune, le visioni dei liberali e dei socialisti cristiani continuarono a differire all'interno della società unificata. Anche il giornale dei socialisti cristiani istriani Pučki prijatelj, che tornò alle stampe agli inizi di settembre 1919, sostenne la realizzazione dell'unità politica. Nel 1919 fu consigliato all'editore del giornale di evitare testi che provocassero scontri con la corrente nazional-liberale e, in vista delle elezioni statali del 1921, i socialisti cristiani appoggiarono i rappresentanti di tale corrente in qualità di candidati istriani. Però, senza un programma economico-sociale, non sarebbe stato possibile stabilire un'organizzazione solida ed efficace.

Già verso la metà del 1920 il clero goriziano aveva proposto un programma fondato su principi cristiano-sociali. La società Edinost condivideva la diffusione di tali principi, ma non li riconobbe quale programma della società perché avrebbero 
creato divergenze. Tuttavia, anche Pučki prijatelj iniziò a manifestare la propria insoddisfazione per l'inesistenza di un'attività sistematica ed organizzata. Il giornale manifestava la propria insoddisfazione proprio nel momento dell'annessione definitiva della Venezia Giulia all'Italia, agli inizi del 1921, enfatizzando la necessità di riorganizzare le attività e l'operato. Dopo le elezioni statali del maggio 1921, i socialisti cristiani criticarono pubblicamente la dirigenza di Edinost imputandole i deludenti risultati elettorali in Istria e a Trieste, e mettendo in questione il programma operativo della Società politica. Fu arduo anche Pučki prijatelj, criticando, innanzitutto, il programma elettorale. Era quindi inesistente una linea unitaria volta all'attuazione di un piano d'azione sensato nel campo politico, culturale, sociale ed economico. Furono proprio i risultati elettorali a spronare i socialisti cristiani istriani a prendere in considerazione l'avviamento di un'attività più indipendente e dinamica, come avevano già fatto i goriziani. Nel luglio 1921, fu costituito a Cosina il Sottocomitato istriano della Società politica Edinost, attribuendo l'incarico di presidente a Božo Milanović, che ricoprirà tale ruolo fino a luglio dell'anno successivo. Nel periodo iniziale della presidenza di Milanović nel Sottocomitato, non ci furono manifestazioni pubbliche di differimenti tra idee, tranne nei contatti personali. Soltanto dopo la pubblicazione del calendario Istranin per il 1922 da parte della Tipografia di Pisino, la polemica tra Učiteljski list e Pučki prijatelj rivela una discordanza di opinioni e l'assemblea del Sottocomitato istriano tenutasi a Cosina il 10 luglio 1922 e le conseguenti reazioni pubblicate nei giornali indicano che lo svolgimento della situazione portava verso una disgregazione. Un tentativo di ripristino delle attività della Società politica per croati e sloveni in Istria fu di breve durata: l'ascesa al potere del fascismo costrinse le parti contrastanti a raggiungere un accordo, che non si mantenne però a lungo perché le divergenze e i conflitti non potevano essere superati.

\section{The Assembly of the Political Society 'Edinost' in Kozina on 10 July 1922 and the intention to renew the Political Society for Croats and Slovenes in Istria in October 1922}

\section{Abstract}

After the accession of Istria, Trieste and Gorizia to the Kingdom of Italy, since the very survival of the Croatian and Slovenian people in these parts came into question, the achievement of political harmony was a dominant issue within the Slovenian and Croatian political order. The activity of the Political Society 'Edinost' from Trieste moved towards the inception of a unified political activity in the area that had found itself under Italy. Even after they became allies because of national interests, the differences in views between liberals and Christian socialists persisted in the unified society. The newsletter of the Istrian Christian socialists, Pučki prijatelj (The People's Friend), which started being issued again at the beginning of September 1919, was striving for political concord. In 1919, the editor of the newspaper was advised to avoid writing which would initiate a conflict with the national-liberal movement, and on the eve of the 1921 state elections, the Christian socialists supported members of 
that movement as Istrian candidates. However, without a political and economic-social programme, it was not possible to establish a strong and effective organization.

As early as the mid-1920, Gorizian priests proposed a programme based on Christian-social principles. The Society 'Edinost' supported the dissemination of these principles, but did not acknowledge them as a social agenda because such principles would create divisions. However, Pučki prijatelj would also begin expressing dissatisfaction with the lack of systematic and organized work. The newspaper expressed its dissatisfaction at the time of the definitive annexation of the Venezia Giulia in early 1921 to Italy, emphasizing the need to reorganize its activities and work. After the May 1921 state elections, social leaders publicly criticized the leadership of 'Edinost' for poor election results in Istria and Trieste, reprimanding the political agenda of the Political Society. Pučki prijatelj was also harsh, primarily criticizing the election program. Therefore, there was no single blueprint for meaningful work in the political, cultural, social and economic field. The election results were the impulse for the Istrian Christian socialists to start thinking that they, like Gorizians, should start working more independently and actively. In July 1921, the Istrian subcommittee of the Political Society 'Edinost' was founded in Kozina, and Božo Milanović was appointed president, which is the position he held until mid-July the following year. At the beginning of Milanović's chairmanship of the Subcommittee, there were no indications of ideological differences in public, except in personal contacts. Only when the Pazin Press Society issued the Istranin calendar for $1922 \mathrm{did}$ the controversy between Učiteljski list (The Teacher's Gazette) and Pučki prijatelj show the public the existence of the conceptual differences; the Assembly of the Istrian Subcommittee held in Kozina on 10 July 1922, and the reactions in the newsletters, showed that the sequence events led to a schism. The attempt to renew the work of the Political Society for Croats and Slovenes in Istria was short-lived: the arrival of fascists compelled the conflicting party to reach an agreement, which, however, did not last long because the ideological differences and conflicts could not be overcome. 


\section{Prilog}
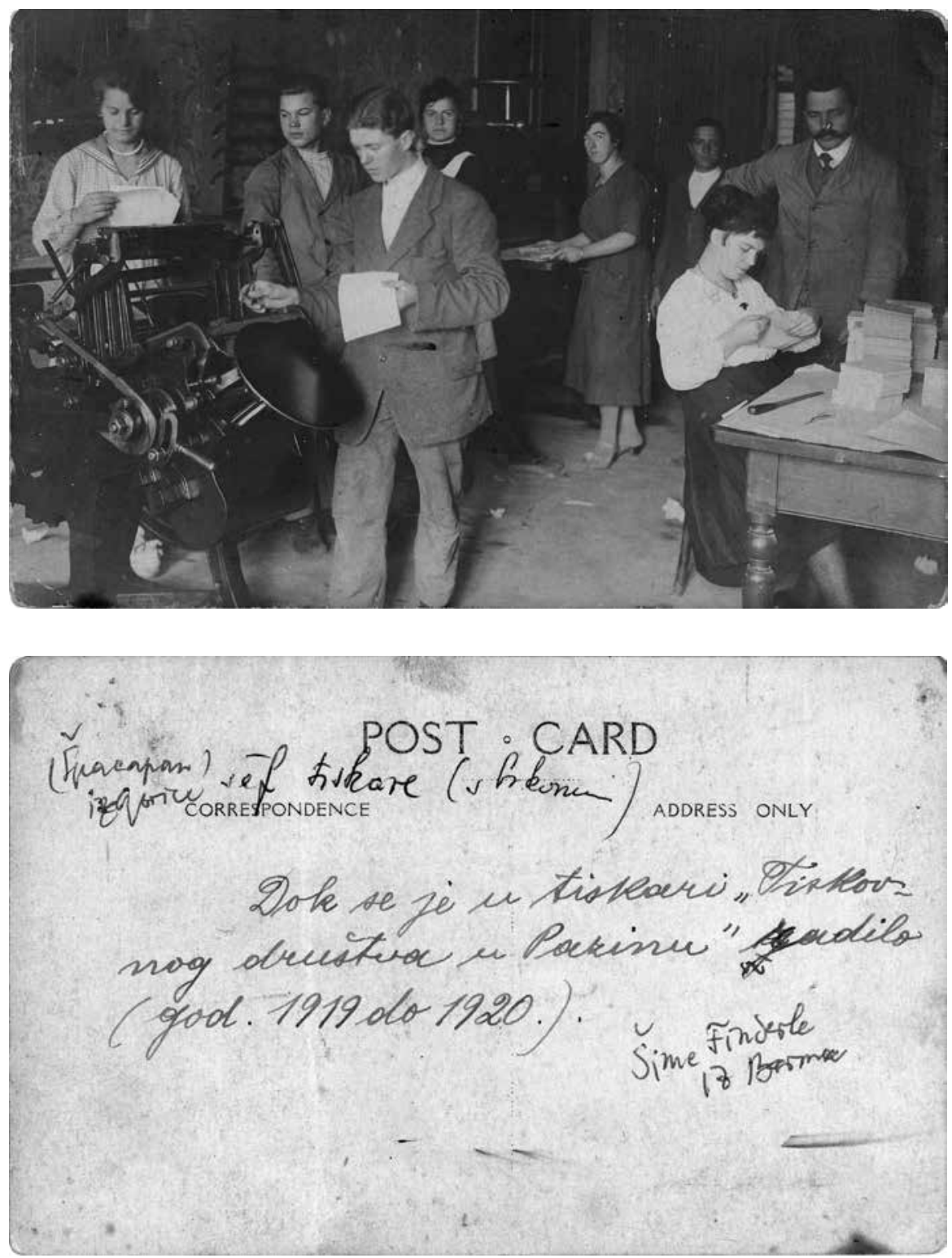

Sl. 1-2. Razglednica s djelatnicima Tiskare Tiskovnoga društva u Pazinu kada je od početka rujna 1919. pa do 15. srpnja 1920. u njoj izlazio Pučki prijatelj. Muškarac u prvom planu je Šime Finderle iz Berma, a muškarac s brkovima Ljudevit Špacapan iz Gorice, upravitelj Tiskare. 